\title{
LICENSED REACTOR NUCLEAR SAFETY CRITERIA APPLICABLE TO DOE REACTORS
}

Published: April 1991

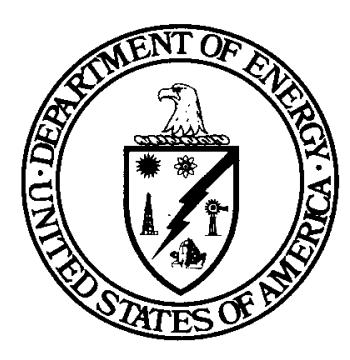

U.S. Department of Energy

Office of Nuclear Energy

Office of Nuclear Safety Policy and Standards

Washington, DC 20585 


\section{DISCLAIMER}

This report was prepared as an account of work sponsored by an agency of the United States Government. Neither the United States Government nor any agency Thereof, nor any of their employees, makes any warranty, express or implied, or assumes any legal liability or responsibility for the accuracy, completeness, or usefulness of any information, apparatus, product, or process disclosed, or represents that its use would not infringe privately owned rights. Reference herein to any specific commercial product, process, or service by trade name, trademark, manufacturer, or otherwise does not necessarily constitute or imply its endorsement, recommendation, or favoring by the United States Government or any agency thereof. The views and opinions of authors expressed herein do not necessarily state or reflect those of the United States Government or any agency thereof. 


\section{DISCLAIMER}

Portions of this document may be illegible in electronic image products. Images are produced from the best available original document. 
Mran 
Page

FOREWORD

vii

1. INTRODUCTION

$\begin{array}{lll}\text { 1.1 } & \text { Purpose } & 1-1 \\ 1.2 & \text { Sources of Criteria and Format } & 1-1 \\ 1.3 & \text { Deviations from Standard Format (RG 1.70) } & 1-3 \\ 1.4 & \text { Safety Analysis Report Criteria }\end{array}$

2. SITE CHARACTERIBTICB

2.1 Geography and Demography 2-1

2.2 Nearby Industrial, Transportation, and 2-2

2.3 Meteorology 2-3

2.4 Hydrologic Engineering 2-6

2.5 Geology, Seismology, and Geotechnical 2-10

Engineering

3. DESIGN OF BTRUCTURES, COMPONENTS, EQUIPMENT AND SYSTEMS

3.1 Conformance with NRC General Design Criteria 3-1

3.2 Classification of Structures, Components, 3-1 and systems

3.3 Wind and Tornado Loadings 3-3

3.4 Water Level (Flood) Design 3-4

3.5 Missile Protection 3-5

3.6 Protection Against Dynamic Effects 3-6

Associated with the Postulated Rupture of Piping

3.7 Seismic Design

3.8 Design of Category I structures 3-9

3.9 Mechanical systems and Components 3-13

3.10 Seismic and Dynamic Qualification of 3-16

Mechanical and Electrical Equipment

3.11 Environmental Design and Qualification 3-18

of Mechanical and Electrical Equipment

4. REACTOR

4.1 Summary Description 4-1

4.2 Fuel System Design. : 4-1

4.3 Nuclear Design 4-4

4.4 Thermal and Hydraulic Desicgn 4-5

4.5 Reactor Materials 4-5 


\section{CONTENTS (Continued)}

Page

4.6 Functional Design of Reactivity Control 4-7 systems

5. REACTOR COOLANT GYSTEM AND CONNECTED SYSTEMS

5.1 Summary Description

$5-1$

5.2 Integrity of Reactor Coolant Pressure

$5-1$ Boundary

5.3 Reactor Vessels

$5-5$

5.4 Component and Subsystem Design

$5-8$

6. ENGINEERED SAFETY FEATURES

6.1 Engineered Safety Feature Materials 6-1

6.2 Containment systems

$6-3$

6.3 Emergency Core Cooling System

6.4 Control Room Habitability system

6.5 Engineered Safety Feature (ESF) Atmosphere Cleanup system

6.6 Inservice Inspection of Class 2 and 3 Components

$6-9$

$6-11$

$6-13$

$6-15$

7. INSTRUMENTATION AND CONTROLS

7.1 Introduction - Identification of Safety- 7-1

Related systems and safety Criteria

7.2 Reactor Trip System

$7-4$

7.3 Engineered Safety Feature systems

7.4 Safe Shutdown Systems

7.5 Safety-Related Display Instrumentation

7.6 All other Instrumentation Systems Required for safety

7.7 Control Systems Not Required for Safety

$7-7$

$7-10$

$7-12$

$7-14$

$7-17$

8. ELECTRIC POWER

8.1 Introduction

8-1

8.2 Offsite Power system

$8-1$

8.3 Onsite Power Systems

$8-2$

9. AUXILIARY BYSTEMS

9.1 Fuel storage and Handling

$9-1$

9.2 Water Systems

$9-4$

9.3 Process Auxiliaries

$9-6$ 
CONTENTS (Contjinued)

Page

9.4 Air Conditioning, Heating, cooling, and 9-9

9.5 Other Auxiliary Systems 9-12

10. EXPERIMENTAL FACILITIES/STEAY AND POOWER CONVERSION SYSTEM

10.1 Experimental Facilities 10-1

10.2 Turbine Generator 10-3

10.3 Main Steam Supply system 10-4

10.4 Other Features of steam and Power Conversion 10-7

11. RADIOACTIVE WASTE MANAGEMENT

11.1 Source Terms 11-1

11.2 Liquid Waste Management Systems 11-3

11.3 Gaseous Waste Management Systems 11-5

11.4 Solid Waste Management systems 11-7

11.5 Process and Effluent Radiological 11-10

Monitoring and sampling systems

12. RADIATION RROTECTION

12.1 Assuring That Occupational Exposures Are 12-1 As Low As Reasonably Achievable

12.2 Radiation Sources

$12-2$

12.3 Radiation Protection Design Features 12-4

12.4 Dose Assessment 12-8

13. CONDUCT OF OPERATIONS

13.1 Organizational structure 13-1

13.2 Training 13-4

13.3 Emergency Planning 13-5

13.4 Review and Audit 13-9

13.5 Plant Procedures 13-9

13.6 Industrial Security 13-11

14. INITIAL TEST PROGRAMB

14.1 Specific Information to be Included in 14-1 Preliminary Safety Analysis Reports

14.2 Initial Plant Test Program - Final Safety 14-1 Analysis Report 


\section{ACCIDENT ANALY8ES}

15.1 Increase in Heat Removal by the Secondary 15-1 System

15.2 Decrease in Heat Removal by the Secondary 15-3 System

15.3 Decrease in Forced Reactor Coolant Flow Rate

15.4 Reactivity and Power Distribution Anomalies

$15-7$

15.5 Increase in Reactor Coolant Inventory

15.6 Decrease in Reactor Coolant Inventory

15.7 Radioactive Release From a Subsystem or

$15-10$

$15-11$ Component

15.8 Anticipated Transients Without Scram

16. TECHNICAL BPECIFICATIONB

16.1 Technical Specifications (Preliminary 16-1 and Final)

17. QUALITY ASSURANCE

17.1 Quality Assurance During Design and 17-1 Construction

17.2 Quality Assurance (QA) During the Operations 17-5 Phase

18. HUMAN FACTORB ENGINEERING

18.1 Control room; Detailed Control Room 18-1 Design Review (DCRDR)

18.2 Safety Parameter Display System (SPDS) 18-3 
This document identifies nuclear safety criteria applied to NRC licensed reactors. The titles of the chapters and sections of USNRC Regulatory Guide 1.70, "Standard Format and content of Safety Analysis Reports for Nuclear Power Plants," Rev. 3, are used as the format for compiling the NRC criteria applied to the various areas of nuclear safety addressed in a safety analysis report for a nuclear reactor. In each section the criteria are compiled in four groups: (1) Code of Federal Regulations, (2) USNRC Regulatory Guides, SRP Branch Technical Positions and Appendices, (3) Codes and standards, and (4) supplemental Information. 
viii 
CHAPTER 1

\section{INTRODUCTION}

The Department of Energy (DOE) Order DOE 5480.6, "Safety of Department of Energy-Owned Nuclear Reactors," establishes reactor safety requirements to assure that reactors are sited, designed, constructed, modified, operated, maintained, and decommissioned in a manner that adequately protects health and safety and is in accordance with uniform standards, guides, and codes which are consistent with those applied to comparable licensed reactors.

This document identifies nuclear safety criteria applied to licensed reactors. The degree of application of these criteria to a DOE-owned reactor, consistent with their application to comparable licensed reactors, must be determined by the DOE and DOE contractor.

\subsection{PURPOSE}

This document is a compilation and source list of nuclear safety criteria that the Nuclear Regulatory Commission (NRC) applies to licensed reactors; it can be used by DOE and DOE contractors to identify NRC criteria to be evaluated for application to the DOE reactors under their cognizance. The criteria listed are those that are applied to the areas of nuclear safety addressed in the safety analysis report of a licensed reactor. They are derived from federal regulations, USNRC regulatory guides, standard Review Plan (SRP) branch technical positions and appendices, and industry codes and standards.

\subsection{SOURCES OF CRITERIA AND FORMAT}

To assure that this document includes all the areas of nuclear safety addressed in a. safety analysis report, USNRC Regulatory Guide: 1.70;" "Standard Format and Content of safety Analysis Reports for Nuclear Power Plants," Rev. 3 is used to establish the format of this document and the titles of each chapter and its subsections. The principal sources for the compiled nuclear safety criteria are Regulatory Guide 1.70 and NUREG-0800, USNRC "Standard Review Plan," June 1987. The compilation also includes criteria published since the last revision of these source documents. To eliminate excessive repetition, criteria are identified only in those subsections that address the thrust of the criteria. As an example, even though 10 CFR 50, Appendix B, "Quality Assurance," is applicable to all areas 
of nuclear safety, it is only listed in those sections that pertain to quality assurance. The criteria applicable to each subsection or area of safety are presented in a format represented by the following four groups.

\subsubsection{Code of Federal Regulations}

Generally, these criteria are provided in federal. regulations from specific sections of Title 10 of the code of Federal Regulations (10 CFR). In addition, other federal regulations are listed that were identified in separate NRC criteria sources for application to licensed reactors.

\subsubsection{O8NRC Regulatory Guides, BRP Branch Technical Positions and Appendices}

USNRC regulatory guides issued under Division 1, "Power Reactors," and Division 2, "Research and Test Reactors" are listed in this subsection. Regulatory guides from other divisions, such as Division 8, "Occupational Health" also are listed when pertinent to the areas of safety addressed in the safety analysis report. Branch technical positions and appendices to sections of the SRP are listed because they contain guidance and requirements that supplement or, in some instances, replace those provided in regulatory guides.

\subsubsection{Codes and standards}

The industry codes and standards listed in this subsection are those endorsed by the NRC in 10 CFR and regulatory guides, and those specified in the acceptance criteria and review procedures of the appropriate sections of Regulatory Guide 1.70 and the SRP. Depending on when sections of these documents were revised, their criteria often reference and endorse different issues of a code or standard. In addition, many of the industry standards specified in the NRC criteria have been revised or withdrawn and replaced by more recent standards.

Most of these obsolete standards are no longer issued by their sponsoring organization and, therefore, are not available for use by DOE or DOE contractors. Standards specified in the NRC criteria that were revised or replaced are identified and their replacement standards also listed. In most instances, the revised issues of obsolete standards that are endorsed by regulatory guides have incorporated the additional requirements specified in the regulatory guide.

\subsection{4 supplemental Information}

This subsection lists documents specified in the NRC criteria that do not fall within one of the three preceding 
groups of nuclear safety criteria. It includes appropriate sections from the SRP, NRC Information Notices and Bulletins, NUREGs, and other documents specified in the NRC criteria. Although these sources do not always specify requirements, they provide interpretations of the criteria, as well as methods specified by the NRC or considered acceptable to the NRC for implementing and satisfying the pertinent NRC criteria.

\subsection{DEVIATIONB FROM STANDARD FORYAT (RG 1.70)}

Recognizing the unique features and characteristics associated with many DOE reactors, Chapter 10 was expanded to include experimental facilities as well as the steam- and powerconversion systems that are specified in Regulatory Guide 1.70. As a result of the TMI-2 accident, human factors criteria were added to the SRP. Although Regulatory Guide 1.70 has not been revised to include such criteria, Chapter 18 of this document identifies human factors criteria specified in the SRP.

\subsection{BAFETY ANALYSIS REPORT CRITERIA}

This section compiles the criteria that address the need, preparation, and revision of a safety analysis report (SAR); such criteria are not included in the areas of nuclear safety addressed in a SAR. Criteria are also identified whose methods of implementation may affect the preparation of various sections of a SAR, particularly for new reactors.

\subsubsection{Code of Federal Regulations}

A. Commission Interim Policy statement, "Nuclear Power Plant Accident Considerations Under the National Environmental Policy Act of 1969," 45 FR 40101, June 13, 1980.

\section{B. Commission Policy statements.}

1. "systematic safety Evaluation of operating Nuclear Power Reactors," 49 FR 45112, November 15, 1984.

2. "Severe Reactor Accidents Regarding Future Designs and Existing Plants," 50 FR 32138, August 8, 1985.

3. "Safety Goals for the Operation of Nuclear Power Plants," 51 FR 30028, August 21, 1986.

4. "Maintenance of Nuclear Power Plants," 53 FR 9430 , March 23, 1988

5. "Maintenance of Nuclear Power Plants," 53 FR 50611, December 8, 1989. 
C. 10 CFR 50.33, "Contents of Applications, General
Information."

D. 10 CFR 50.34, "Contents of Applications, Technical Information."

E. $\quad 10$ CFR 50.36b, "Environmental Conditions."

F. 10 CFR 50.55, "Conditions of Construction Permits."

G. 10 CFR 50.59, "Changes, Tests, and Experiments."

Reports."

H. 10 CFR 50.71, "Maintenance of Records, Making

I. 10 CFR 50.75, "Reporting and Record Keeping for Decommissioning Planning."

1.4.2 NRC Regulatory Guides, BRP Branch Technical Positions and Appendices

A. Regulatory Guide 1.70, "Standard Format and Content of Safety Analysis Reports for Nuclear Power Plants."

1.4.3 Codes and standards

None.

1.4.4 supplemental Information

1987.

A. NUREG-0800, USNRC "Standard Review Plan," June 
CHAPTER 2

\section{SITE CHARACTERISTICS}

\subsection{GEOGRAPHY AND DEMOGRAPHY}

\subsubsection{Code of Federal Regulations} Information."

A. 10 CFR 50.34, "Contents of Applications, Technical

B. 10 CFR 100.3, "Definitions."

C. 10 CFR 100.10, "Factors to be considered when Evaluating sites."

D. 10 CFR 100.11, "Determination of Exclusion Area, Low Population Zone, and Population Center Distance."

2.1.2 UsNRC Regulatory Guides, SRP Branch Technical Positions and Appendices

A. Regulatory Guide 4.7, "General site suitability Criteria for Nuclear Power stations."

\subsubsection{Codes and standards}

A. None.

\subsubsection{Supplementary Information}

June 1987 .

A. NUREG-0800, USNRC "Standard Review Plan,"

1. SRP 2.1.1, "Site Location and Description."

Control."

2. SRP 2.1.2, "Exclusion Area Authority and

3. SRP 2.1.3, "Population Distribution."

B. NUREG-0308, "Safety Evaluation Report, Arkansas Nuclear One, Unit 2," USNRC, November 1977 and supplements.

C. NUREG-75/054, "Safety Evaluation Report, Pilgrim Nuclear Generating Station, Unit, 2," USNRC, June 1975 and supplements. 


\subsubsection{Code of Federal Regulations}

Information."

A. 10 CFR 50.34, "Contents of Applications; Technical

B. 10 CFR 100.10, "Factors to be considered When Evaluating sites."

\subsubsection{USNRC Regulatory Guides, BRP Branch Technical Positions} and Appendices

A. Regulatory Guide 1.78, "Assumptions for Evaluating the Habitability of a Nuclear Power Plant Control Room During a Postulated Hazardous Chemical Release."

B. Regulatory Guide 1.91, "Evaluations of Explosions Postulated to Occur on Transportation Routes Near Nuclear Power Plants."

C. Regulatory Guide 1.95, "Protection of Nuclear Power Plant Control Room Operators Against an Accidental Chlorine Release."

\subsection{3 codes and standards}

A. None.

\subsubsection{Supplementary Information}

June 1987.

A. NUREG-0800, USNRC "Standard Review Plan,"

1. SRP 2.2.1-2.2.2, "Identification of Potential Hazards in site Vicinity."

dents."

2. SRP 2.2.3, "Evaluation of Potential Acci-

B. NUREG-0014, "Safety Evaluation Report, Hartsville Nuclear Plants A1, A2, B1 and B2," USNRC, April 1976. Hazards."

C. IE circular 80-03, "Protection from Toxic Gas

D. TM5-1300, "Structures to Resist the Effects of Accidental Explosions," Department of the Army, June 1969. 
Criteria for regional climatology, local meteorology, onsite meteorological measurements program, and short-term and long-term diffusion estimates are identified in this section.

\subsubsection{Code of Federal Regulations}

A. 10 CFR 50.47, "Emergency Plans."

B. 10 CFR 50, Appendix A, "General Design Criteria for Nuclear Power Plants."

Natural Phenomena." GDC 2, "Design Bases for Protection Against

Bases."

2. GDC 4, "Environmental and Missile Design

3. GDC 19, "Control Room."

c. 10 CFR 50, Appendix E, "Emergency Planning and Preparedness for Production and Utilization Facilities."

D. 10 CFR 50, Appendix I, "Numerical Guides for Design objectives and Limiting Conditions for operation to Meet the Criterion 'As Low As Is Reasonably Achievable' for Radioactive Material in Light-Water-Cooled Nuclear Power Reactor Effluents."

Evaluating sites."

E. 10 CFR 100.10, "Factors to be considered when

F. 10 CFR 100.11, "Determination of Exclusion Area, Low Population Zone, and Population Center Distance."

2.3.2 USNRC Regulatory Guides, BRP Branch Technical Positions and Appendices

The method of calculating $x / Q$ values in Regulatory Guides $1.4,1.24,1.25$, and 1.77 is superseded by the method presented in Regulatory Guide 1.145, "Atmospheric Dispersion Models for Potential Accident Consequence Assessments at Nuclear Power Plants,"

A. Regulatory Guide 1.4, "Assumptions Used for Evaluating the Potential Consequences of a Loss-of-Coolant Accident for Pressurized Water Reactors." Programs."

B. Regulatory Guide 1.23," "Onsite Meteorological 
c. Regulatory Guide 1.24, "Assumptions Used for Evaluating the Potential Radiological Consequences of a Pressurized Water Reactor Radioactive Gas Storage Tank Failure."

D. Regulatory Guide 1.25," Assumptions Used for Evaluating the Potential Radiological Consequences of a Fuel Handling Accident in the Fuel Handling and storage Facility for Boiling and Pressurized water Reactors."

E. Regulatory Guide 1.27, "Ultimate Heat sink for Nuclear Power Plants."

F. Regulatory Guide 1.76, "Design Basis Tornado for Nuclear Power Plants."

G. Regulatory Guide 1.77, "Assumptions Used for Evaluating a Control Rod Ejection Accident for Pressurized Water Reactors."

H. Regulatory Guide 1.78, "Assumptions for Evaluating the Habitability of a Nuclear Power Plant Control Room During a Postulated Hazardous Chemical Release."

I. Regulatory Guide 1.95, "Protection of Nuclear Power Plant Control Room Operators Against an Accidental Chlorine Release."

J. Regulatory Guide 1.109, "Calculation of Annual Doses to Man From Routine Releases of Reactor Effluents for the Purpose of Evaluating Compliance with 10 CFR Part 50, Appendix I."

K. Regulatory Guide 1.111, "Methods for Estimating Atmospheric Transport and Dispersion of Gaseous Effluents in Routine Releases From Light-Water-Cooled Reactors."

L. Regulatory Guide 1.112, "Calculation of Releases of Radioactive Materials in Gaseous and Liquid Effluents From Light-Water-Cooled Power Reactors."

M. Regulatory Guide 1.145, "Atmospheric Dispersion Models for Potential Accident Consequence Assessments at Nuclear Power Plants."

N. Regulatory Guide 2.6, "Emergency Planning for Research and Test Reactors."

0. Regulatory Guide 4.2, "Preparation of Environmental Reports for Nuclear Power stations."

P. SRP 2.3.3, Appendix A, "Recommended Format for Hourly Meteorological Data to be Placed on Magnetic Tape."

$$
2-4
$$




\subsubsection{Codes and standards}

A. ANSI A58.1-1972, "Building Code Requirements for Minimum Design Loads in Buildings and other structures." (This standard was revised and issued as ANSI A58.1-1982, "Minimum Design Loads for Buildings and Other structures.")

Research Reactors."

B. ANSI/ANS 15.16-1982, "Emergency Planning for

\subsection{4 supplementary Information}

June 1987 .

A. NUREG-0800, USNRC "standard Review Plan,"

ments Programs."

$\begin{array}{lccc}\text { 1. } & \text { SRP } 2.3 .1, & \text { "Regional climatology." } \\ \text { 2. } & \text { SRP 2.3.2, "Local Meteorology." } \\ \text { 3." } & \text { SRP } 2.3 .3, & \text { "Onsite Meteorological Measure- } \\ \text { S." } & & \end{array}$

4. SRP 2.3.4, "Short-Term Diffusion Estimates for Accidental Atmospheric Releases."

5. SRP 2.3.5, "Long-Term Diffusion Estimates."

B. NUREG-0849, "Standard Review Plan for the Review and Evaluation of Emergency Plans for Research and Test Reactors," USNRC, October 1983.

C. NUREG-0396 (EPA 520/1-78-016), "Planning Basis for the Development of state and Local Government Radiological Emergency Response Plans in support of Light-Water Nuclear Power Plants," USNRC, December 1978 .

D. NUREG-0324, "XOQDOQ Program for the Meteorological Evaluation of Routine Effluent Releases at Nuclear Power stations," (DRAFT), September 1977.

E. WASH-1300, "Technical Basis for Interim Regional Tornado Criteria," USAEC, May 1974.

F. NUREG/CR-226. "Technical Basis for Regulatory Guide 1.145, Atmospheric Dispersion Models for Potential Accident Consequence Assessment at Nuclear Power Plants,' W.G. Snell and R.W. Jubach, NUS Corp., October 1981.

G. U.S. Department of Commerce, "Local Climatological Data - Annual Summary with Comparative Data," Environmental Data Service, NOAA, published annually.

$$
2-5
$$


H. U.S. Department of Commerce, "state climatological Summary," Environmental Data Service, NOAA, published annually by state.

I. U.S. Department of Commerce, "Storm Data," Environmental Data service, NOAA, published monthly.

J. EPA-600/4-76-030a, "Atmospheric Dispersion Parameters in Gaussian Plume Modeling," A.H. Weber, USEPA, July 1976.

K. AP-101, "Mixing Heights, wind speeds, and Potential for Urban Air Pollution Throughout the Contiguous United States," G.C. Holzworth, Office of Air Programs, USEPA, January 1972 .

L. Publication No. 99-AP-34, "Climatology of stagnating Anticyclones East of the Rocky Mountains, 1936-1970," J. Korshover, Public Health Service, October 1971.

M. "New Distribution of Extreme winds in the United states," Journal of the structural Division, Proceedings of the American Society of Civil Engineers, H.C.S. Thom, pp. 1787-1801, July 1968 .

N. U.S. Department of Commerce, "Climatic Atlas of the United States," Environmental Data Service," NOAA, June 1968.

o. TID-24190, "Meteorology and Atomic Energy," D.H. slade (ed.), Division of Technical Information, USAEC, 1968.

P. IDO-12048, "Climatography of the National Reactor Testing station," G.R. Yanskey, E.H. Markee, and A.P. Richter, Idaho Operations office, USAEC, 1966.

Q. "Handbook of statistical Methods in Meteorology," C.E.P. Brooks and N. Caruthers, M.O. 538, Her Majesty's Stationary office, London, 1953.

\subsection{HYDROLOGIC ENGINEERING}

Criteria for hydrologic design considerations; floods; probable maximum flood, surge and seiche flooding, and tsunami flooding; seismically induced potential dam failures; ice effects; flood protection requirements; low water considerations; dispersion, dilution, and travel times of accidental releases of liquid effluents in surface water; and groundwater considerations are identified in this section. 


\subsubsection{Code of Federal Regulations}

A. 10 CFR 20, Appendix B, "Concentrations in Air and Water Above Natural Background."

B. 10 CFR 50.55, "Conditions of Construction Permits."

C. 10 CFR 50.55a, "Codes and Standards."

D. 10 CFR 50, Appendix A, "General Design Criteria for Nuclear Power Plants."

Natural Phenomena."

1. GDC 2, "Design Bases for Protection Against

Bases."

2. GDC 4, "Environmental and Missile Design

3. GDC 5, "Sharing of structures, systems, and Components."

4. GDC 44, "cooling water."

E. 10 CFR 100.10, "Factors to be considered when Evaluating sites."

F. 10 CFR 100, Appendix A, "Seismic and Geologic siting Criteria for Nuclear Power Plants."

2.4.2 USNRC Regulatory Guides, SRP Branch Technical Position and Appendices

A. Regulatory Guide 1.27, "Ultimate Heat Sink for Nuclear Power Plants."

cation."

B. Regulatory -Guide 1.29, "Seismic Design Classifi-

C. Regulatory Guide 1.59, "Design Basis Floods for Nuclear Power Plants."

D. Regulatory Guide 1.102, "Flood Protection for Nuclear Power Plants."

E. Regulatory Guide 1.113, "Estimating Aquatic Dispersion of Effluents from Accidental and Routine Reactor Releases for the Purpose of Implementing Appendix I."

F. Regulatory Guide 1.125, "Physical Models for Design and operation of Hydraulic structures and systems for Nuclear Power Plants." 
G. Regulatory Guide 4.4, "Reporting Procedure for Mathematical Models Selected to Predict Heated Effluent Dispersion in Natural Water Bodies."

site Visits."

SRP 2.4.1, Appendix A, "Hydrologic Engineering

I. SRP 2.4.12, Branch Technical Position HGEB-1, "Safety-Related Permanent Dewatering Systems."

\subsubsection{Codes and standards}

A. ANSI N170-1976, "Standards for Determining Design Basis Flooding at Power Reactor sites." (This standard was revised and issued as ANSI/ANS 2.8-1981, "Determining Design Basis Flooding at Power Reactor sites.")

\subsubsection{Bupplementary Information}

June 1987.

A. NUREG-0800, USNRC "Standard Review Plan,"

1. SRP 2.4.1, "Hydrologic Description."

2. SRP 2.4.2, "Floods."

3. SRP 2.4.3, "Probable Maximum Flood (PMF) on
Streams and Rivers."

4. SRP 2.4.4, "Potential Dam Failures."

5. SRP 2.4.5, "Probable Maximum surge and Seiche Flooding."

ing."

6. SRP 2.4.6, "Probable Maximum Tsunami Flood-

voirs."

ments."

7. SRP 2.4.7, "Ice Effects."
8. SRP 2.4.8, "Cooling Water Canals and Reser-

9. SRP 2.4.9; "Channel Diversions."

10. SRP 2.4.10, "Flooding Protection Require-

11. SRP 2.4.11, "Cooling Water Supply."

12. SRP 2.4.12, "Ground Water." 
13. SRP 2.4.13, "Accidental Releases of Liquid Effluents in Ground and Surface Waters."

14 SRP 2.4.14, "Technical specifications and
Emergency Operation Requirements."

B. NUREG-0693, "Analysis of Ultimate Heat sink cooling Ponds," USNRC, 1980.

C. NUREG-0044, "An Assessment of Techniques for Hydrothermal Prediction," USNRC, 1976.

D. Because of the geographic diversity of plant sites and the large number of hydrologic references provided in the acceptance criteria and review procedures, no specific tabulation is given here of maps and charts by the USGS, NOAA, Army Map Service (AMS), and Federal Aviation Administration (FAA); watersupply papers of the USGS; River Basin Reports of the Corps of Engineers; and other publications of state, federal and other regulatory bodies, describing hydrologic characteristics and water utilization in the plant vicinity and region. Design Memoranda, civil Works Investigations, research and development reports of the corps of Engineers, and reports of other federal and state agencies relevant to flood estimates at a specific site should be used on an "as-available" basis. Hydrologic information and data are published in the following:

of the Army.

1. Reports of the Corps of Engineers, Department

2. Technical Papers of the U.S. Weather Bureau (currently titled, U.S. Weather Service, NOAA).

3. Hydrometeorological Reports of the U.S. Weather Bureau (currently titled, U.S. Weather service, NOAA) Hydrometeorological Branch.

4. Unpublished Hydrometeorological Reports of the U.S. Weather Bureau (currently titled, U.S. Weather Service, NOAA) . Geological survey.

E. "Surface Water Supply of the United states," U.S. F. "Tide Tables," National oceanic and Atmospheric Administration

G. HEC-5, "Reservoir System Operation for Flood Control," U.S. Army Corps of Engineers Hydrologic Engineering Center, Davis, California, May 1973. 
H. "A Method for Analyzing Effects of Dam Failures in Design studies," W.A. Thomas, Corps of Engineers Hydrologic Engineering Center, Davis California (for presentation at the ASCE Hydraulics Division Specialty Conference, Cornell University, August 1972).

I. BNWL-1718, "One-Dimensional Model of the Movement of Trace Radioactive Solutes Through Soil Columns: The PERCOL Model," R.C. Routson and R.J. Serne, Battelle Pacific Northwest Laboratories, Richland, Washington, 1972.

J. HEC-1, "Flood Hydrograph Package," U.S. Army Corps of Engineers Hydrologic Engineering Center, Davis, California, October 1970 .

K. 723-62-L2450, "Gradually Varied Unsteady Flow Profiles," U.S. Army Corps of Engineers Hydrologic Engineering Center, Davis, California, March 1969.

L. Misc. Paper No. 2-374, Report 2, "Floods Resulting From Suddenly Breached Dams, Conditions of High Resistance," U.S. Army Corps of Engineers, 1961.

M. Military Hydrology Bulletin No. 9, "Flow Through a Breached Dam," U.S. Army Corps of Engineers, 1957.

\subsection{GEOLOGY, BEIBMOLOGY, AND GEOTECHNICAL ENGINEERING}

Criteria for geologic and seismic information; vibratory ground motion; surface faulting; stability of subsurface materials and foundations; stability of slopes, and for embankments and dams are identified in this section.

\subsubsection{Code of Federal Regulations}

A. 10 CFR 50, Appendix A, "General Design Criteria for Nuclear Power Plants."

1. GDC: 1, "Quality standards and Records."

2. GDC 2, "Design Bases for Protection Against Natural Phenomena."

$$
\text { 3. GDC 44, "Cooling Water." }
$$

B. 10 CFR 100.10, "Factors to be Considered when Evaluating sites."

c. 10 CFR 100, Appendix A, "Seismic and Geologic siting criteria for Nuclear Power Plants."

$$
2-10
$$


2.5.2 UskRC Regulatory Guides, BRP Branch Technical Positions and Appendices

A. Regulatory Guide 1.27, "Ultimate Heat sink for Nuclear Power Plants."

B. Regulatory Guide 1.28, "Quality Assurance Program Requirements (Design and Construction)."

C. Regulatory Guide 1.60, "Design Response Spectra for Seismic Design of Nuclear Power Plants."

D. Regulatory Guide 1.132, "Site Investigations for Foundations of Nuclear Power Plants."

E. Regulatory Guide 1.138, "Laboratory Investigations of Soils for Engineering Analysis and Design of Nuclear Power Plants."

F. Regulatory Guide. 4.7, "General Site suitability Criteria for Nuclear Power stations."

2.5.3 codes and standards

None.

2.5.4 Bupplementary Information

1987.

A NUREG-0800, USNRC "Standard Review Plan," June Information."

1. SRP 2.5.1; "Basic Geologic and seismic

2. SRP 2.5.2, "Vibratory Ground Motion."

3. SRP 2.5.3, "Surface Faulting."

4. SRP 2.5.4, "Stability of subsurface Materials and Foundations."

5. SRP 2.5.5, "Stability of slopes.".

B. NUREG-0625, "Report of siting Policy Task Force," USNRC, August 1979 . 
C. NUREG-0402, "Analysis of a Worldwide strong Motion Data sample to Develop an Improved Correlation Between Peak Acceleration, Seismic Intensity and Other Physical Parameters," USNRC, September 1977.

D. NUREG-0029, Vol. 2, June 1976 and NUREG/CR-0985, 1980, "Geotechnical and strong Motion Earthquake Data from U.S. Accelerograph stations," prepared by Shannon and wilson; Inc. and Agbabian Associates.

E. NUREG/CR-1577, "A Seismic Zone Map for siting Nuclear Electric Generating Facilities in the Eastern United states," N. Barstow, K. Brill, O. Nuttli, and P. Pomeroy, Roundout Associates, Inc., 1980.

F. IE Circular 81-08, "Foundation Materials."

G. "Earthquake History of the United States (1971-76 Supplement)," Publication 41-1, National Oceanic and Atmospheric Administration, U.S. Department of Commerce; Geological Survey, U.S. Department of Interior, 1979.

H. "Variations of strong Earthquake Ground Shaking in the Los Angeles Area," M.D. Trifunac and F.E. Udwadia, Bulletin Seismological Society of America, Vol. 64, 1974.

I. "Duration of Strong Ground Motion," B.A. Bolt, Proceedings of the Fifth World Conference on Earthquake Engineering, 1973.

J. Report No. EERC 73-2, "Analysis of the slides in the San Fernando Dams During the Earthquake of February 9, 1971," H.B. Seed, K.L. Lee, I.M. Idriss, and F. Makdisi, Earthquake Engineering Research Center, University of California, Berkeley, 1973 .

K. "Love and Rayleigh Waves in Nonhorizontally Layered Media," L.A. Drake, Bulletin Seismological Society of America, Vol. 62, 1972 .

L. Report No. EERC 72-12," "SHAKE-A Computer Program for Earthquake Response Analysis of Horizontally Layered Sites," P.B. Schnabel, J. Lysmer, and H.B. Seed, Earthquake Engineering Research Center, University of California, Berkeley, 1972.

M. Report EERC 72-2, "Acceleration in Rock for Earthquakes in the Western United States," P.B. Schnabel and H.B. Seed, Earthquake Engineering Center, University of California, Berkeley, 1972 .

N. EM 1110-2-1907, "Soil Sampling," U.S. Army Corps of Engineers, March 1972 . 
O. EM 1110-2-1908, "Instrumentation of Earth and Rock Fill Dams," U.S. Army Corps of Engineers, August 1971.

P. NAVFAC DM-7, "Soil Mechanics, Foundations, and Earth Structures," Department of the Navy, March 1971.

Q. EM 1110-2-1906, "Laboratory Soil Testing," U.S. Army Corps of Engineers, November 1970.

R. EM 1110-2-1902, "Engineering and Design stability of Earth and Rock-Fill Dams," U.S. Army Corps of Engineers, 1970.

S. "Effects of Earthquakes on Dams and Embankments," N.M. Newmark, Geotechnique, 15: 140-141; 156,. The Institution of Civil Engineers, London, 1969.

T. "Earth Manual," First Edition, Bureau of Reclamation, U.S. Dept. of Interior, 1968.

U. TM 5-818-1 (formerly EM 1110-345-147), "Procedures for Foundation Design of Buildings and Other structures (Except Hydraulic Structures)," U.S. Army Corps of Engineers, 1965.

V. "Earthquâḱ "Energy and Ground Breakage," D. Tocher, Bulletin Seismological sóciety

$$
\text { iftion }
$$

W. "Two Propos'ed Meásurés, of Seismicity," P. st. Amand, Bulletin Seismologicallsociety of America, vol. 46, pp. 41-45, 1956 .

X. "Subsurface Exploration and Sampling of soils for Civil Engineering Purposes," M. Juul Hvorslev, Waterways Experiment Station, U.S. Army Corps of Engineers, November 1949 .

Y. "Historical Earthquake Data File," National Geophysical and Solar-Terrestrial Data Center, National Oceanic and Atmospheric Administration.

Z. GEODEX INTERNATIONAL, SOil Mechanics Information Service, Sonoma, California. 


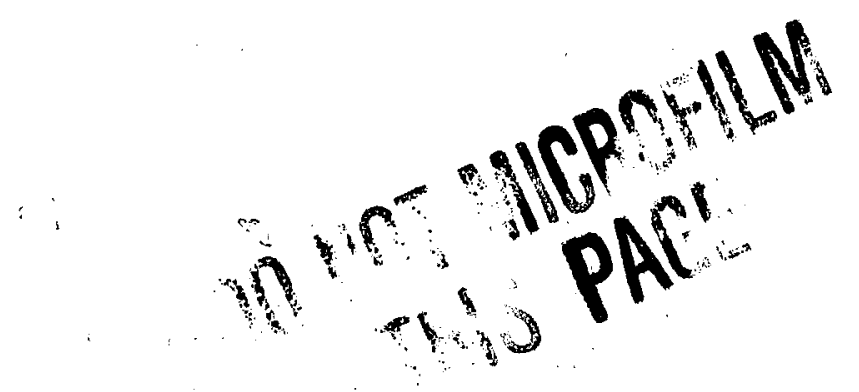

分

$2-14$ 


\section{CHAPTER 3}

DEBIGN OF STRUCTURES, COMPONENTS, EQUIPMENT AND SYSTEMS

This chapter identifies the principal architectural and engineering criteria for the design of structures, components, equipment, and systems important to safety.

\subsection{CONFORMANCE WITH NRC GENERAL DEBIGN CRITERIA}

This section in a SAR contains a brief discussion of the extent to which the facility structures, systems, and components important to safety meet the general design criteria.

3.1.1 Code of Federal Regulations

A. 10 CFR 50, Appendix A, "General Design Criteria for Nuclear Power Plants," (all GDCs are to be addressed).

3.1.2 USNRC Regulatory Guides, sRP Branch Technical Positions and Appendices

None.

3.1.3 Codes and standards

None.

3.1.4 Supplemental Information

None.

3.2 CLASSIFICATION OF STRUCTURES, COMPONENTS, AND SYSTEMS

This section identifies criteria for seismic classification and system quality group classifications.

3.2.1 Code of Federal Regulations

A. 10 CFR 50.55a, "Codes and standards."

B. 10 CFR 50, Appendix A, "General Design Criteria for Nuclear Power Plants."

1. GDC 1, "Quality Standards and Records."

2. GDC 2, "Design Bases for Protection Against

Natural Phenomena." 
C. 10 CFR 100, Appendix A, "Seismic and Geologic siting Criteria for Nuclear Power Plants."

3.2.2 UsNRC Regulatory Guides, SRP Branch Technical Positions
and Appendices

A. Regulatory Guide 1.26, "Quality Group Classifications and standards for water-, steam-, and Radioactive-WasteContaining Components of Nuclear Power Plants."

cation."

B. Regulatory Guide 1.29," "Seismic Design Classifi-

\subsubsection{Codes and standards}

A. ANSI B16.34-1977, "Valves-Flanged and Butt-Welding End Steel, Nickel Alloy, and other Special Alloys." (This standard was revised and issued as ANSI B16.34-1988, "Valves-Flanged, Buttwelded and Threaded End.")

B. ANSI B96.1-1980, "specification for welded Aluminum-Alloy Storage Tanks." (This standard was revised and issued as ANSI/ASME B96.1-1986, "specification for Welded Aluminum-Alloy Storage Tanks.")

C. ANSI/ASME B31.1, "PoWer Piping."

D. ANSI/API 620-1978, "Recommended Rules for Design and Construction of Large, Welded, Low-Pressure Storage Tanks." (This standard was revised and issued as ANSI/API 620-1986, "Recommended Rules for Design and Construction of Large, Welded, Low-Pressure storage Tanks.")

storage."

E. ANSI/API 650-1980," "Welded steel Tanks for oil

F. ANSI/AWWA D100-1979, "Welded Steel Elevated Tanks, Standpipes, and Reservoirs for Water storage." (This standard was revised and issued as ANSI/AWWA D100-1984," "AWWA Standard for Welded Steel Tanks for Water storage.")

G. ASME Boiler and Pressure Vessel Code.

1. Section III, "Rules for construction of Nuclear Power Plant Components," Division 1 .

2. Section VIII, "Rules for Construction of Pressure Vessels," Division 1.

3. Section XI, "Rules for Inservice Inspection of Nuclear Power Plant Component's." 
3.2.4 Bupplemental Information

1987 .

A. NUREG-0800, USNRC "Standard Review Plan," June

cation."

1. SRP 3.2.1, "Seismic classification."

2. SRP 3.2.2, "System Quality Group classifi-

3.3 WIND AND TORMADO LOADINGS

3.3.1 Code of Federal Regulations

A. 10 CFR 50, Appendix A, "General Design Criteria for Nuclear Power Plants."

Natural Phenomena."

1. GDC 2, "Design Bases for Protection Against

3.3.2 U8NRC Regulatory Guides, 8RP Branch Technical Positions and Appendices

A. Regulatory Guide 1.76, "Design Basis Tornado for Nuclear Power Plants."

cation."

B. Regulatory Guide 1.117, "Tornado Design Classifi-

3.3.3 Codes and standards

A. ANSI A58.1-1972, "Building Code Requirements for Minimum Design Loads in Buildings and other structures." (This standard was revised and issued as ANSI A58.1-1982, "Minimum Design Loads for Buildings and other structures.")

3.3.4 Supplemental Information

1987.

A. NUREG-0800, USNRC "Standard Review Plan," June

1. SRP" 3.3:1, "Wind Loadings."

2. SRP 3.3.2, "Tornado Loadings."

B. ASCE Paper No. 3269 , "Wind Forces on Structures," Transactions of the American society of Civil Engineers, Vol. 126, Part 11, 1961. 
C. "Tornado-Resistant Design of Nuclear Power Plant structures," J.R. McDonald, K.C. Mehta, and J.E. Miner, Nuclear safety, Vol. 15, No. 4, July-August 1974.

\subsection{WATER LEVEL (FLOOD) DEBIGN}

\subsubsection{Code of Federal Regulations}

A. 10 CFR 50, Appendix A, "General Design Criteria for Nuclear Power Plants."

Natural Phenomena."

1. GDC 2, "Design Bases for Protection Against

B. 10 CFR 100, Appendix A, "Seismic and Geologic siting Criteria for Nuclear Power Plants."

3.4.2 U8NRC Regulatory Guides, SRP Branch Technical Positions and Appendices

A. Regulatory Guide 1.59, "Design Basis Floods for Nuclear Power Plants."

B. Regulatory Guide 1.102, "Flood Protection for Nuclear Power Plants."

c. Regulatory Guide 1.125, "Physical Models for Design and operation of Hydraulic structures and systems for Nuclear Power Plants."

D. Regulatory Guide 1.135, "Normal Water Level and Discharge at Nuclear Power Plants."

\subsubsection{Codes and standards.}

A. ANSI N170-1976, "Standards for Determining Design Basis Flooding at Power Reactor sites." (This standard was revised and issued as ANSI/ANS 2.8-1981, "Determining Design Basis Flooding at Power Reactor sites.")

3.4.4 Bupplemental Information

A. NUREG-0800, USNRC "Standard Review Plan," June 1987

1. SRP 3.4.1, "Flood Protection."

2. SRP 3.4.2, "Analysis Procedures."

B. "Shore Protection Manual," 3rd Edition, U.S. Army Coastal Engineering Research Center, 1977. 


\section{5}

\section{MI8SILE PROTECTION}

This section identifies criteria for protection against missiles generated because of internal events, events near the site, natural phenomena, and aircraft hazards.

\subsubsection{Code of Federal Regulations}

A. 10 CFR 50, Appendix A, "General Design Criteria for Nuclear Power Plants."

Natural Phenomena."

1. GDC 2, "Design Basis for Protection Against

2. GDC 3, "Fire Protection."

Bases."

3. GDC 4, "Environmental and Missile Design

B. 10 CFR 100.10, "Factors to be Considered when Evaluating sites."

C. 10 CFR 100.11, "Determination of Exclusion Area, Low Population Zone, and Population Center Distance."

3.5.2 USNRC Regulatory Guides, BRP Branch Technical Positions and Appendices

A. Regulatory Guide 1.13, "Spent Fuel storage Facility Design Basis."

B. Regulatory Guide 1.27, "Ultimate Heat sink for Nuclear Power Plants."

C. Regulatory Guide 1.76, "Design Basis Tornado for Nuclear Power Plants."

D. Regulatory Guide 1.91, "Evaluations of Explosions Postulated to Occur on Transportation Routes Near Nuclear Power Plants."

E. Regulatory Guide 1.115, "Protection Against Low Trajectory Turbine Missiles."

G. SRP 3.5.3, Appendix A," "Permissible Ductility

F. Regulatory Guide 1.117 , "Tornado Design ClassifiRatio for Overall Damage Prediction." 


\subsubsection{Codes and standards}

None.

\subsection{4 supplemental Information}

1987.

A. NUREG-0800, USNRC "Standard Review Plan," June

tion."

$$
\text { 1. SRP 3.5.1, "Missile Selection and Descrip- }
$$

2. SRP 3.5.2, "Structures, systems, and components to be Protected from Externally Generated Missiles."

3. SRP 3.5.3, "Barrier Design Procedures."

B. NUREG-0533, "Aircraft Impact Risk Assessment Data Base for Assessment of Fixed Wing Air Carrier Impact Risk in the Vicinity of Airports," USNRC, June 1979.

C. WASH-1300, "Technical Basis for Interim Regional Tornado Criteria," USAEC, May 1974.

D. TM-5-855-1, "Fundamentals of Protective Design," Department of the Army, July 1965.

E. ORNL-NSIC-5, "U.S. Reactor Containment Technology," Vol. 1, Chapter 6, W.B. Cottrell and A.W. Savolainen, Oak Ridge National Laboratory.

F. "Ballistic Performance Dynamics," R.F. Recht and T.W. Ipson, Journal of Applied Mechanics, Transactions of the ASME, Vol. 30, Series E, No. 3, September 1963.

G. "Impact of Fragments Striking structural Elements," R.A. Williamson and R.R. Alvy, Holmes and Narver, Inc., revised November 1973 .

H. "A Review of Procedures for the Analysis and Design of Concrete structures to Resist Missile Impact Effects," R.P. Kennedy, Holmes and Narver, Inc., September 1975.

3.6 PROTECTION AGAINST DYNAMIC EFFECTS ASSOCIATED WITH THE POSTULATED RUPTURE OF PIPING

3.6.1 Code of Federal Regulations

A. 10 CFR 50, Appendix A, "General Design Criteria for Nuclear Power Plants." 
Bases."

1. GDC 4, "Environmental and Missile Design

3.6.2 USNRC Regulatory Guides, 8RP Branch Technical Positions and Appendices

A. Regulatory Guide 1.11, "Instrument Lines Penetrating Primary Reactor Containment."

cation."

B. Regulatory Guide 1.29, "Seismic Design Classifi-

C. SRP 3.6.1, Branch Technical Position ASB 3-1, "Protection Against Postulated Piping Failures in Fluid systems outside containment." (This BTP was revised by 53 FR 1968, $01 / 25 / 88$.)

D. SRP 3.6.2, Branch Technical Position MEB 3-1, "Postulated Rupture Locations in Fluid system Piping Inside and outside containment."

\subsubsection{Codes and standards}

A. ASME Boiler and Pressure Vessel Code.

1. Section III, "Rules for construction of Nuclear Power Plant Components," Division 1.

2. Section XI, "Rules for Inservice Inspection of Nuclear Power Plant Components."

\subsection{4 supplemental Information}

1987 .

A. NUREG-0800, USNRC "Standard Review Plan," June

1. SRP 3.6.1, "Plant Design for Protection Against Postulated Piping Failures in Fluid systems Outside Containment."

2. SRP 3.6.2, "Determination of Rupture Locations and Dynamic Effects Associated with the Postulated Rupture of Piping."

B. NUREG-0609, "Asymmetric Blowdown Loads on PWR Primary Systems," USNRC, January 1981.

C. "Prediction of Blowdown and Jet Thrust Forces," F.J. Moody, ASME Paper 69 HJ-31, August 6, 1969. 
This section identifies criteria for seismic input, analysis of seismic Category I structures, systems, and components, and seismic instrumentation.

3.7.1 Code of Federal Regulations

A. 10 CFR 50.55a, "Codes and Standards."

B. 10 CFR 50, Appendix A, General Design Criteria for Nuclear Power Plants."

Natural Phenomena."

1. GDC 2, "Design Bases for Protection Against

C. 10 CFR 100, Appendix A, "Seismic and Geologic siting Criteria for Nuclear Power Plants."

\subsubsection{USNRC Regulatory Guides, SRP Branch Technical Positions} and Appendices

Earthquakes."

A. Regulatory Guide 1.12, "Instrumentation for

B. Regulatory Guide 1.60, "Design Response Spectra for Seismic Design of Nuclear Power Plants."

C. Regulatory Guide 1.61, "Damping Values for Seismic Design of Nuclear Power Plants."

D. Regulatory Guide 1.92, "Combining Modal Responses and Spatial Components in Seismic Response Analysis."

E. Regulatory Guide 1.122, "Development of Floor Design Response Spectra for Seismic Design of Floor-supported Equipment or Components."

\subsubsection{Codes and standards}

A. ANSI N18.5-1974, "Earthquake Instrumentation Criteria for Nuclear Power Plants." (This standard was revised and issued as ANS/ANSI 2.2-1988, "Earthquake Instrumentation Criteria for Nuclear Power Plants.")

3.7.4 Supplemental Information

A. NUREG-0800 USNRC "Standard Review Plan," June 1987. 1. SRP 3.7.1, "Seismic Design Parameters." 


$$
\begin{array}{lll}
\text { 2. } & \text { SRP } 3.7 .2, & \text { "Seismic System Analysis." } \\
\text { 3. } & \text { SRP } 3.7 .3, & \text { "Seismic Subsystem Analysis." } \\
\text { 4. } & \text { SRP 3.7.4, "Seismic Instrumentation." }
\end{array}
$$

\subsection{DEBIGN OF CATEGORY I BTRUCTUREB}

This section identifies criteria for concrete containment, steel containment, internal containment structures, foundations, and other Seismic Category I structures.

3.8.1 Code of Federal Regulations

A. 10 CFR 50.55a, "Codes and Standards."

B. 10 CFR 50, Appendix A, "General Design Criteria for Nuclear Power Plants."

1. GDC 1, "Quality Standards and Records."

2. GDC 2, "Design Bases for Protection Against Natural Phenomena."

Bases."

3. GDC 4, "Environmental and Missile Design

4. GDC 5, "Sharing of structures."

5. GDC 16, "Containment Design."

6. GDC 50,: "Containment Design Basis."

3.8.2 UsNRC Regulatory Guides, 8RP Branch Technical positions and Appendices

Regulatory Guides $1.10,1.15,1.18,1.19,1.55$, and 1.103 were withdrawn and are superseded by Regulatory Guide 1.136, "Materials, Construction, and Testing of Concrete Containments."

A. Regulatory Guide 1.10, "Mechanical (Cadweld) Splices in Reinforcing Bars of Category I Concrete structures."

B. Regulatory Guide 1.15, "Testing of Reinforcing Bars for Category I Concrete Structures."

C. Regulatory Guide 1.18, "Structural Acceptance Test for Concrete Primary Reactor Containments." 
D. Regulatory Guide 1.19, "Nondestructive Examination of Primary Containment Liner Welds."

E. Regulatory Guide 1.35, "Inservice Inspection of Ungrouted Tendons in Prestressed Concrete containment structures."

F. Regulatory Guide 1.55, "Concrete Placement in Category I structures."

G. Regulatory Guide 1.57, "Design Limits and Loading Combinations for Metal Primary Reactor Containment system Components."

H. Regulatory Guide 1.69, "Concrete Radiation Shields for Nuclear Power Plants."

I. Regulatory Guide 1.90," "Inservice Inspection of Prestressed concrete containment structures with Grouted Tendons."

J. Regulatory Guide 1.91, "Evaluations of Explosions Postulated to Occur on Transportation Routes Near Nuclear Power Plants."

K. Regulatory Guide 1.94, "Quality Assurance Requirements for Installation, Inspection, and Testing of Structural Concrete and structural steel During the Construction Phase of Nuclear Power Plants."

L. Regulatory Guide 1.103," "Post-Tensioned Prestressing systems for Concrete Reactor Vessels and Containments."

M. Regulatory Guide 1.107, "Qualifications for cement Grouting for Prestressing Tendons in Containment structures."

N. Regulatory Guide 1.115, "Protection Against Low Trajectory Turbine Missiles."

o. Regulatory Guide 1.136, "Materials, Construction, and Testing of concrete containments."

P. Regulatory Guide 1.142, "Safety-Related Concrete structures for Nuclear Power Plants (Other Than Reactor Vessels and Containments)."

Q. Regulatory Guide 1.143, "Design Guidance for Radioactive Waste Management systems, Structures, and components Installed in Light-Water-Cooled Nuclear Power Plants." 
R. SRP 3.8.4, Appendix A, "Interim Criteria for Safety-Related Masonry Wall Evaluation."

Audits."

S. SRP 3.8.4, Appendix B, "structural Design

T. SRP 3.8.4, Appendix C, "Design Report."

U. SRP 3.8.4, Appendix D, "Technical Position on Spent Fuel Pool Racks."

\subsubsection{Codes and standards}

A. ACI 318-1971, "Building Code Requirements for Reinforced Concrete." (This standard was revised and issued as ANSI/ACI 318-1983, "Building Code Requirements for Reinforced Concrete.")

B. AISC, "Manual of steel Construction," Part 5, "Specification for Design, Fabrication, and Erection of structural steel for Buildings."

C. ANSI N45.2.5-1978, "Supplementary Quality Assurance Requirements for Installation, Inspection, and Testing of Structural concrete and structural steel During the Construction Phase of Nuclear Power Plants." (This standard was withdrawn on $03 / 21 / 84$ and incorporated into ANSI/ASME NQA-2, "Quality Assurance Requirements for Nuclear Power Plants.")

D. ANSI N101.6-1972, "Concrete Radiation Shields." (This standard was withdrawn in 1981; it was replaced by ANSI/ACI 349-1980, "Code Requirements for Nuclear Safety-Related Concrete Structures" and ANSI/ANS 6.4-1985, "Guidelines on the Nuclear Analysis and Design of Concrete Radiation Shielding for Nuclear Power Plants.")

E. ANSI/ACI 309-1972(R1978), "Recommended Practice for Consolidation of Concrete."

F. ANSI/ACI 349-1980, "Code Requirements for Nuclear Safety-Related Concrete structures;" and ACI 349R-80," "Commentary."

G. ANSI/ANS 6.4-1985; "Guidelines on the Nuclear AnalYsis and Design of Concrete Radiation Shielding for Nuclear Power Plants." 
H. ANSI/API 620-1978, "Recommended Rules for Design and Construction of Large, Welded, Low-Pressure Storage Tanks." (This standard was revised and issued as ANSI/API 620-1986, "Recommended Rules for Design and Construction of Large, Welded, Low-Pressure storage Tanks.")

I. ANSI/API 650-1980, "Welded steel Tanks for Oil
storage."

J. ANSI/ASME B31.1, "Power Piping."

K. ANSI/AWWA D100-1979, "Welded Steel Elevated Tanks, standpipes, and Reservoirs for Water storage." (This standard was revised and issued as ANSI/AWWA D100-1984, "AWWA Standard for Welded steel Tanks for Water storage.")

L. ASME Boiler and Pressure Vessel Code.

1. Section III, "Rules for construction of Nuclear Power Plant Components," Division 1 and Division 2 . sure Vessels," Division 1.

2. Section VIII, "Rules for Construction of Pres3.8.4 Supplemental Information

1987 .

A. NUREG-0800, USNRC "Standard Review Plan," June

1. SRP 3.8.1, "Concrete Containment."

2. SRP 3.8.2, "Steel Containment."

3. SRP 3.8.3, "Concrete and steel Internal structures of steel or Concrete containments."

tures."

4. SRP 3.8.4, "Other Seismic Category I Struc-

5. SRP 3.8.5, "Foundations."

B. IE Bulletin 80-11, "Masonry Wall Design."

C. IE Information Notice 79-28, "Overloading of structural Elements Due to Pipe Support Loads."

D. IE Information Notice 87-67, "Lessons Learned from Regional Inspections of Licensee Actions in Response to IE Bulletin 80-11." 
This section identifies criteria for ASME code and noncode items, control rod drive systems, and reactor pressure vessel internals.

3.9.1 Code of Federal Regulations

A. 10 CFR 50.55a, "Codes and standards."

B. 10 CFR 50, Appendix A, "General Design Criteria for Nuclear Power Plants."

1. GDC 1, "Quality standards and Records."

2. GDC 2, "Design Bases for Protection Against Natural Phenomena."

Bases."

3. GDC 4, "Environmental and Missile Design

4. GDC 10, "Reactor Design."

5. GDC 14, "Reactor Coolant Pressure Boundary."

6. GDC 15, "Reactor Coolant System Design."

and Capability." GDC 26, "Reactivity Control system Redundancy Capability."

8. GDC 27, "Combined Reactivity Control systems

9. GDC 29, "Protection Against Anticipated Operational Occurrences."

system."

10. GDC 37, "Testing of Emergency Core cooling system."

11. GDC 40, "Testing of Containment Heat Removal 12. GDC 43 , "Testing of Containment Atmosphere 13. GDC 46 , "Testing of cooling Water systems." ment."

14: GDC 54 , "Piping Systems Penetrating Contain-

C. 10 CFR 100, Appendix A, "Seismic and Geologic siting Criteria for Nuclear Power Plants."

$$
3-13
$$


3.9.2 USNRC Regulatory Guides, SRP Branch Technical Positions and Appendices

A. Regulatory Guide 1.20, "Comprehensive Vibration Assessment Program for Reactor Internals During Preoperational and Initial startup Testing."

B. Regulatory Guide 1.26, "Quality Group Classifications and standards for Water-, steam-, and Radioactive-WasteContaining Components of Nuclear Power Plants."

C. Regulatory Guide 1.29, "Seismic Design Classification."

D. Regulatory Guide 1.61, "Damping Values for Seismic Design of Nuclear Power Plants."

E. Regulatory Guide 1.68, "Initial Test Programs for Water-Cooled Nuclear Power Plants."

F. Regulatory Guide 1.92, "Sombining Modal Responses and Spatial Components in Seismic Response Analysis."

G. Regulatory Guide 1.124, "Service Limits and Loading Combinations for Class 1 Linear-Type Component Supports."

H. Regulatory Guide 1.130, "Service Limits and Loading Combinations for Class 1 Plate- and Shell-Type Component supports.".

I. SRP 3.9.3, Appendix A, "Stress Limits for ASME Class 1, 2, and 3 Components and Component supports of SafetyRelated systems and class cs core support structures Under Specified Service Loading Combinations."

\subsubsection{Codes and standards}

A. ANSI B16.5-1977," "Steel Pipe Flanges and Flanged Fittings, steel, Nickel Alloy, and Other Special Alloys." (This standard was revised and issued as ANSI/ASME B16.5-1981, "Pipe Flanges and Flanged Fittings.")

B. ANSI B16.11-1980, "Forged steel Fittings, SocketWelding and Threaded."

C. ANSI B16.34-1977, "Valves, Flanged and Butt-Welding End Steel, Nickel Alloy, and other Special Alloys." (This standard was revised and issued as ANSI B16.34-1988, "Valves-Flanged, Buttwelding and Threaded End.") 
D. ANSI/ASME B16.9-1978, "Factory-Made wrought steel Butt Welding Fittings." (This standard was revised and issued as ANSI/ASME B16.9-1986, "Factory-Made Wrought steel Butt Welding Fittings.")

E. ANSI/ASME B16.25-1979, "Butt Welding Ends." (This standard was revised and issued as ANSI/ASME B16.25-1986, "Butt Welding Ends.")

$$
\begin{aligned}
& \text { F. ANSI/ASME B31.1, "Power Piping." } \\
& \text { G. ASME Boiler and Pressure Vessel Code. }
\end{aligned}
$$

1. Section III, "Rules for construction of Nuclear Power Plant Components," Division I.

2. Section VIII, "Rules for construction of Pressure Vessels," Division 1.

3. Section XI, "Rules for Inservice Inspection of . Nuclear Power Plant Components," subsections IWP and IWV.

Flanges, and Unions."

\subsubsection{Supplemental Information}

1987.

A. NUREG-0800, USNRC "Standard Review Plan," June components." $1 . \quad$ SRP 3.9.1, "Special Topics for Mechanical

2. SRP 3.9.2, "Dynamic Testing and Analysis of Systems, Components, and Equipment."

3. SRP 3.9.3, "ASME Class 1, 2, and 3 Components, Component supports, and core support structures."

nals."

4. SRP 3.9.4, "Control Rod Drive Systems."

5. SRP 3.9.5, "Reactor Pressure Vessel Inter-

Valves."

6. SRP 3.9.6, "Inservice Testing of Pumps and

B. NUREG-0484, "Methodology for Combining Dynamic Responses," USNRC, September 1978.

c. NUREG-0609, "Asymmetric Blowdown Loads on PWR Primary Systems," USNRC, January 1981.

$$
3-15
$$


D. IE Bulletin 79-02, through Rev. 2, "Pipe support Base Plate Designs Using Concrete Expansion Bolts."

E. IE Information Notice 83-80, "Use of Specialized stiff Pipe clamps."

F. "Design Response Spectra for Nuclear Power Plants," N.M. Newmark, J.A. Blume and K.K. Kapur, Journal of the Power Division, American Society of Civil Engineers, pp. 287-303, November 1973.

G. "Spectral Treatment of Actions of Three Earthquake Components on structures," S.L. Chu, M. Amin, and S. Singh, Nuclear Engineering and Design, Vol. 21, pp. 126-136, 1972 .

H. "Fundamentals of Earthquake Engineering," N.M. Newmark and E. Rosenblueth, Prentice Hall, 1971.

3.10 BEIBMIC AND DYNAMIC QOALIFICATION OF MECHANICAL AND ELECTRICAL EQUIPMENT

This section identifies criteria for methods of test and analysis to assure the operability of mechanical and electrical equipment, including instrumentation and control.

\subsubsection{Code of Federal Regulations}

A. 10 CFR 50, Appendix A, "General Design Criteria for Nuclear Power Plants."

1. GDC 1, "Quality standards and Records."

2. GDC 2, "Design Bases for Protection Against Natural Phenomena."

Bases."

3. GDC 4, "Environmental and Missile Design

4. GDC 14, "Reactor Coolant Pressure Boundary."

Boundary."

5. GDC 30, "Quality of Reactor Coolant Pressure

B. 10 CFR 100, Appendix A, "Seismic and Geologic siting. Criteria for Nuclear Power Plants." 
3.10.2 USNRC Regulatory Guides, SRP Branch Technical Positions and Appendices

A. Regulatory Guide 1.61, "Damping Values for Seismic Design of Nuclear Power Plants."

B. Regulatory Guide 1.89, "Environmental Qualification of Certain Electric Equipment Important to safety for Nuclear Power Plants."

C. Regulatory Guide 1.92, "Combining Modal Responses and spatial Components in Seismic Response Analysis."

D. Regulatory Guide 1.100, "Seismic Qualification of Electric and Mechanical Equipment for Nuclear Power Plants."

E. Regulatory Guide 1.148, "Functional Specification for Active Valve Assemblies in Systems Important to Safety in Nuclear Power Plants."

\subsubsection{Codes and standards}

A. ANSI B16.41-1975, "Functional Qualification Requirements for Power Operated Active Valve Assemblies for Nuclear Power Plants." (This standard was revised and issued as ANSI B16.41-1983, "Functional Qualification Requirements for Power Operated Valve Assemblies for Nuclear Power Plants.")

B. ANSI N278.1-1975(R1985), "Self-Operated and PowerOperated Safety-Related Valves Functional specification standard."

C. ANSI/IEEE 323-1974, "IEEE standard for Qualifying Class 1E Equipment for Nuclear Power Generating stations." (This standard was revised and issued as ANSI/IEEE 323-1984, "IEEE Standard for Qualifying Class $1 \mathrm{E}$ Equipment for Nuclear Power Generating stations.")

D. ANSI/IEEE 344-1987, "IEEE Recommended Practice for Seismic Qualification of Class $1 \mathrm{E}$ Equipment for Nuclear Power Generating stations."

\subsubsection{Supplementary Information}

1987.

A: NUREG-0800, USNRC "Standard Review Plan," June

1. SRP 3.10,. "Seismic and Dynamic qualification of Mechanical and Electrical Equipment."

B. NUREG-1030, "Seismic Qualification of Equipment in operating Nuclear Power Plants, "USNRC, February 1987. 

ELECTRICAL EQUIPMENT

This section identifies criteria for the environmental design and qualification of mechanical and electrical equipment, including instrumentation and control, to ensure they are capable of performing their design safety functions.

\subsubsection{Code of Federal Regulations}

A. Commission Policy statement, "Additional Applications of Leak-Before-Break Technology," 54 FR 18649, May 2, 1989.

B. 10 CFR 50.49, "Environmental Qualification of Electrical Equipment Important to safety for Nuclear Power Plants."

C. 10 CFR 50, Appendix A, "General Design Criteria for Nuclear Power Plants."

Bases."

1. GDC 4, "Environmental and Missile Design

D. 10 CFR 50, Appendix B, "Quality Assurance Criteria for Nuclear Power Plants and Fuel Reprocessing Plants."

1. Criterion III, "Design Control."

2. Criterion XI, "Test Control."

3. Criterion XVII, "Quality Assurance Records."

3.11.2 USNRC Regulatory Guides, SRP Branch Technical Positions and Appendices

A. Regulatory Guide 1.40, "Qualification Tests of Continuous Duty Motors Installed Inside the Containment of WaterCooled Nuclear Power Plants."

B. Regulatory Guide 1.63, "Electric Penetration Assemblies in Containment structures for Nuclear Power Plants."

C. Regulatory Guide 1.73, "Qualification Tests of Electric Valve Operators Installed Inside the Containment of Nuclear Power Plants."

D. Regulatory Guide 1.89, "Environmental Qualification of Certain Electrical Equipment Important to safety for Nuclear Power Plants." 
E. Regulatory Guide 1.131, "Qualification Tests of Electric Cables, Field Splices, and Connections for Light-WaterCooled Nuclear Power Plants."

F. Regulatory Guide 1.156, "Environmental Qualification of Connection Assemblies for Nuclear Power Plants."

G. Regulatory Guide 1.158, "Qualification of SafetyRelated Lead storage Batteries for Nuclear Power Plants."

\subsubsection{Codes and standards}

A. ANSI/IEEE 535-1986, "IEEE standard for Qualification of Class $1 \mathrm{E}$ Lead Storage Batteries for Nuclear Power Generating stations."

B. ANSI/IEEE 572-1985, "IEEE standard for Qualification of Class 1E Connection Assemblies for Nuclear Power Generating stations."

C. IEEE 317-1983, "IEEE Standard for Electric Penetration Assemblies in Containment structures for Nuclear Power Generating stations."

D. IEEE 323-1974, "IEEE standard for Qualifying class 1E Equipment Nuclear Power Generating Stations." (This standard was revised and issued as ANSI/IEEE 323-1984, "IEEE standard for Qualifying class 1E Equipment for Nuclear Power Generating stations.")

E. IEEE 334-1971, "Trial-Use Guide for Type Tests of Continuous Duty class 1E Motors Installed Inside the containment of Nuclear Power Generating stations." (This standard was revised and issued as ANSI/IEEE 334-1974(R1982), "IEEE Standard for Type Tests of Continuous Duty Class $1 \mathrm{E}$ Motors for Nuclear Power Generating stations.")

F. IEEE 382-1972, "IEEE Trial-Use Guide for Type Test of Class I Electric Valve operators for Nuclear Power Generating stations." (This standard was revised and issued as ANSI/IEEE 382-1985, "IEEE Standard for Qualification of Actuators for Power operated Valve Assemblies with Safety-Related Functions for Nuclear Power Plants.")

G. IEEE 383-1974(R1982), "IEEE standard for Type Test of Class 1E Electric Cables, Field splices, and Connections for Nuclear Power Generating stations." 


\subsubsection{Bupplementary Information}

A. NUREG-0800, USNRC "Standard Review Plan," June 1987

1. SRP 3.11, "Environmental Qualification of Mechanical and Electrical Equipment."

B. NUREG-0588, "Interim Staff Position on Environmental Qualification of Safety-Related Electrical Equipment," USNRC, July 1981.

c. NUREG-0737, "Clarification of TMI Action Plan Requirements," USNRC, November 1980.

D. NUREG-0718, "Licensing Requirements for Pending Applications for Construction Permits and Manufacturing License," USNRC, March 1981.

E. IE Information Notice 85-39, "Auditability of Electrical Equipment Qualification Records at Licensees' Facilities."

F. IE Information Notice 85-40, "Deficiencies in Equipment Qualification Testing and Certification Process." 
This chapter identifies criteria for establishing the capability of the reactor to perform its safety functions throughout its design lifetime under all normal operational modes, including both transient and steady state, and accident conditions.

\subsection{SUMMARY DESCRIPTION}

This section in an SAR contains a summary description of the mechanical, nuclear, and thermal and hydraulic designs of the various reactor components, including the fuel, reactor vessel internals, and reactivity control systems. No specific NRC criteria are specified for this summary description.

\subsection{FUEL BYSTEM DESIGN}

\subsubsection{Code of Federal Regulations}

A. 10 CFR 50.46, "Acceptance Criteria for Emergency Core cooling systems for Light water Nuclear Power Reactors." Nuclear Power Plants."

B. 10 CFR 50, Appendix A, "General Design Criteria for

1. GDC 10, "Reactor Design."

Capability."

2. GDC 27, "Combined Reactivity Control Systems

3. GDC 35, "Emergency Core Cooling."

C. 10 CFR 50, Appendix K, "ECCS Evaluation Models."

D. 10 CFR 100.11, "Determination of Exclusion Area, Low Population Zone, and Population Center Distance."

\subsubsection{USNRC Regulatory Guides, SRP Branch Technical Positions and Appendices}

The method of calculating $x / Q$ values in Regulatory Guides $1.3,1.4,1.25$, and 1.77 is superseded by the method presented in Regulatory Guide 1.145, "Atmospheric Dispersion Models for Potential Accident Consequence Assessments at Nuclear Power Plants." 
A. Regulatory Guide 1.3, "Assumptions Used for Evaluating the Potential Radiological Consequences of a Loss-ofCoolant Accident for Boiling Water Reactors."

B. Regulatory Guide 1.4, "Assumptions Used for Evaluating the Potential Radiological Consequences of a Loss-ofCoolant Accident for Pressurized Water Reactors."

C. Regulatory Guide 1.25, "Assumptions Used for Evaluating the Potential Radiological Consequences of a Fuel Handling Accident in the Fuel Handling and storage Facility for Boiling and Pressurized Water Reactors."

D. Regulatory Guide 1.60, "Design Response Spectra for Seismic Design of Nuclear Power Plants."

E. Regulatory Guide 1.77, "Assumptions Used for Evaluating a Control Rod Ejection Accident for Pressurized Water Reactors."

F. Regulatory Guide 1.126, "An Acceptable Model and Related statistical Methods for the Analysis of Fuel Densification."

G. Regulatory Guide 1.145, "Atmospheric Dispersion Models for Potential Accident Consequence Assessments at Nuclear Power Plants."

H. Regulatory Guide 2.3, "Quality Verification for Plate-Type Uranium-Aluminum Fuel Elements for Use in Research Reactors."

I. SRP 4.2, Appendix A, "Evaluation of Fuel Assembly Structural Responses to Externally Applied Forces."

\subsubsection{Codes and standards}

A. ANSI N398-1974, "Quality Verification for PlateType Uranium-Aluminum Fuel Elements." (This standard was revised and issued as ANSI/ANS 15.2-1974(R1982), "Quality Control for Plate-Type Uranium-Aluminum Fuel Elements.")

B. ASME Boiler and Pressure Vessel Code, Section III, "Rules for Construction of Nuclear Power Plant Components," Division 1 .

C. ASTM C776-1983, "Standard specification for Sintered Uranium Dioxide Pellets." (This standard was revised and issued as ASTM C776-1986, "Specification for Sintered Uranium Dioxide Pellets.") 


\subsubsection{Supplemental Material}

1987.

A. NUREG-0800, USNRC "standard Review Plan," June

$$
\text { 1. SRP 4.2, "Fuel System Design." }
$$

B. NUREG-0630, "Cladding Swelling and Rupture Models for LOCA Analysis," USNRC, April 1980.

C. NUREG-0401, "Fuel Failure Detection in Operating Reactors," USNRC, March 1978. USNRC, JulY 1976 .

D. NUREG-0085, "The Analysis of Fuel Densification,"

E. NUREG/CR-1883, "Multirod Burst Test Program Progress Report for January-June 1980," R.H. Chapman, Oak Ridge National Laboratory, March 1981.

F. NUREG/CR-1380, "Assessment of current onsite Inspection Techniques for LWR Fuel Systems," W.J. Bailey, et al., Battelle Pacific Northwest Laboratory, Vol. 1 July 1980, Vol. 2, January 1981.

G. WASH-1236, "Technical Report on Densification of light Water Reactor Fuels," USAEC, November 14, 1972.

H. "Burst Criterion of zircaloy Fuel claddings in a LOCA," F. Erbacher, H.J. Neitzel, H. Rosinger, H. Schmidt, and K. Wiehr, ASTM Fifth International Conference on zirconium in the Nuclear Industry, August 4-7, 1980, Boston, Massachusetts.

I. BNWL-1898, "GAPCON-THERMAL-2: A Computer Program for calculating the Thermal Behavior of an oxide Fuel Rod," C.E. Beyer, C.R. Hann, D.D. Lanning, F.E. Panisko and L.J. Parchen, Battelle Pacific Northwest Laboratory, November 1975.

J. BNWL-1897, "User's Guide for GAPCON-THERMAL-2: A Computer Program for Calculating the Thermal Behavior of an oxide Fuel Rod," C.E. Beyer, C.R. Hann, D.D. Lanning, F.E. Panisko and L.J. Parchen, Battelle Pacific Northwest Laboratory, November 1975.

K. ANL-6548, "Studies of Metal-Water Reactions at High Temperatures, III. Experimental and Theoretical studies of the Zirconium-Water Reaction,".L. Baker and L.C. Just, Argonne National Laboratory, May 1962: 
4.3 NOCLEAR DESIGN

\subsubsection{Code of Federal Regulations}

A. Commission Policy Statement, "Use of High-Enriched Uranium (HEU) in Research Reactors," 47 FR 37007, August 24, 1982 .

B. 10 CFR 50.64; "Limitations on the Use of Highly Enriched Uranium (HEU) in Domestic Nonpower Reactors."

Nuclear Power Plants."

C. 10 CFR 50, Appendix A, "General Design Criteria for

1. GDC 10, "Reactor Design."

2. GDC 11, "Reactor Inherent Protection."

lation."

3. GDC 12, "Suppression of Reactor Power Oscil-

4. GDC 13, "Instrumentation and Control."

5. GDC 20, "Protection System Functions."

6. GDC 25, "Protection System Requirements for Reactivity Control Malfunctions."

7. GDC 26, "Reactivity control system Redundancy and Capability."

Capability."

8. GDC 27, "Combined Reactivity Control systems

9. GDC 28, "Reactivity Limits."

4.3.2 USNRC Regulatory Guides, 8RP Branch Technical Positions and Appendices

None.

4.3.3 Codes and standards

None.

4.3.4 Bupplemental Information

1987.

A. NUREG-0800, USNRC "Standard Review Plan," June

1. SRP 4.3, "Nuclear Design."

$$
\text { 4-4 }
$$


B. NUREG-0085, "The Analysis of Fuel Densification," USNRC, JulY 1976.

C. BNL-50274 (ENDF-102), "Data Formats and Procedures for the ENDF Neutron Cross section Library," M.K. Drake, ed., National Neutron Cross section Center, Brookhaven National Laboratory, 1970 .

\subsection{THERMAL AND HYDRAOLIC DEBIGN}

4.4.1 Code of Federal Regulations

A. 10 CFR 50, Appendix A, "General Design Criteria for Nuclear Power Plants."

$$
\text { 1. GDC 10, "Reactor Design." }
$$

4.4.2 USNRC Regulatory Guides, 8RP Branch Technical Positions and Appendices

A. Regulatory Guide 1.68, "Initial Test Programs for Water-Cooled Nuclear Power Plants."

B. Regulatory Guide 1.133, "Loose Parts Detection Program for the Primary Systems of Light-Water-Cooled Reactors."

\subsubsection{Codes and standards}

None.

\subsubsection{Supplemental Information}

1987 .

A. NUREG-0800, USNRC "Standard Review Plan," June

1. SRP 4.4;" "Thermal and Hydraulic Design."

B. NUREG-0718, "Iicensing Requirements for Pending Applications for Construction Permits and Manufacturing License," Item II.F.2, USNRC, March 1981.

C. NUREG-0737, "clarification of TMI Action Plan Requirements," Item II.F.2, USNRC, November 1980.

\subsection{REACTOR MATERIALs}

This section identifies criteria for control rod drive system structural materials and reactor internal materials.

$$
4-5
$$




\subsubsection{Code of Federal Regulations}

A. $\quad 10$ CFR 50.55a, "Codes and Standards."

B. 10. CFR 50, Appendix A, "General Design Criteria for Nuclear Plants."

1. GDC 1, "Quality standards and Records."

2. GDC 14, "Reactor Coolant Pressure Boundary."

3. GDC 26, "Reactivity control system Redundancy and Capability."

4.5.2 U8kRC Regulatory Guides, BRP Branch Technical Positions and Appendices

A. Regulatory Guide 1.31, "Control of Ferrite Content in Stainless steel Weld Metal."

B. Regulatory Guide 1.37, "Quality Assurance Requirements for cleaning of Fluid Systems and Associated Components of Water-Cooled Nuclear Power Plants."

c. Regulatory Guide 1.44, "Control of the Use of Sensitized stainless steel."

D. Regulatory Guide 1.85, "Materials Code Case Acceptability-ASME Section III, Division 1."

\subsubsection{Codes and standards}

A. ANSI N45.2.1-1973, "Cleaning of Fluid systems and Associated Components During Construction Phase of Nuclear Power Plants." (This standard was withdrawn on November 21,1985 and incorporated into ANSI/ASME NQA-2-1986, "Quality Assurance Requirements for Nuclear Power Plants")

B. ASME Boiler and Pressure Vessel Code.

1. Section II, "Material Specifications."

2. Section III, "Rules for construction of Nuclear Power Plant Components," Division 1.

3. Section XI, "Rules for Inservice Inspection of Nuclear Power Plant Components."

C. ASTM A262-86, "Practices for Detecting susceptibility to Intergranular Attack in Austenitic stainless steels.

$$
4-6
$$


D. ASTM A708-79, "Standard Recommended Practices for Detection of susceptibility to Intergranular stress corrosion in Severely sensitized Austenitic stainless steel."

E. AWS A4.2-1974 "standard Procedures for Calibrating Magnetic Instruments to Measure the Delta Ferrite Content of Austenitic stainless steel Weld Metal." (This standard has been revised and issued as ANSI/AWS A4.2-1986, "Procedures for Calibrating Magnetic Instruments to Measure the Delta Ferrite Content of Austenitic Stainless steel Weld Metal.")

F. AWS A5.4-1978, "Specification for CorrosionResisting Chromium and Chromium Nickel steel covered Welding Electrodes." (This standard has been revised and issued as ANSI/AWS A5.4-1981, "Specification for corrosion-Resisting Chromium and Chromium Nickel steel Welding Electrodes.")

\subsection{4 supplemental Information}

1987.

A. NUREG-0800, USNRC "Standard Review Plan," June tural Materials."

port Materials."

2. SRP 4.5.2, "Reactor Internal and Core sup-

\subsection{FUNCTIONAL DESIGN OF REACTIVITY CONTROL SYSTEMS}

\subsubsection{Code of Federal Regulations}

Nuclear Power Plants."

A. 10 CFR 50, Appendix A, "General Design Criteria for

1. GDC 23, "Protection System Failure Modes."

2. GDC 25, "Protection system Requirements for Reactivity Control Malfunctions."

Redundancy and Capability."

"Reactivity control system tems Capability." GDC 27, "Combined Reactivity Control sys-

5. GDC 28, "Reactivity Limits."

6. GDC 29, "Protection Against Anticipated Operational Occurrences." 
4.6.2 U8NRC Regulatory Guides, SRP Branch Technical Positions and Appendices

None.

4.6.3 Codes and standards

None.

4.6.4 supplemental Information

1987 .

A. NUREG-0800, USNRC "Standard Review Plan," June Drive system." $1 . \quad$ SRP 4.6, "Functional Design of Control Rod 
CHAPTER 5

\section{REACTOR COOLANT BYSTEM AND CONNECTED SYSTEMS}

This chapter identifies criteria for the reactor coolant system and connected systems out to and including isolation valving (the reactor coolant pressure boundary).

\subsection{SUMMARY DESCRIPTION}

This section in a SAR contains a summary description of the reactor coolant system and its components. The summary description should include how the relevant requirements of GDC 1 , "Quality standards and Records," 10 CFR 55a, "Codes and Standards," and Regulatory Guide 1.26, "Quality Group Classifications and standards" are met.

\subsection{INTEGRITY OF REACTOR COOLANT PRESSURE BOUNDARY}

This section identifies criteria for overpressure protection, reactor coolant pressure boundary materials, inservice inspection and testing, and the detection of leakage from the reactor coolant pressure boundary.

\subsubsection{Code of Federal Regulations}

A. Commission Policy statement, "Additional Applications of Leak-Before-Break Technology," 54 FR 18649, May 2, 1989.

B. 10 CFR 50.2, "Definitions."

c. 10 CFR 50.55a, "Codes and standards."

D. 10. CFR 50.60, "Acceptance Criteria for Fracture Prevention Measurements for Light Water Nuclear Power Reactors for Normal Operation.":

E. 10 CFR 50, Appendix A, "General Design Criteria for Nuclear Power Plants."

1. GDC 1, "Quality Standards and Records."

2. GDC 2,"Design Basis for Protection Against Natural Phenomena."

Bases."

3. GDC 4, "Environmental and Missile Design 
Boundary."

4. GDC 14, "Reactor Coolant Pressure Boundary."

5. GDC 15, "Reactor Coolant system Design."

6. GDC 30, "Quality of Reactor Coolant Pressure

7. GDC 31, "Fracture Prevention of Reactor Coolant Pressure Boundary."

8. GDC 32, "Inspection of Reactor Coolant Pressure Boundary."

ments."

F. 10 CFR 50, Appendix G, "Fracture Toughness Require-

G. 10 CFR 50, Appendix H, "Reactor Vessel Material Surveillance Program Requirements."

5.2.2 UsNRC Regulatory Guides, SRP Branch Technical Positions and Appendices

A. Regulatory Guide 1.26, "Quality Group Classifications and standards for Water-, steam-, and Radioactive Wastecontaining Components of Nuclear Power Plants."

cation."

B. Regulatory Guide 1.29, "Seismic Design Classifi-

c. Regulatory Guide 1.31, "Control of Ferrite Content in stainless steel Weld Metal."

Weld Properties."

D. Regulatory Guide 1.34, "Control of Electroslag

E. Regulatory Guide 1.36, "Nonmetallic Thermal Insulation for Austenitic Stainless Steel."

F. Regulatory Guide 1.37, "Quality Assurance Requirements for Cleaning of Fluid Systems and Associated Components of Water-Cooled Nuclear Power Plants."

G. Regulatory Guide 1.43, "Control of stainless steel Weld Cladding of Low-Alloy steel Components."

H. Regulatory Guide 1.44, "Control of the Use of Sensitized stainless steel."

I. Regulatory Guide 1.45, "Reactor Coolant Pressure Boundary Leakage Detection Systems." 
J. Regulatory Guide 1.50, "Control of Preheat Temperature for Welding of Low-Alloy Steel."

K. Regulatory Guide 1.71, "Welder Qualification for Areas of Limited Accessibility."

L. Regulatory Guide 1.84, "Design and Fabrication Code Case Acceptability in ASME Section III, Division 1."

M. Regulatory Guide 1.85, "Materials code case Acceptability in ASME Section III, Division 1."

N. Regulatory Guide 1.87, "Guidance for Construction of Class 1 Components in Elevated Temperature Reactors" (Supplement to ASME section III Code Cases 1592, 1593, 1594, 1595 and 1596)."

0. Regulatory Guide 1.147, "Inservice Inspection Code Case Acceptability, ASME Section XI, Division 1."

P. SRP 5.2, Branch Technical Position RSB 5-2, "Overpressurization Protection of Pressurized Water Reactors While Operating at Low Temperatures."

\subsubsection{Codes and standards}

A. ANSI N45.2.1-1973, "Cleaning of Fluid Systems and Associated Components During Construction Phase of Nuclear Power Plants." (This standard was withdrawn November 21, 1985 and incorporated into ANSI/ASME NQA-2-1986, "Quality Assurance Requirements for Nuclear Power Plants.")

B. ASME Boiler and Pressure Vessel Code.

1. Section II, "Material Specifications."

2. Section III, "Rules for construction of Nuclear Power Plant Components," Division 1.

3. Section IX, "Qualification standard for Welding and Brazing procedures, Welders, Brazers, and Welding and Brazing operators."

4. Section XI, "Rules for Inservice Inspection of Nuclear Power Plant Components.":

5. "Code Cases, Nuclear components."

C. ASTM A-262-86, "Practices for Detecting susceptibility to Intergranular Attack in Austenitic stainless Steel," Practice E. 
D. AWS A4.2-1974, "Standard Procedures for Calibrating Magnetic Instruments to Measure the Delta Ferrite content of Austenitic stainless steel Weld Metal." (This standard was revised and issued as ANSI/AWS A4.2-1986, "Procedures for Calibrating Magnetic Instruments to Measure the Delta Ferrite Content of Austenitic stainless steel Weld Metals.")

E. AWS A5.4-1978, "Specification for CorrosionResisting Chromium and Chromium Nickel steel covered Welding Electrodes." (This standard was revised and issued as ANSI/AWS A5.4-1981, "Specification for Corrosion-Resisting Chromium and Chromium Nickel steel Welding Electrodes.")

5.2.4 supplementary Information

1987.

A. NUREG-0800, USNRC "Standard Review Plan," June

1. SRP 5.2.2, "Overpressure Protection."

ary Materials."

3. SRP 5.2.4, "Reactor Coolant Pressure Boundary Inservice Inspection and Testing."

ary Leakage Detection."

4. SRP 5.2.5, "Reactor Coolant Pressure Bound-

B. NUREG-0718, "Licensing Requirements for Pending Applications for Construction Permits and Manufacturing License," Items II.D.1 and II.D.3, USNRC, March 1981.

c. NUREG-0737, "Clarification of TMI Action Plan Requirements;" Items II.D.1 and II.D.3, USNRC, November 1980 .

D. NUREG-0224, "Final Report on Reactor Vessel Pressure Transient Protection for Pressurized Water Reactors," USNRC, September 1978 .

E. IE Bulletin 82-02," "Degradation of Threaded Fasteners in the Reactor coolant Pressure Boundary of PWR Plants."

F. Information Notice 82-06, "Failure of Steam Generator Primary side Manway closure studs." 
This section identifies criteria for the materials, pressure-temperature limits, and integrity of the reactor vessel.

\subsubsection{Code of Federal Regulations}

A. 10 CFR 50.55a, "Codes and Standards."

B. 10 CFR 50.60, "Acceptance Criteria for Fracture Prevention Measurements for Light-Water Nuclear Power Reactors for Normal Operation."

C. 10 CFR 50.61, "Fracture Toughness Requirements for Protection Against Pressurized Thermal Shock Events."

D. 10 CFR 50, Appendix A, "General Design Criteria for Nuclear Power Plants."

Bases."

1. GDC 1, "Quality standards and Records."

2. GDC 4, "Environmental and Missile Design

3. GDC 14, "Reactor Coolant Pressure Boundary."

Boundary."

4. GDC 30, "Quality of Reactor coolant Pressure

5. GDC 31, "Fracture Prevention of the Reactor Coolant Pressure Boundary."

sure Boundary."

6. GDC 32, "Inspection of Reactor Coolant Pres-

E. 10 CFR 50, Appendix B, "Quality Assurance Criteria for Nuclear Power Plants and Fuel Reprocessing Plants."

ments."

F. 10 CFR 50, Appendix G, "Fracture Toughness Require-

G. 10 CFR 50, Appendix H, "Reactor Vessel Material Surveillance Program Requirements."

5.3.2 USNRC Regulatory Guides, SRP Branch Technical Postions and Appendices

A. Regulatory Guide 1.2, "Thermal shock to Reactor Pressure Vessels."

B. Regulatory Guide 1.31, "Control of Ferrite Content in Stainless steel Weld Metal." 
Weld Properties."

D. Regulatory Guide 1.37, "Quality Assurance Requirements for Cleaning of Fluid Systems and Associated Components of Water-Cooled Nuclear Power Plants."

E. Regulatory Guide 1.43, "Control of stainless Steel Weld Cladding of Low-Alloy Steel Components."

F. Regulatory Guide 1.44, "Control of the Use of Sensitized Stainless Steel."

G. Regulatory Guide 1.50, "Control of Preheat Temperature for Welding of Low-Alloy steel."

H. Regulatory Guide 1.65, "Materials and Inspections for Reactor Vessel Closure studs."

I. Regulatory Guide 1.71, "Welder Qualification for Areas of Limited Accessibility."

J. Regulatory Guide 1.99, "Effects of Residual Elements on Predicting Radiation Damages to Reactor Vessel Materials."

K. Regulatory Guide 1.150, "Ultrasonic Testing of Reactor Vessel Welds During Preservice and Inservice Examinations."

L. Regulatory Guide 1.154, "Format and content of Plant-Specific Pressurized Thermal Shock Safety Analysis Reports for Pressurized Water Reactors."

M. SRP 5.3.2, Branch Technical Position MTEB 5-2, "Fracture Toughness Requirements."

\subsubsection{Codes and standards}

A. ANSI N45.2.1-1973, "Cleaning of Fluid Systems and Associated Components During Construction Phase of Nuclear Power Plants." (This standard was withdrawn November 21, 1985 and incorporated into ANSI/ASME NQA-2-1986, "Quality Assurance Requirements for Nuclear Power Plants.")

B. ASME Boiler and Pressure Vessel code.

1. Section II, "Material Specifications."

2. Section III, "Rules for construction of Nuclear Power Plant Components," Division 1.

$$
\text { 5-6 }
$$


3. Section V, "Nondestructive Examination."

4. Section IX, "Qualification standard for Welding and Brazing Procedures, Welders, Brazers, and Welding and Brazing Operators."

5. Section XI, "Rules for Inservice Inspection of Nuclear Power Plant Components."

C. ASTM A-262-86, "Practices for Detecting susceptibility to Intergranular Attack in Austenitic stainless steels," Practice $A$ and $E$.

D. ASTM E-185-73, "Surveillance Tests on structural Materials in Nuclear Reactors." (This standard was revised and issued as ASTM E-185-82, "Practice for Conducting surveillance Tests for Light-Water-Cooled Nuclear Power Reactor Vessels.")

E. AWS A4.2-1974, "Standard Procedures for Calibrating Magnetic Instruments to Measure the Delta Ferrite Content of Austenitic stainless steel Weld Metal." (This standard was revised and issued as ANSI/AWS A4.2-86, "Procedures for Calibrating Magnetic Instruments to Measure the Delta Ferrite Content of Austenitic Stainless steel Weld Metals.")

F. AWS A5.4-1978, "Specification for CorrosionResisting Chromium and:Chromium Nickel steel covered Welding Electrodes." (This standard has been revised and issued as ANSI/AWS A5.4-1981, "Specification for Corrosion-Resisting Chromium and Chromium Nickel steel Welding Electrodes.")

\subsubsection{Supplemental Information}

1987.

A. NUREG-0800, USNRC, "Standard Review Plan," June

1. SRP 5.3.1, "Reactor Vessel Materials."

2. SRP 5.3.2, "Pressure-Temperature Limits."

3. SRP 5.3.3, "Reactor Vessel Integrity."

B. NUREG-0744, Rev. 1, "Resolution of Task A-11 Reactor Vessel Material Toughness Safety Issue," Vol. 1 and 2, USNRC, October 1982 . 


\subsection{COMPONENT AND SUBSYBTEM DESIGN}

This section identifies criteria for the design of the following components and subsystems of the reactor coolant system:

Integrity of the Pump Flywheel

steam Generator Materials

Inservice Inspection of the steam Generator Tube

Reactor Core Isolation Cooling System

Residual Heat Removal system

Reactor water cleanup system

Pressurizer Relief Tank

High Point Vents of the Reactor Coolant system

\subsubsection{Code of Federal Regulations}

A. 10 CFR 50.46, "Acceptance Criteria for Emergency core cooling systems for Light water Nuclear Power Reactors."

B. 10 CFR 50.55a, "Codes and Standards."

C. 10 CFR 50, Appendix A, "General Design Criteria for Nuclear Power Plants."

1. GDC 1, "Quality standards and Records."

Natural Phenomena."

2. GDC 2, "Design Bases for Protection Against

3. GDC 4, "Environmental and Missile Design

Bases."

Components."

4. GDC 5, "Sharing of structures, systems, and

5. GDC 14, "Reactor Coolant Pressure Boundary."

6. GDC 15, "Reactor Coolant System Design."

7. GDC 19, "Control Room."

8. GDC 29, "Protection Against Anticipated Operational Occurrences." 
Boundary."

9. GDC 30, "Quality of Reactor Coolant Pressure

10. GDC 31, "Fracture Prevention of the Reactor Coolant Pressure Boundary."

sure Boundary." 11 . GDC 32, "Inspection of Reactor Coolant Pres-

12. GDC 33, "Reactor Coolant Makeup."

13. GDC 34, "Residual Heat Removal."

ment."

14. GDC 54, "Piping Systems Penetrating Contain-

16. GDC 56, "Primary Containment Isolation."

17. GDC 57, "Closed System Isolation Valves."

18. GDC 60, "Control of Releases of Radioactive Materials to the Environment."

Radioactivity Control."

61, "Fuel storage and Handling and

D. 10 CFR 50, Appendix B, "Quality Assurance Criteria for Nuclear Power Plants and Fuel Reprocessing Plants."

5.4.2 USNRC Regulatory Guides, SRP Branch Technical Positions and Appendices

A. Regulatory Guide 1.1, "Net Positive Suction Head for Emergency Core Cooling and Containment Heat Removal System Pumps."

wheel Integrity."

B. Regulatory Guide 1.14, "Reactor Coolant Pump Fly-

c. Regulatory Guide 1.22, "Periodic Testing of Protection System Actuation Functions."

D. Regulatory Guide 1.26 , "Quality Group Classifications and standards for Water-, Steam-, and Radioactive-WasteContaining Components of Nuclear Power Plants.": cation."

E. Regulatory Guide 1.29, "Seismic Design Classifi- 
F. Regulatory Guide 1.37, "Quality Assurance Requirements for cleaning of Fluid Systems and Associated Components of Water-Cooled Nuclear Power Plants."

G. Regulatory Guide 1.53, "Application of the single Failure Criterion to Nuclear Power Plant Protection Systems."

H. Regulatory Guide 1.56," Maintenance of Water Purity in Boiling Water Reactors."

I. Regulatory Guide 1.68, "Initial Test Programs for Water-Cooled Nuclear Power Plants."

J. Regulatory Guide 1.83, "Inservice Inspection of Pressurized Water Reactor steam Generator Tubes."

K. Regulatory Guide 1.85, "Materials code Case Applicability, ASME Section III, Division 1."

L. Regulatory Guide 1.92, "Combining Modal Responses and spatial Components in Seismic "Response Analysis."

Heat Removal."

M. Regulatory Guide 1.139, "Guidance for Residual

N. SRP 5.4.2.1, Branch Technical Position MTEB 5-3, "Monitoring of Secondary side Water Chemistry in PWR Steam Generators."

O. SRP 5.4.7, Branch Technical Position RSB 5-1, "Design Requirements of the Residual Heat Removal System."

\subsection{3 codes and standards}

A. ANSI N45.2.1-1973, "Cleaning of Fluid systems and Associated Components During Construction Phase of Nuclear Power Plants." (This standard was withdrawn November 21, 1985 and incorporated into ANSI/ASME NQA-2-1986, "Quality Assurance Requirements for Nuclear Power Plants.")

B. ASME Boiler and Pressure Vessel Code.

1. Section II, "Material Specifications."

2. Section III, Division 1, "Rules for Construction of Nuclear Power Plant Components,"

3. Section IX, "Qualification Standard for Welding and Brazing Procedures, Welders, Brazers, and Welding and Brazing operators." 
4. Section XI, "Rules for Inservice Inspection of Nuclear Power Plant Components."

5. "Code Cases, Nuclear Components."

C. ASNT-SNT-TC-1A, "Nondestructive Testing Personnel Qualification and certification."

D. ASTM A370-86, "Test Methods and Definitions for Mechanical Testing of Steel Products."

E. ASTM E208-85, "Method for Conducting Drop-Weight Tests to Determine Nil-Ductility Transition Temperature of Ferritic steels."

F. IEEE 338-1987, "IEEE Standard Criteria for the Periodic Surveillance Testing of Nuclear Power Generating stations Class 1E Power and Protection systems."

G. IEEE 379-1977, "IEEE Standard Application of the Single-Failure criterion to Nuclear Power Generating station Class 1E systems." (This standard was revised and issued as ANSI/IEEE 379-1988, "IEEE Standard Application of the SingleFailure Criterion to Nuclear Power Generating station Class $1 \mathrm{E}$ systems.")

\subsubsection{Supplemental Information}

1987.

A. NUREG-0800, USNRC, "Standard Review Plan," June

(PWR) ."

1. SRP 5.4.1.1, "Pump Flywheel Integrity,

2. SRP 5.4.2.1, "Steam Generator Materials."

3. SRP 5.4.2.2, "Steam Generator Tube Inservice

Inspection."

(BWR) . "

4. SRP 5.4.6," "Reactor Core Isolation Cooling,

tem."

5. SRP 5.4.7, "Residual Heat Removal (RHR) Sys-

(BWR) . "

6. SRP 5.4.8, "Reactor water cleanup system,

7. SRP 5.4.11, "Pressurizer Relief Tank." 
Point Vents." ${ }^{8 .}$ SRP 5.4.12, "Reactor coolant System High

B. NUREG-0718, "Licensing Requirements for Pending Applications for Construction Permits and Manufacturing License," USNRC, March 1981.

C. NUREG-0737, "Clarification of TMI Action Plan Requirements," USNRC, November 1980.

D. NUREG-0660, "NRC Action Plan Developed as a Result of the TMI-2 Accident," USNRC, Vol. 1, May 1980 and Vol. 1, Rev. 1 , August 1980 . 
CHAPTER 6

ENGINEERED SAFETY FEATURES

This chapter identifies criteria for the engineered safety features addressed in Regulatory Guide 1.70 that are commonly used to limit the consequences of postulated accidents in light-water-cooled power reactors.

\section{1 \\ ENGINEERED SAFETY FEATURE MATERIALS}

\subsubsection{Code of Federal Regulations}

A. 10 CFR 50.55a, "Codes and standards."

B. 10 CFR 50, Appendix A, "General Design Criteria for Nuclear Power Plants."

Bases."

1. GDC 1, "Quality standards and Records."

2. GDC 4, "Environmental and Missile Design

3. GDC 14, "Reactor Coolant Pressure Boundary."

4. GDC 31, "Fracture Prevention of Reactor Coolant Pressure Boundary."

5. GDC 35, "Emergency Core Cooling."

6. GDC 41, "Containment Atmosphere Cleanup."

Pressure Boundary."

7. GDC 51, "Fracture Prevention of Containment

C. 10 CFR 50, Appendix B, "Quality Assurance Criteria for Nuclear Power Plants and Fuel Reprocessing Plants."

6.1.2 USNRC Regulatory Guides, SRP Branch Technical Positions and Appendices

A. Regulatory Guide 1.7, "Control of Combustible Gas Concentrations in Containment Following a Loss-of-Coolant Accident."

B. Regulatory Guide 1.31, "Control of Ferrite Content in stainless steel Weld Metal."

C. Regulatory Guide 1.36, "Nonmetallic Thermal Insulation for Austenitic stainless Steel." 
D. Regulatory Guide 1.37, "Quality Assurance Requirements for cleaning of Fluid systems and Associated Components of Water-Cooled Nuclear Power Plants."

E. Regulatory Guide 1.44, "Control of the Use of Sensitized stainless steel."

F. Regulatory Guide 1.50, "Control of Preheat Temperature for Welding of Low-Alloy steel."

G. Regulatory Guide 1.54, "Quality Assurance Requirements for Protective Coatings Applied to Water-cooled Nuclear Power Plants."

H. SRP 5.2.3, Branch Technical Position MTEB 5-7, "Material selection and Processing Guidelines for BWR Coolant Pressure Boundary Piping."

I. SRP 6.1.1, Branch Technical Position MTEB 6-1, "pH for Emergency Coolant Water for PWRs."

\subsubsection{Codes and standards}

A. ANSI 45.2.1-1973, "Cleaning of Fluid systems and Associated Components During Construction Phase of Nuclear Power Plants." (This standard was withdrawn November 21, 1985 and incorporated into ANSI/ASME NQA-2-1986, "Quality Assurance Requirements for Nuclear Power Plants.")

B. ANSI N101.2-1972,' "Protective coatings (Paints) for Light water Nuclear Reactor containment Facilities." (This standard was withdrawn in 1983; it was replaced by the "Manual of coating work for Light-Water Nuclear Power Plant Primary Containment and other Safety-Related Facilities," ASTM, 1979.)

C. ANSI N101.4-1972, "Quality Assurance for Protective Coatings Applied to Nuclear Facilities." (This standard was withdrawn in 1983; it was replaced by the "Manual of coating Work for Light-Water Nuclear Power Plant Primary Containment and other Safety-Related Facilities," ASTM, 1979.)

D. ASME Boiler and Pressure Vessel Code.

1. Section II, "Material specifications."

2. Section III, "Rules for construction of Nuclear Power Plant Components," Division 1 and Division 2 .

3. Section IX, "Qualification standard for Welding and Brazing Procedures, Welders, Brazers, and Welding and Brazing Operators." 
E. ASTM A262-86, "Practices for Detecting susceptibility to Intergranular Attack in stainless steel."

F. AWS A4.2-1974, "Standard Procedures for Calibrating Magnetic Instruments to Measure the Delta Ferrite content of Austenitic stainless steel Weld Metal." (This standard was revised and issued as ANSI/AWS A4.2-1986, "Procedures for Calibrating Magnetic Instruments to Measure the Delta Ferrite Content of Austenitic stainless steel Weld Metals.")

G. AWS A5.4-1978, "Specification for corrosionResisting Chromium and Chromium Nickel steel covered Welding Electrodes." (This standard was revised and issued as ANSI/AWS A5.4-1981, "Specification for Corrosion-Resisting Chromium and Chromium Nickel steel Welding Electrodes.")

\subsubsection{Supplemental Information}

1987.

A. NUREG-0800, USNRC "Standard Review Plan," June

Materials."

1. SRP 6.1.1, "Engineered safety Features

2. SRP 6.1.2, "Protective coating systems (Paints) Organic Materials."

B. WASH-1233, "Review of Organic Iodide Formation Under Accident Conditions in Water-Cooled Reactors," USAEC, 1972.

C. "Manual of coating Work for Light-Water Nuclear Power Plant Primary containment and other safety-Related Facilities," ASTM, 1979.

D. "Post-Accident Hydrogen Generation from Protective Coatings in Power Reactors," H.E. Zittel, Nuclear Technology, Volume 17, pp. 143-146, 1973 .

E. "Radiation Effects on Organic Materials," R.0. Bolt and J.G. Carroll, Academic. Press, New York, 1963.

\subsection{CONTAINMENT SYBTEMS}

This section identifies criteria for containment functional design, containment heat removal systems, secondary containment functional design, containment isolation system, combustible gas control in containment, containment leakage testing, and fracture prevention of the containment pressure boundary. 


\subsubsection{Code of Federal Regulations}

Information."

A. 10 CFR 50.34, "Contents of Applications, Technical

B. 10 CFR 50.44, "Standards for Combustible Gas control system in Light-Water-Cooled Power Reactors."

c. 10 CFR 50.46, "Acceptance Criteria for Emergency Core Cooling systems for Light water Nuclear Power Reactors."

(

D. 10 CFR 50.54, "Conditions of Licenses."

E. 10 CFR 50, Appendix A, "General Design Criteria for Nuclear Power Plants."

1. GDC 1, "Quality standards and Records."

2. GDC 2, "Design Bases for Protection Against Natural Phenomena."

Basis."

3. GDC 4, "Environmental and Missile Design

Components."

4. GDC 5, "Sharing of structures, Systems, and

5. GDC 13, "Instrumentation and Control.",

6. GDC 16, "Containment Design."

7. GDC 38, "Containment Heat Removal."

Remọval system."

8. GDC 39, "Inspection of containment Heat system."

9. GDC 40, "Testing of Containment Heat Removal

10. GDC 41, "Containment Atmosphere Cleanup."

Systems."

11. GDC 42, "Inspection of Containment cleanup

12. GDC 43, "Testing of Containment Atmosphere cleanup system."

13. GDC 50, "Containment Design Basis."

14. GDC 51, "Fracture Prevention of Containment Pressure Boundary." 
Rate 15. GDC 52, "Capability for Containment Leakage

16. GDC 53, "Provisions for containment Testing and Inspection."

17. GDC 54, "Piping systems Penetrating containment."

18. GDC 55, "Reactor Coolant Pressure Boundary Penetrating containment."

19. GDC 56," "Primary Containment Isolation."

20. GDC 57, "Closed Systems Isolation Valves."

21. GDC 64, "Monitoring Radioactivity Releases."

F. 10 CFR 50, Appendix J, "Primary Reactor Containment Leakage Testing for Water-Cooled Power Reactors."

G. 10 CFR 50, Appendix K, "ECCS Evaluation Models."

H. 10 CFR 100.11, "Determination of Exclusion Area, Low Population Zone, and Population Center Distance."

\subsubsection{USNRC Regulatory Guides, SRP Branch Technical Positions and Appendices}

The method of calculating $x / Q$ values in Regulatory Guides 1.3 and 1.4 is superseded by the method presented in Regulatory Guide 1.145, "Atmospheric Dispersion Models for Potential Accident Consequence Assessments at Nuclear Power Plants."

A. Regulatory Guide 1.1, "Net Positive Suction Head for Emergency Core cooling and Containment Heat Removal system Pumps."

B. Regulatory Guide 1.3,"Assumptions Used for Evaluating the Potential Radiological Consequences of a Loss-ofCoolant Accident for. Boiling Water Reactors."

C. Regulatory Guide 1.4, "Assumptions Used for Evaluating the Potential Radiological Consequences of a Loss-ofCoolant Accident for Pressurized Water Reactors."

D. Regulatory Guide 1.7, "Control of Combustible Gas Concentrations in Containment Following a Loss-of-Coolant Accident." 
E. Regulatory Guide 1.11, "Instrument Lines Penetrating Primary Reactor containment."

F. Regulatory Guide 1.26, "Quality Group Classifications and Standards for water-, steam-, and Radioactive-WasteContaining Components of Nuclear Power Plants."

cation."

G. Regulatory Guide 1.29, "Seismic Design Classifi-

H. Regulatory Guide 1.52, "Design, Testing, and Maintenance Criteria for Post Accident Engineered-Safety-Feature Atmosphere Cleanup System Air Filtration and Adsorption Units of Light-Water-Cooled Nuclear Power Plants."

I. Regulatory Guide 1.63, "Electric Penetration Assemblies in Containment Structures for Nuclear Power Plants."

J. Regulatory Guide 1.82, "Water Sources for Long Term Recirculation Cooling Following a Loss of Coolant Accident."

K. Regulatory Guide 1.9.7, "Instrumentation for Light-Water-Cooled Nuclear Power Plants to Assess Plant and Environs Conditions During and Following an Accident."

L. Regulatory Guide 1.141, "Containment Isolation Provisions for Fluid Systems."

M. Regulatory Guide 1:145, "Atmospheric Dispersion Models for Potential Accident Consequence Assessments at Nuclear Power Plants."

N. SRP 6.2.1.5, Branch Technical Position CSB 6-1, "Minimum Containment Pressure Model for PWR ECCS Performance Evaluation."

0. SRP 6.2.3, Branch Technical Position CSB 6-3, "Determination of Bypass Leakage Paths in Dual Containment Plants."

P. SRP 6.2.4, Branch Technical Position CSB 6-4, "Containment Purging During Normal Plant Operations."

Q. SRP 6.2.5, Appendix A, "Description of COGAP (Combustible Gas Analyzer Program.)"

R. SRP 9.2.5, Branch Technical Position ASB 9-2, "Residual Decay Energy for Light Water Reactors for Long-Term Cooling." 


\subsubsection{Codes and standards}

A. ANSI/ASME N509-1980, "Nuclear Power Plant Air cleaning Units and Components." (This standard was revised and issued as ANSI/ASME N509-1989, "Nuclear Power Plant Air cleaning Units and Components.")

ing systems."

B. ANSI/ASME 510-1980, "Testing of Nuclear Air clean-

C. ASME Boiler and Pressure Vessel Code.

1. Section III, "Rules for construction of Nuclear Power Plant Components," Division 1 .

D. ANSI/IEEE 317-1983 (R1988), "IEEE standard for Electric Penetration Assemblies in Containment structures for Nuclear Power Generating stations."

\subsubsection{Bupplemental Information}

1987 .

A. NUREG-0800, USNRC "Standard Review Plan," June

1. SRP 6.2.1, "Containment Functional Design."

2. SRP 6.2.1.2, "Subcompartment Analysis."

3. SRP 6.2.1.3, "Mass and Energy Release Analysis for Postulated Loss-of-Coolant Accidents."

4. SRP 6.2.1.4, "Mass and Energy Release Analysis for Postulated Secondary System Pipe Ruptures."

5. SRP 6.2.1.5, "Minimum Containment Pressure Analysis for Emergency Core Cooling System Performance Capability studies."

tems."

6. SRP 6.2.2, "Containment Heat Removal Sys-

Design."

7. SRP 6.2.3, "Secondary Containment Functional

8. SRP 6.2.4, "Containment Isolation System."

tainment."

9. SRP 6.2.5, "Combustible Gas control in con-

10. SRP 6.2.6, "Containment Leakage Testing." 
11. SRP 6.2.7, "Fracture Prevention of Containment Pressure Boundary."

B. NUREG-0897, Rev. 1, "Containment Emergency Sump Performance -Technical Findings Related to USI A-43," USNRC, October 1985.

C. NUREG-0588, "Interim Staff Position on Environmental Qualification of Safety-Related Electrical Equipment," USNRC, July 1981.

D. NUREG-0718, "Licensing Requirements for Pending Applications for Construction Permits and Manufacturing License," USNRC, March 1981.

E. NUREG-0609, "Asymmetric Blowdown Loads on PWR Primary Systems," USNRC, January 1981.

F. NUREG-0737, "Clarification of TMI Action Plan Requirements," USNRC, November 1980.

G. NUREG-0660, "NRC Action Plan Developed as a Result of the TMI-2 Accident," USNRC, Vol. 1, May 1980 and Vol. 1, Rev. 1, August, 1980.

H. NUREG-0694, "TMI-Related Requirements for New Operation Licenses," USNRC, June 1980.

I. NUREG-0578, "TMI-2 Lessons Learned Task Force status Report and Short-Term Recommendations," USNRC, July 1979.

J. IE Information Notice 85-71, "Containment Integrated Leak Rate Tests."

Ḱ. ERDA 76-21, "Nuclear Air cleaning Handbook," Oak Ridge National Laboratory, C.A. Burchsted, I.E. Kahn and A.B. Fuller, March 31, 1976.

L. "CONTEMPT-LT Users Manual," Interim Report I-21474-12.1, R.J. Wagner and L.L. West, Aerojet Nuclear Company, August 1973 .

M. "Maximum Flow Rate of a single component, Two-Phase Mixture," F.J. Moody, Jour. of Heat Transfer, Trans. Am. Soc. of Mechanical Engineers, Vol. 87, No. 1, February 1965. 


\subsection{EMERGENCY CORE COOLING BYSTEM}

\subsubsection{Code of Federal Regulations}

A. 10 CFR 50.46, "Acceptance Criteria for Emergency Core cooling systems for Light-Water-Cooled Nuclear Power Reactors."

B. 10 CFR 50.55a, "Codes and Standards."

C. 10 CFR 50, Appendix A, "General Design Criteria for Nuclear Power Plants."

Natural Phenomena."

1. GDC 2, "Design Bases for Protection Against

Basis."

2. GDC 4, "Environmental and Missile Design components."

3. GDC 5, "Sharing of structures, systems, and

4. GDC 17, "Electric Power systems."

Capability." 5. GDC 27, "Combined Reactivity Control system

6. GDC 35, "Emergency Core Cooling."

ing system."

7. GDC 36, "Inspection of Emergency Core cool-

system."

8. GDC 37, "Testing of Emergency core cooling

D. 10 CFR 50, Appendix K, "ECCS Evaluation Models."

6.3.2 USNRC Regulatory Guides, SRP Branch Technical Positions and Appendices

A. Regulatory Guide 1.1, "Net Position Suction Head for Emergency Core cooling and containment Heat Removal system Pumps."

B. Regulatory Guide 1.29, "Seismic Design Classification," Revision 1.

C. Regulatory Guide 1.47, "Bypassed and Inoperable Status Indication for Nuclear Power Plant Safety Systems." 
D. Regulatory Guide 1.52, "Design, Testing, and Maintenance Criteria for Post Accident Engineered-Safety-Feature Atmosphere Cleanup System Air Filtration and Adsorption Units of Light-Water-Cooled Nuclear Power Plants."

E. Regulatory Guide 1.68, "Initial Test Programs for water-cooled Nuclear Power Plants."

F. Regulatory Guide 1.79, "Preoperational Testing of Emergency Core Cooling Systems for Pressurized Water Reactors."

G. Regulatory Guide 1.82, "Water Sources for LongTerm Recirculation Cooling Following a Loss-of-Coolant Accident."

H. Regulatory Guide 1.157, "Best Estimate Calculations of Emergency Core Cooling system Performance."

I. SRP 6.3, Branch Technical Position RSB 6-1, "Piping From the RWST (or BWST) and Containment sump(s) to the Safety Injection Pumps."

\subsection{3 codes and standards}

A. ANSI/ASME N509-1980, "Nuclear Power Plant Air Cleaning Units and Components."

Cleaning Units."

B. ANSI/ASME N510-1980, "Testing of Nuclear Air

C. ASME Boiler and Pressure Vessel code, section XI, "Rules for Inservice Inspection of Nuclear Power Plant Components."

D. IEEE 279-1971, "Criteria for Protection Systems for Nuclear Power Generating Stations." (This standard was withdrawn June 14, 1984 and incorporated into IEEE 603-1980, "IEEE standard criteria for safety systems for Nuclear Power Generating stations.")

E. ANSI/IEEE 603-1980, "IEEE Standard Criteria for Safety systems for Nuclear Power Generating stations."

\subsubsection{Bupplemental Information}

1987 .

A. NUREG-0800, USNRC "Standard Review Plan," June

1. SRP 6.3, "Emergency Core cooling system."

B. NUREG-0897, Rev. 1, "Containment Emergency Sump Performance Technical Findings Related to Unresolved Safety Issue A-43," USNRC, October 1985.

$$
6-10
$$


C. NUREG-0718, "Licensing Requirements for Pending Applications for Construction Permits and Manufacturing License," USNRC, March 1981.

D. NUREG-0737, "Clarification of TMI Action Plan Requirements," USNRC, November 1980.

E. NUREG-0660, "NRC Action Plan Developed as a Result of the TMI-2 Accident," USNRC, Vol. 1, May 1980 and Vol. 1, Rev. 1 , August 1980.

F. NUREG-0694, "TMI-Related Requirements for New operation Licenses," USNRC, June 1980.

G. IE Bulletin 79-24, "Frozen Lines."

H. Information Notice 81-31, "Failure of Safety Injection Valves to Operate Against Differential Pressure."

I. ERDA 76-21, "Nuclear Air cleaning Handbook," Oak Ridge National Laboratory, C.A. Burchsted, I.E. Kahn and A.B. Fuller, March 31, 1976.

\subsection{CONTROL ROOM HABITABILITY SYSTEM}

6.4.1 Code of Federal Regulations

A. 10 CFR 50, Appendix A, "General Design Criteria for Nuclear Power Plants."

Bases."

1. GDC 4, "Environmental and Missiles Design Components."

2. GDC 5, "Sharing of structures, systems, and

3. GDC 19:, "Control Room."

6.4.2 USNRC Regulatory Guides, SRP Branch Technical Positions and Appendices

A. Regulatory Guide 1.52, "Design, Testing, and Maintenance Criteria for Post Accident Engineered-Safety-Feature Atmosphere Cleanup System Air Filtration and Adsorption Units of Light-Water-Cooled. Nuclear Power Plants."

B. Regulatory Guide 1.78, "Assumptions for Evaluating the Habitability of a Nuclear Power Plant Control Room During a Postulated Hazardous Chemical Release." 
C. Regulatory Guide 1.95, "Protection of Nuclear Power Plant Control Room Operators Against an Accidental Chlorine Release."

D. SRP 6.4, Appendix A, "Acceptance Criteria for Valve or Damper Repair Alternative."

\subsubsection{Codes and standards}

A. ANSI/ASME N509-1980, "Nuclear Power Plant Air cleaning Units and Components." (This standard was revised and issued as ANSI/ASME N509-1989, "Nuclear Power Plant Air Cleaning Units and Components."

cleaning Units."

B. ANSI/ASME N510-1980, "Testing of Nuclear Air

\subsubsection{Supplemental Information}

June 1987 .

A. NUREG-0800, USNRC "Standard Review Plan," 1. SRP 6.4, "Control Room Habitability System."

B. NUREG-0737, "Clarification of TMI Action Plan Requirements," Item III.D.3.4, USNRC, November 1980 .

Hazards."

c. IE circular 80-03, "Protection From Toxic Gas

D. IE Information Notice 86-76, "Problems Noted in Control Room Emergency Ventilation Systems."

E. ERDA 76-21, "Nuclear Air cleaning Handbook," Oak Ridge National Laboratory, C.A. Burchsted, I.E. Kahn and A.B. Fuller, March 31, 1976.

F. "Nuclear Power Plant Control Room Ventilation system Design for Meeting General Design Criterion 19," K.G. Murphy and K.M Campe, 13th AEC Air Cleaning Conference, August 1974.

G. TID-25951, "Reactor shielding for Nuclear Engineers," N.M. Schaeffer, USAEC, 1973.

H. "Engineering Compendium on Radiation Shielding," R.G. Jaeger, et al., eds., Vol. 1, "Shielding Fundamentals and Methods," Springer-Verlag, 1968. 


\subsection{ENGINEERED BAFETY FEATURE (ESF) ATMOSPHERE CLEANUP BY8TEM}

This section identifies criteria for the design of ESF systems for fission product removal from post accident atmospheres by filtration, adsorption, and spray systems, and includes structures to contain these atmospheres.

\subsubsection{Code of Federal Regulations}

A. 10 CFR 50, Appendix A, "General Design Criteria for Nuclear Power Plants."

1. GDC 19, "Control Room."

2. GDC 41, "Containment Atmosphere Cleanup."

3. GDC 42, "Inspection of Containment Atmosphere cleanup systems."

4. GDC 43, "Testing of Containment Atmosphere cleanup systems."

5. GDC 61, "Fuel storage and Handling and Radioactivity Control."

6. GDC 64, "Monitoring Radioactivity Releases."

B. 10 CFR 100.11, "Determination of Exclusion Area, Low Population Zone, and Population Center Distance."

\subsubsection{USNRC Regulatory Guides, SRP Branch Technical Positions and Appendices}

The method of calculating $x / Q$ values in regulatory guides $1.3,1.4$, and 1.25 is superseded by the method presented in Regulatory Guide 1.145, "Atmospheric Dispersion Models for Potential Accident Consequence Assessments at Nuclear Power Plants."

A. Regulatory Guide 1.3, "Assumptions Used for Evaluating the Potential Radiological Consequences of a Loss-ofCoolant Accident for Boiling Water Reactors."

B. Regulatory Guide 1.4," "Assumptions Used for Evaluating the Potential Radiological Consequences of a Loss-ofCoolant Accident for Pressurized Water Reactors." .

c. Regulatory Guide 1.7, "Control of Combustible Gas Concentrations in Containment Following a Loss-of-Coolant Accident." 
D. Regulatory Guide 1.25, "Assumptions Used for Evaluating the Potential Radiological Consequences of a Fuel Handling Accident in the Fuel Handling and storage Facility for Boiling and Pressurized water Reactors."

E. Regulatory Guide 1.52, "Design, Testing, and Maintenance Criteria for Post Accident Engineering-Safety-Feature Atmosphere cleanup System Air Filtration and Adsorption Units of Light-Water-Cooled Nuclear Power Plants."

F. Regulatory Guide 1.145, "Atmospheric Dispersion Models for Potential Accident Consequence Assessments at Nuclear Power Plants."

\subsubsection{Codes and standards}

A. ANSI/ANS 56.5-1979 (R1987), "PWR and BWR Containment Spray System Design Criteria."

B. ANSI/ASME N509-1980, "Nuclear Power Plant Air cleaning Units and Components." (This standard was revised and issued as ANSI/ASME N509-1989, "Nuclear Power Plant Air Cleaning Units and Equipment.")

cleaning systems."

C. ANSI/ASME N510-1980, "Testing of Nuclear Air

\subsection{4 supplemental Information}

June 1987 .

A. NUREG-0800, USNRC "Standard Review Plan,"

1. SRP 6.5.1, "ESF Atmosphere Cleanup Systems."

2. SRP 6.5.2, "Containment Spray as a Fission Product cleanup system."

3. SRP 6.5.3, "Fission Product Control Systems and structures."

B. "Research on Removal of Iodine by containment sprays Containing Trace Levels of Hydrazine," D.L. Reid, B.M. Johnson, and A.K. Postma, Battelle Pacific Northwest Laboratories, June 1979.

C. ERDA 76-21, "Nuclear Air cleaning Handbook," Oak Ridge National Laboratory, C.A. Burchsted, I.E. Kahn, and A.B. Fuller, March 31, 1976. 
6.6 INGERVICE INSPECTION OF CLASS 2 AND 3 COMPONENTS

6.6.1 Code of Federal Regulations

A. $\quad 10$ CFR 50.55a, "Codes and Standards."

B. 10 CFR 50, Appendix A, "General Design Criteria For Nuclear Power Plants."

ing system."

1. GDC 36, "Inspection of Emergency Core Cool-

2. GDC 37, "Testing of Emergency core cooling

system."

3. GDC 39, "Inspection of containment Heat

Removal system."

system."

4. GDC 40, "Testing of Containment Heat Removal

5. GDC 42, "Inspection of Containment Atmosphere cleanup Systems."

6. GDC 43, "Testing of Containment Atmosphere cleanup systems."

tem."

7. GDC 45, "Inspection of cooling water sys-

8. GDC 46, "Testing of Cooling Water system."

6.6.2 USNRC Regulatory Guides, SRP Branch Technical Positions and Appendices

None.

6.6.3 Codes and standards

A. ASME Boiler and Pressure Vessel Code

1. Section III, "Rules for construction of Nuclear Power Plant Components," Division 1.

2. Section XI, "Rules for Inservice Inspection of Nuclear Power Plant Components." 


\subsection{4 supplemental Information}

A. NUREG-0800, USNRC "Standard Review Plan,"
June 1987.

3 Components." $1 . \quad$ SRP 6.6, "Inservice Inspection of class 2 and 
CHAPTER 7

INSTRUMENTATION AND CONTROLB

7.1 INTRODUCTION - IDENTIFICATION OF SAFETY-RELATED SYSTEMS AND SAFETY CRITERIA

This section in an SAR should list the safety-related instrument and control systems and describe the extent to which the recommendations in the identified regulatory guides are followed. Whenever alternative approaches are used, an acceptable level of safety must be demonstrated. Seismic and environmental qualification requirements for instrumentation and controls are identified in sections 3.10 and 3.11 .

7.1.1 Code of Federal Regulations Information."

A. 10 CFR 50.34, "Contents of Applications, Technical

B. 10 CFR 50.49, "Environmental Qualification of Electric Equipment Important to safety for Nuclear Power Plants."

c. $\quad 10$ CFR 50.55a, "Codes and standards."

D. 10 CFR 50, Appendix A, "General Design Criteria for Nuclear Power Plants."

1. GDC 1, "Quality standards and Records."

7.1.2 USNRC Regulatory Guides, SRP Branch Technical Positions and Appendices

A. Regulatory Guide 1.11, "Instrument Lines Penetrating Primary Reactor Containment."

B. Regulatory Guide '1.22, "Periodic Testing of Protection System Actuation Functions."

cation."

c. Regulatory Guide 1.29, "Seismic Design Classifi-

D. Regulatory Guide 1.30, "Quality Assurance Requirements for the Installation; Inspection, and Testing of Instrumentation and Electric Equipment."

E. Regulatory Guide 1:47, "Bypassed and Inoperable status Indication for Nuclear Power Plant Safety Systems." 
F. Regulatory Guide 1.53, "Application of the Single-Failure criterion to Nuclear Power Plant Protection Systems."

tective Actions."

G. Regulatory Guide 1.62, "Manual Initiation of Pro-

H. Regulatory Guide 1.63, "Electric Penetration Assemblies in Containment structures for Nuclear Power Plants."

I. Regulatory Guide 1.68, "Initial Test Programs for Water-Cooled Nuclear Power-Plants."

J. Regulatory Guide 1.68.3, "Preoperational Testing of Instrument and Control Air Systems."

K. Regulatory Guide 1.75, "Physical Independence of Electric systems."

L. Regulatory Guide 1.80, "Preoperational Testing of Instrument Air systems." (This guide was withdrawn in April 1982, revised, and designated Regulatory Guide 1.68.3, "Preoperational Testing of Instrument and Control Air systems.")

M. Regulatory Guide 1.97, "Instrumentation for Light-water-Cooled Nuclear Power Plants to Assess Plant and Environs Conditions During and Following an Accident."

N. Regulatory Guide 1.105, "Instrument Setpoints for Safety-Related systems."

0. Regulatory Guide 1.118, "Periodic Testing of Electric Power and Protection Systems."

Lines."

P. Regulatory Guide 1.151, "Instrument sensing

Q. Regulatory Guide 1.152, "Criteria for Programmable Digital Computer system software in safety-Related systems of Nuclear Power Plants."

R. Regulatory Guide 1.153, "Criteria for Power, Instrumentation, and control Portions of safety systems."

S. SRP 7.1, Appendix A, "Acceptance Criteria and Guidelines for Instrumentation and Control systems Important to Safety."

T. SRP 7.1, Appendix B, "Guidance for Evaluation of Conformance to IEEE sta. 279." 


\subsubsection{Codes and standards}

A. ANSI/ASME N45.2-1977, "Quality Assurance Program Requirements for Nuclear Power Plants." (This standard was withdrawn April 15, 1983 and incorporated into ANSI/ASME NQA-1-1986, "Quality Assurance Program Requirements for Nuclear Facilities.")

B. ANSI/IEEE 603-1980, "IEEE standard Criteria for Safety systems for Nuclear Power Generating stations."

C. ANSI/IEEE 741-1986, "IEEE standard Criteria for the Protection of Class 1E Power Systems and Equipment in Nuclear Power Generating stations."

D. ANSI/IEEE-ANS 4.3.2-1982, "Application Criteria for Programmable Digital Computer systems in safety systems of Nuclear Power Generating Stations."

E. ANSI/ISA S67.02-1980, "Nuclear Safety-Related Instrument sensing Line Piping and Tubing standards for Use in Nuclear Power Plants."

F. ASME Boiler and Pressure Vessel Code, Section XI, "Rules for Inservice Inspection of Nuclear Power Plant Components."

G. IEEE 279-1971, "Criteria for Protection Systems for Nuclear Power Generating stations." (This standard was withdrawn on June 14, 1984 and incorporated into ANSI/IEEE 603-1980, "IEEE Standard Criteria for Safety systems for Nuclear Power Generating stations.")

H. IEEE 317-1976 (R1988), "IEEE Standard for Electric Penetration Assemblies in Containment structures for Nuclear Power Generating stations." (This standard was revised and issued as ANSI/IEEE 317-1983, "IEEE Standard for Electric Penetration Assemblies in Containment structures for Nuclear Power Generating Stations.")

I. IEEE 334-1974(R1982), "IEEE standard for Type Tests of Continuous Duty Class 1E Motors for Nuclear Power Generating stations."

J. IEEE 338-1987, "IEEE standard criteria for the Periodic Surveillance Testing of Nuclear Power Generating station safety systems." 
K. IEEE 379-1977, "IEEE standard Application of the single-Failure criterion to Nuclear Power Generating station Class 1E systems." (This standard was revised and issued as ANSI/IEEE 379-1988, "IEEE standard Application of the SingleFailure Criterion to Nuclear Power Generating station Class $1 \mathrm{E}$ systems.")

L. IEEE 384-1977, "IEEE standard Criteria for Independence of Class 1E Equipment and circuits." (This standard was revised and issued as ANSI/IEEE 384-1981, "IEEE standard Criteria for Independence of Class $1 E$ Equipment and circuits.")

M. ISA S67.04-1982, "Setpoints for Nuclear SafetyRelated Instrumentation Used in Nuclear Power Plants."

7.1.4 supplemental Information

1987.

A. NUREG-0800, USNRC "Standard Review Plan," June Introduction."

1. SRP 7.1, "Instrumentation and Controls -

2. SRP 7.1, Table 7-1, "Acceptance Criteria and Guidelines for Instrumentation and Control systems Important to safety."

3. SRP 7.1, Table 7-2, "TMI Action Plan Requirements for Instrumentation and Control systems Important to safety."

7.2 REACTOR TRIP SYSTEM

7.2.1 Code of Federal Regulations Information."

A. 10 CFR 50.34, "Contents of Applications, Technical

B. 10 CFR 50.55a, "Codes and Standards."

C. 10 CFR 50, Appendix A, "General Design Criteria for Nuclear Power Plants."

Natural Phenomena."

1. GDC 2, "Design Bases for Protection Against Bases."

2. GDC 4, "Environmental and Missile Design

3. GDC 13, "Instrumentation and Control." 
4. GDC 19, "Control Room."

5. GDC 20, "Protection System Functions."

6. GDC 21, "Protection systems Reliability and

systems."

7. GDC 22, "Protection System Independence."

8. GDC 23, "Protection System Failure Modes."

9. GDC 24, "Separation of Protection and control

10. GDC 25, "Protection system Requirements for Reactivity Control Malfunctions."

tional Occurrences."

11. GDC 29, "Protection Against Anticipated Opera-

7.2.2 UshrC Regulatory Guides, SRP Branch Technical Positions and Appendices

A. Regulatory Guide 1.22, "Periodic Testing of Protection System Actuation Functions."

B. Regulatory Guide 1.47, "Bypassed and Inoperable status Indication for Nuclear Power Plant Safety Systems."

C. Regulatory Guide 1.53, "Application of the single-Failure Criterion to Nuclear Power Plant protection systems."

tection Actions."

D. Regulatory Guide 1.62, "Manual Initiation of Pro-

E. Regulatory Guide 1.75, "Physical: Independence of Electric Systems."

F. Regulatory Guide 1.105, "Instrument setpoints for Safety-Related systems.".

G. Regulatory Guide 1.118, "Periodic Testing of Electric Power and Protection Systems."

H. Regulatory Guide 1.153, "Criteria for Power, Instrumentation, and Control Portions of Safety Systems."

I. SRP Appendix 7-A, Branch Technical Position ICSB 12, "Protection system Trip Point Changes for operation with Reactor Coolant Pumps Out of Service." 
J. SRP Appendix 7-A, Branch Technical Position ICSB 14, "Spurious Withdrawals of single Control Rods in Pressurized water Reactors."

K. SRP Appendix 7-A, Branch Technical Position ICSB 21, "Guidance for Application of Regulatory Guide 1.47."

L. SRP Appendix 7-A, Branch Technical Position ICSB 22, "Guidance for Application of Regulatory Guide 1.22."

M. SRP Appendix 7-A, Branch Technical Position ICSB 26, "Requirements for Reactor Protection System Anticipatory Trips."

N. SRP 7.1, Appendix A, "Acceptance Criteria and Guidelines for Instrumentation and Control systems Important to Safety."

O. SRP 7.1, Appendix B, "Guidance for Evaluation of Conformance to IEEE std. 279."

\subsubsection{Codes and standards}

A. ANSI/IEEE 603-1980, "IEEE Standard Criteria for Safety Systems for Nuclear Power Generating stations."

B. IEEE 279-1971, "Criteria for protection systems for Nuclear Power Generating Stations." (This standard was withdrawn on June 14, 1984 and incorporated into ANSI/IEEE 603-1980, "IEEE standard Criteria for Safety Systems for Nuclear Power Generating stations.")

C. IEEE 338-1987, "IEEE standard Criteria for the Periodic Surveillance Testing of Nuclear Power Generating station safety systems."

D. IEEE 379-1977, "IEEE standard Application of the Single-Failure Criterion to Nuclear Power Generating station class 1E systems." (This standard was revised and issued as ANSI/IEEE 379-1988, "IEEE Standard Application of the SingleFailure Criterion to Nuclear Power Generating station Class $1 \mathrm{E}$ systems.")

E. IEEE 384-1977, "IEEE Standard Criteria for Independence of Class 1E Equipment and Circuits." (This standard was revised and issued as ANSI/IEEE 384-1981, "IEEE standard Criteria for Independence of Class $1 \mathrm{E}$ Equipment and circuits.")

F. ISA S67.04-1982, "Setpoints for Nuclear SafetyRelated Instrumentation Used in Nuclear Power Plants." 


\subsubsection{Bupplemental Information}

1987.

A. NUREG-0800, USNRC "Standard Review Plan," June

1. SRP 7.2, "Reactor Trip System."

B. NUREG-0718, "Licensing Requirements for Pending Applications for Construction Permits and Manufacturing License," USNRC, March 1981

C. NUREG-0737, "Clarification of TMI Action Plan Requirements," USNRC, November 1980.

D. NUREG-0694, "TMI-Related Requirements for New operation Licenses," USNRC, June 1980.

\subsection{ENGINEERED SAFETY FEATURE SYSTEMS}

\subsubsection{Code of Federal Regulations}

Information."

A. 10 CFR 50.34, "Contents of Applications, Technical

B. $\quad 10$ CFR 50.55a, "Codes and Standards."

C. 10 CFR 50, Appendix A, "General Design Criteria for Nuclear Power Plants."

Natural Phenomena."

1. GDC 2, "Design Bases for Protection Against Bases."

2. GDC 4, "Environmental and Missile Design

3. GDC 13, "Instrumentation and Control."

4. GDC 19, "Control Room."

5. GDC 20, "Protection. System Functions."

Testability."

6. GDC 21, "Protection Systems Reliability and

7. GDC 22, "Protection System Independence."

8. GDC 23, "Protection System Failure Modes."

systems."

9. GDC 24, "Separation of Protection and Control 
10. GDC 29, "Protection Against Anticipated Operational Occurrences."

11. GDC 34, "Residual Heat Removal."

12. GDC 35, "Emergrency Core Cooling."

13. GDC 38, "Containment Heat Removal."

14. GDC 41, "Containment Atmosphere Cleanup."

7.3.2 USNRC Regulatory Guides, SRP Branch Technical positions and Appendices

A. Regulatory Guide 1.22, "Periodic Testing of Protection System Actuation Functions."

B. Regulatory Guide 1.47, "Bypassed and Inoperable status Indication for Nuclear Power Plant Safety Systems."

C. Regulatory Guide 1.53, "Application of the single-Failure Criterion to Nuclear Power Plant Protection systems."

tection Actions."

D. Regulatory Guide 1.62, "Manual Initiation of Pro-

E. Regulatory Guide 1.75, "Physical Independence of Electric Systems."

F. Regulatory Guide 1.105, "Instrument setpoints for Safety-Related systems."

G. Regulatory Guide 1.118, "Periodic Testing of Electric Power and Protection Systems."

H. Regulatory Guide 1.153, "Criteria for Power, Instrumentation, and Control Portions of Safety Systems."

I. SRP Appendix 7-A, Branch Technical Position ICSB 12, "Protection System Trip Point Changes for Operation with Reactor Coolant Pumps out of Service."

J. SRP Appendix 7-A, Branch Technical Position ICSB 13, "Design Criteria for Auxiliary Feedwater Systems."

K. SRP Appendix 7-A, Branch Technical Position ICSB 20, "Design of Instrumentation and Controls Provided to Accomplish Changeover from Injection to Recirculation Mode." 
L. SRP Appendix 7-A, Branch Technical Position ICSB 21, "Guidance for Application of Regulatory Guide 1.47."

M. SRP Appendix 7-A, Branch Technical Position ICSB 22, "Guidance for Application of Regulatory Guide 1.22."

N. SRP 7.1, Appendix A, "Acceptance Criteria and Guidelines for Instrumentation and control systems Important to Safety."

O. SRP 7.1, Appendix B, "Guidance for Evaluation of Conformance to IEEE std. 279."

\subsubsection{Codes and standards}

A. ANSI/IEEE 603-1980, "IEEE Standard Criteria for safety systems for Nuclear Power Generating stations."

B. IEEE 279-1971, "Criteria for Protection systems for Nuclear Power Generating stations." (This standard was withdrawn on June 14, 1984 and incorporated into ANSI/IEEE 603-1980, "IEEE Standard Criteria for Safety Systems for Nuclear Power Generating stations.")

C. IEEE 338-1987, "IEEE standard Criteria for the Periodic Surveillance Testing of Nuclear Power Generating station safety systems."

D. IEEE 379-1977, "IEEE Standard Application of the Single-Failure Criterion to Nuclear Power Generating station Class 1E systems." (This standard was revised and issued as ANSI/IEEE 379-1988, "IEEE Standard Application of the SingleFailure Criterion to Nuclear Power Generating station Class $1 \mathrm{E}$ systems.")

E. IEEE 384-1977,.: "IEEE standard Criteria for Independence of Class $1 \mathrm{E}$ Equipment and Circuits." (This standard was revised and issued as ANSI/IEEE 384-1981, "IEEE Standard Criteria for Independence of Class 1E Equipment and circuits.")

F. ISA S67.04-1982, "Setpoints for Nuclear SafetyRelated Instrumentation. Used in Nuclear Power Plants."

7.3.4 Supplemental Information

1987.

A. NUREG-0800, USNRC "Standard Review Plan," June

tems."

1. SRP 7.3, "Engineered Safety Features sys- 
B. NUREG-0718, "Licensing Requirements for Pending Applications for Construction Permits and Manufacturing License," USNRC, March 1981.

C. NUREG-0737, "Clarification of TMI Action Plan Requirements," USNRC, November 1980.

D. NUREG-0694, "TMI-Related Requirements for New Operation Licenses," USNRC, June 1980.

\subsection{SAFE SHUTDOWN BYSTEMB}

\subsubsection{Code of Federal Regulations} Information."

A. 10 CFR 50.34, "Contents of Applications, Technical

B. 10 CFR 50.55a, "Codes and standards."

C. 10 CFR 50, Appendix A, "General Design Criteria for Nuclear Power Plants."

Natural Phenomena."

1. GDC 2, "Design Bases for Protection Against Bases."

2. GDC 4, "Environmental and Missile Design

3. GDC 13, "Instrumentation and Control."

4. GDC 19, "Control Room."

5. GDC 34, "Residual Heat Removal."

6. GDC 35, "Emergency core cooling."

7. GDC 38, "Containment Heat Removal."

7.4.2 USNRC Regulatory Guides, SRP Branch Technical Positions and Appendices

A. Regulatory Guide 1.22, "Periodic Testing of Protection system Actuation Functions."

B. Regulatory Guide 1.47, "Bypassed and Inoperable Status Indication for Nuclear Power Plant Safety systems."

C. Regulatory Guide 1.53, "Application of the Single-Failure Criterion to Nuclear Power Plant Protection systems." 
tection Actions."

D. Regulatory Guide 1.62, "Manual Initiation of Pro-

E. Regulatory Guide 1.68, "Initial Test Programs for water Cooled Nuclear Power Plants."

F. Regulatory Guide 1.75, "Physical Independence of Electric Systems."

G. Regulatory Guide 1.105, "Instrument setpoints for Safety-Related systems."

H. Regulatory Guide 1.118, "Periodic Testing of Electric Power and Protection Systems."

I. Regulatory Guide 1.153, "Criteria for Power, Instrumentation, and Control Portions of Safety systems."

J. SRP Appendix 7-A, Branch Technical Position ICSB 21, "Guidance for Application of Regulatory Guide 1.47."

K. SRP Appendix 7-A, Branch Technical Position ICSB 22, "Guidance for Application of Regulatory, Guide 1.22."

L. SRP 7.1, Appendix A, "Acceptance Criteria and Guidelines for Instrumentation and control systems Important to Safety."

M. SRP 7.1, Appendix B, "Guidance for Evaluation of Conformance to IEEE Std. 279."

\subsubsection{Codes and standards}

A. ANSI/IEEE 603-1980, "IEEE Standard Criteria for Safety Systems for Nuclear Power Generating stations."

B. ASME Boiler and Pressure Vessel Code, Section XI, "Rules for Inservice Inspection of Nuclear Power Plant Components."

C. IEEE 279-1971, "Criteria for Protection Systems for Nuclear Power Generating Stations." (This standard was withdrawn on June 14, 1984 and incorporated into-ANSI/IEEE 603-1980, "IEEE Standard Criteria for Safety systems for Nuclear Power Generating Stations.")

D. IEEE 338-1987, "IEEE standard Criteria for the Periodic Surveillance Testing of Nuclear Power Generating station Safety Systems." 
E. IEEE 379-1977, "IEEE standard Application of the Single-Failure Criterion to Nuclear Power Generating station class 1E systems." (This standard was revised and issued as ANSI/IEEE 379-1988, "IEEE Standard Application of the singleFailure Criterion to Nuclear Power Generating station Class $1 \mathrm{E}$ systems.")

F. IEEE 384-1977, "IEEE Standard Criteria for Independence of Class 1E Equipment and Circuits." (This standard was revised and issued as ANSI/IEEE 384-1981, "IEEE Standard Criteria for Independence of Class $1 \mathrm{E}$ Equipment and Circuits.")

G. ISA S67.04-1982, "Setpoints for Nuclear SafetyRelated Instrumentation Used in Nuclear Power Plants."

\subsection{4 supplemental Information}

1987

A. NUREG-0800, USNRC "standard Review Plan," June 1. SRP. 7.4, "Safe Shutdown Systems."

7.5 SAFETY-RELATED DISPLAY INSTRUMENTATION

7.5.1 Code of Federal Regulations

A. 10 CFR 50.55a, "Codes and Standards."

B. 10 CFR 50, Appendix A, "General Design Criteria for Nuclear Power Plants."

Natural Phenomena."

1. GDC 2, "Design Bases for Protection Against

Bases."

2. GDC 4, "Environmental and Missile Design

3. GDC 13, "Instrumentation and Control."

7.5.2 U8NRC Regulatory Guides, SRP Branch Technical Positions and Appendices

A. Regulatory Guide 1.22, "Periodic Testing of Protection system Actuation Functions."

B. Regulatory Guide 1.47, "Bypassed and Inoperable Status Indication for Nuclear Power Plant Safety Systems."

C. Regulatory Guide 1.53, "Application of the Single-Failure criterion to Nuclear Power Plant Protection systems." 
Electric Systems."

D. Regulatory Guide 1.75, "Physical Independence of

E. Regulatory Guide 1.97, "Instrumentation for Light water Cooled Nuclear Power Plants to Assess Plant and Environs Conditions During and Following an Accident."

F. Regulatory Guide 1.105, "Instrument setpoints for Safety-Related systems."

G. Regulatory Guide 1.118, "Periodic Testing of Electric Power and Protection Systems."

Lines."

H. Regulatory Guide 1.151, "Instrument sensing

I. Regulatory Guide 1.153, "Criteria for Power, Instrumentation, and Control Portions of safety systems."

J. SRP Appendix 7-A, Branch Technical Position ICSB 21, "Guidance for Application of Regulatory Guide 1.47."

K. SRP Appendix 7-A, Branch Technical Position ICSB 22, "Guidance for Application of Regulatory Guide 1.22."

L. SRP 7.1, Appendix A, "Acceptance Criteria and Guidelines for Instrumentation and Control Systems Important to Safety."

M. SRP 7.1, Appendix B, "Guidance for Evaluation of Conformance to IEEE std. 279."

\subsubsection{Codes and standards}

A. ANSI/ANS 4.5-1980(R1986), "Criteria for Accident Monitoring Functions in Light-Water-Cooled Reactors."

B. ANSI/IEEE 603-1980, "IEEE Standard Criteria for Safety Systems for Nuclear Power Generating Stations."

c. ANSI/ISA S67.02-1980, "Nuclear Safety Related Instrument Sensing Line Piping and Tubing Standards for Use in Nuclear Power Plants."

D. IEEE 279-1971, "Criteria for Protection systems for Nuclear Power Generating: Stations." (This standard was withdrawn on June 14, 1984 and incorporated into IEEE 603-1980, "IEEE Standard Criteria for Safety Systems for Nuclear Power Generating Stations.") 
E. IEEE 338-1987, "IEEE standard Criteria for Periodic Surveillance Testing of Nuclear Power Generating station safety systems."

F. IEEE 379-1977, "IEEE Standard Application of the Single-Failure Criterion to Nuclear Power Generating station Class 1E systems." (This standard was revised and issued as ANSI/IEEE 379-1988, "IEEE standard Application of the SingleFailure Criterion to Nuclear Power Generating station Class $1 \mathrm{E}$ systems.")

G. IEEE 384-1977, "IEEE Standard Criteria for Independence of Class $1 \mathrm{E}$ Equipment and Circuits." (This standard was revised and issued as ANSI/IEEE 384-1981, "IEEE Standard Criteria for Independence of Class 1E Equipment and circuits.")

H. ISA S67.04-1982, "Setpoints for Nuclear SafetyRelated Instrumentation Used in Nuclear Power Plants."

\subsubsection{Supplemental Information}

1987 .

A. NUREG-0800, USNRC "Standard Review Plan," June

safety."

1. SRP 7.5, "Information systems Important to

B. NUREG-0718, "Licensing Requirements for Pending Applications for Construction Permits and Manufacturing License," USNRC, March 1981.

C. NUREG-0696, "Functional Criteria for Emergency Response Facilities," USNRC, February 1981.

D. NUREG-0737, "Clarification of TMI Action Plan Requirements," USNRC, November 1980.

E. NUREG-0660, "NRC Action Plan Developed as a Result of the TMI-2 Accident," Item II:F.3, USNRC, Vol. 1, May 1980 and Vol. 1, Rev. 1, August 1980.

F. NUREG-0694, "TMI Related Requirements for New Operation Licenses," USNRC, June 1980.

7.6 ALL OTHER INSTRUMENTATION SYSTEMS REQUIRED FOR SAFETY

7.6.1 Code of Federal Regulations

Information."

A. 10 CFR 50.34, "Contents of Applications, Technical 
B. 10 CFR 50.55a, "Codes and standards."

C. 10 CFR 50, Appendix A, "General Design Criteria for Nuclear Power Plants." Natural Phenomena." GDC 2, "Design Bases for Protection Against Bases."

2. GDC 4, "Environmental and Missile Design

3. GDC 10, "Reactor Design."

4. GDC 13, "Instrumentation and control."

5. GDC 15, "Reactor Coolant System Design."

6. GDC 16, "Containment Design."

7. GDC 19, "Control Room."

8. GDC 28, "Reactivity Limits."

9. GDC 33, "Reactor Coolant Makeup."

10. GDC 34, "Residual Heat Removal."

11. GDC 35, "Emergency core cooling."

12. GDC 38, "Containment Heat Removal."

13. GDC 41, "Containment Atmosphere Cleanup."

14. GDC 44, "Cooling Water."

\subsubsection{USNRC Regulatory Guides, SRP Branch Technical Positions and Appendices}

A. Regulatory Guide 1.22, "Periodic Testing of Protection System Actuation Functions."

B. Regulatory Guide 1.47, "Bypassed and Inoperable Status Indication for Nuclear Power Plant Safety Systems."

C. Regulatory Guide 1.53, "Application of the Single-Failure Criterion to Nuclear Power Plant Protection systems."

tection Actions."

D. Regulatory Guide '1.62, "Manual Initiation of Pro- 
E. Regulatory Guide 1.75, "Physical Independence of Electric Systems."

F. Regulatory Guide 1.105, "Instrument setpoints for Safety-Related systems."

G. Regulatory Guide 1.118, "Periodic Testing of Electric Power and Protection systems."

H. Regulatory Guide 1.153, "Criteria for Power, Instrumentation, and Control Portions of Safety systems."

I. SRP Appendix 7-A, Branch Technical Position ICSB 3, "Isolation of Low Pressure systems from the High Pressure Reactor Coolant System."

J. SRP Appendix 7-A, Branch Technical Position ICSB 4, "Requirements on Motor-Operated Valves in the ECCS Accumulator Lines."

K. SRP Appendix 7-A, Branch Technical Position ICSB 21, "Guidance for Application of Regulatory Guide 1.47."

L. SRP Appendix 7-A, Branch Technical Position ICSB 22, "Guidance for Application of Regulatory Guide 1.22."

M. SRP 7.1, Appendix A, "Acceptance Criteria and Guidelines for Instrumentation and Control systems Important to Safety."

N. SRP 7.1, Appendix B, "Guidance for Evaluation of Conformance to IEEE std. 279."

\subsubsection{Codes and standards}

A. ANSI/IEEE 603-1980, "IEEE Standard criteria for Safety Systems for Nuclear Power Generating Stations."

B. IEEE 279-1971, "Criteria for Protection Systems for Nuclear Power Generating stations." (This standard was withdrawn on June 14, 1984 and incorporated into ANSI/IEEE 603-1980, "IEEE Standard Criteria for Safety systems for Nuclear Power Generating stations.")

C. IEEE 338-1987, "IEEE standard Criteria for the Periodic Surveillance Testing of Nuclear Power Generating Station Safety systems." 
D. IEEE 379-1977, "IEEE Standard Application of the single-Failure Criterion to Nuclear Power Generating station Class 1E systems." (This standard was revised and issued as ANSI/IEEE 379-1988, "IEEE Standard Application of the SingleFailure Criterion to Nuclear Power Generating station Class $1 E$ systems.")

E. IEEE 384-1977, "IEEE standard Criteria for Independence of class $1 \mathrm{E}$ Equipment and Circuits." (This standard was revised and issued as ANSI/IEEE 384-1981, "IEEE standard Criteria for Independence of Class $1 \mathrm{E}$ Equipment and circuits.")

-F. ISA S67.04-1982, "Setpoints for Nuclear SafetyRelated Instrumentation Used in Nuclear Power Plants."

7.6.4 supplemental Information

1987.

A. NUREG-0800, USNRC "Standard Review Plan," June

safety."

1. SRP 7.6," Interlock systems Important to

B. NUREG-0737, "Clarification of TMI Action Plans," USNRC, November 1980 .

7.7 CONTROL BYSTEMS NOT REQUIRED FOR BAFETY

7.7.1 Code of Federal Regulations

A. 10 CFR 50, Appendix A, "General Design Criteria for Nuclear Power Plants."

1. GDC 13, "Instrumentation and Control."

2. GDC 19, "Control Room."

7.7.2 USNRC Regulatory Guides, SRP Branch Technical Positions and Appendices

A. Regulatory Guide 1.151, "Instrument sensing Lines."

B. SRP Appendix 7-A, Branch Technical Position ICSB 14, "Spurious Withdrawals of Single Control Rods in Pressurized water Reactors.".

C. SRP 7.1, Appendix A, "Acceptance Criteria and Guidelines for Instrumentation and Control systems Important to safety." 


\subsubsection{Codes and standards}

A. ANSI/ISA S67.02-1980, "Nuclear Safety-Related Instrument sensing Line Piping and Tubing standards for Use in Nuclear Power Plants."

\subsection{4 supplemental Information}

1987.

A. NUREG-0800, USNRC "Standard Review Plan," June 1. SRP 7.7, "Control Systems."

o

B. NUREG-0737, "Clarification of TMI Action Plan Requirements," USNRC, November 1980.

C. NUREG-0718, "Licensing Requirements for Pending Applications for Construction Permits and Manufacturing License," USNRC, March 1981.

D. NUREG-0694, "TMI-Related Requirements for New Operating Licenses," USNRC, June 1980. 
CHAPTER 8

ELECTRIC POWER

\subsection{INTRODUCTION}

This section in an SAR should include a brief description of the offsite and onsite electric power systems. In addition, it should describe the extent to which the recommendations in the regulatory guides listed in 8.2 offsite Power system and 8.3 Onsite Power System are followed. Whenever alternative approaches are used, an acceptable level of safety must be demonstrated. Seismic and environmental qualification requirements for electric power systems are identified in sections 3.10 and 3.11 .

\subsection{OFFSITE POWER SYSTEM}

8.2.1 Code of Federal Regulations

Power."

A. $\quad 10$ CFR 50.55a; "Codes and standards."

B. 10 CFR 50.63, "Loss of All Alternating Current

C. 10 CFR 50, Appendix A, General Design Criteria for Nuclear Power Plants."

Components." 1 . GDC 5, "Sharing of structures, systems, and

2. GDC 17, "Electric Power Systems."

Power systems." 3. GDC 18, "Inspection and Testing of Electrical

8.2.2 USNRC Regulatory Guides, SRP Branch Technical Positions and Appendices

A. Regulatory Guide 1.32 , "Criteria for SafetyRelated Electric Power systems for Nuclear Power Generating Plants."

B. Regulatory Guide 1.47, "Bypassed and Inoperable status Indication for Nuclear Power Plant Safety Systems."

c. Regulatory Guide 1.81, "Shared Emergency and Shutdown Electric systems for Multi-Unit Nuclear Power Plants." 


\section{Regulatory Guide 1.155, "Station Blackout."}

E. SRP Appendix 8-A, Branch Technical Position ICSB, 11 (PSB), "Stability of Offsite Power Systems."

F. SRP Appendix 8-A, Branch Technical Position ICSB 21, "Guidance for Application of Regulatory Guide 1.47.

G. SRP 8.2, Appendix A, "Guidelines for Generator Circuit Breakers/Load Break Switches."

\subsubsection{Codes and standards}

A. ANSI/IEEE 603-1980, "IEEE Standard Criteria for Safety Systems for Nuclear Power Generating Stations."

B. ANSI/IEEE 765-1983, "IEEE Standard for Preferred Power Supply for Nuclear Power Generating stations."

C. IEEE 279-1971, "Criteria for Protection systems for Nuclear Power Generating stations." (This standard was withdrawn on June 14, 1984 and incorporated into ANSI/IEEE 603-1980, "IEEE Standard Criteria for Safety systems for Nuclear Power Generating stations.")

D. IEEE 308-1974, "IEEE Standard Criteria for Class $1 \mathrm{E}$ Power Systems for Nuclear Power Generating stations." (This standard was revised and issued as IEEE 308-1980, "IEEE standard Criteria for Class $1 \mathrm{E}$ Power systems for Nuclear Power Generating stations.")

\subsubsection{Supplemental Information}

1987.

A. NUREG-0800, USNRC "Standard Review Plan," June

\section{SRP 8.2, "Offsite Power System."}

B. IE Information Notice 86-15, "Loss of offsite Power Caused by Problems in Fibre Optics Systems."

$8 \cdot 3$

ONSITE POWER SYBTEMS

Criteria for both onsite ac and dc power systems are identified in this section.

8.3.1 Code of Federal Regulations

A. 10 CFR 50.49, "Environmental Qualification of Electric Equipment Important to safety for Nuclear Power Plants." 
B. 10 CFR 50.55a, "Codes and Standards."

Power."

C. 10 CFR 50.63, "Loss of All Alternating Current

D. 10 CFR 50, Appendix A, "General Design Criteria for Nuclear Power Plants."

Natural Phenomena."

1. GDC 2, "Design Bases for Protection Against

Bases."

2. GDC 4, "Environmental and Missile Design

Components."

3. GDC 5, "Sharing of structures, Systems, and

4. GDC 17, "Electric Power Systems."

5. GDC 18, "Inspection and Testing of Electrical

Power Systems."

6. GDC 44, "Cooling Water."
7. GDC 50, "Containment Design Basis."

8.3.2 USNRC Regulatory Guides, SRP Branch Technical Positions and Appendices

A. Regulatory Guide 1.6, "Independence Between Redundant standby (Onsite) Power Sources and Between Their Distribution systems."

B. Regulatory Guide 1.9, "Selection, Design, and Qualification of Diesel-Generator Units Used as Standby (Onsite) Electric Power Systems at Nuclear Power Plants."

C. Regulatory Guide 1.3.2, "Criteria for safetyRelated Electric Power Systems for Nuclear Power Plants."

D. Regulatory Guide 1.47, "Bypassed and Inoperable Status Indication for Nuclear Power Plant Safety Systems."

E. Regulatory Guide 1.53, "Application of the single-Failure Criterion to Nuclear Power Plant Protection Systems."

F. Regulatory Guide 16. "Electric Penetration Assemblies in Containment Structures for Nuclear Power Plants." 
G. Regulatory Guide 1.75, "Physical Independence of Electric Systems."

H. Regulatory Guide 1.81, "Shared Emergency and Shutdown Electric systems for Multi-Unit Nuclear Power Plants."

I. Regulatory Guide 1.106, "Thermal overload Protection for Electric Motors on Motor-Operated Valves."

J. Regulatory Guide 1.108, "Periodic Testing of Diesel Generator Units Used as onsite Electric Power systems at Nuclear Power Plants."

K. Regulatory Guide 1.118, "Periodic Testing of Electric Power and Protection Systems."

L. Regulatory Guide 1.128, "Installation Design and Installation of Large Lead storage Batteries for Nuclear Power plants."

M. Regulatory Guide 1.129, "Maintenance, Testing, and Replacement of Large Lead storage Batteries for Nuclear Power Plants."

N. Regulatory Guide 1.153, "Criteria for Power, Instrumentation, and Control Portions of safety systems."

0. Regulatory Guide 1.155, "Station Blackout."

P. SRP Appendix 8A, Branch Technical position ICSB 4, "Requirements on Motor-Operated Valves in the ECCS Accumulator Lines."

Q. SRP Appendix 8A, Branch Technical Position ICSB 8, (PSB), "Use of Diesel-Generator Sets for Peaking."

R. SRP Appendix 8A, Branch Technical Position ICSB 18, (PSB), "Application of the Single-Failure Criterion to Manually-Controlled Electrically-Operated Valves."

S. SRP Appendix 8A, Branch Technical Position ICSB 21, "Guidance for Application of Regulatory Guide 1.47.

T. SRP Appendix 8-A, Branch Technical Position PSB1, "Adequacy of Station Electric Distribution System Voltages."

U. SRP Appendix 8-A, Branch Technical Position PSB2, "Criteria for Alarms and Indications Associated with DieselGenerator Unit Bypassed and Inoperable Status." 


\subsubsection{Codes and standards}

A. ANSI/IEEE 603-1980, "IEEE Standard Criteria for Safety systems for Nuclear Power Generating stations."

B. ANSI/IEEE 765-1983, "IEEE standard for Preferred Power supply for Nuclear Power Generating stations."

C. IEEE 279-1971, "Criteria for protection systems for Nuclear Power Generating stations." (This standard was withdrawn on June 14, 1984 and incorporated into ANSI/IEEE 603-1980, "IEEE Standard Criteria for Safety systems for Nuclear Power Generating stations.")

D. IEEE 308-1974, "IEEE standard Criteria for Class IE Power Systems for Nuclear Power Generating stations." (This standard has been revised and issued as IEEE 308-1980, "IEEE Standard Criteria for Class $1 \mathrm{E}$ Power systems for Nuclear Power Generating stations.")

E. IEEE 317-1983, "IEEE standard for Electric Penetration Assemblies in Containment structures for Nuclear Power Generating stations."

F. IEEE 338-1987, "IEEE standard Criteria for the Periodic Surveillance Testing of Nuclear Power Generating station safety systems."

G. IEEE 379-1972, "IEEE Trial-Use Guide for the Application of the single-Failure Criterion to Nuclear Power Generating station class $1 \mathrm{E}$ systems." (This standard was revised and issued as IEEE 379-1988, "IEEE standard Application of the Single-Failure criterion to Nuclear Power Generating station class 1E systems.")

H. IEEE 384-1977, "IEEE Standard Criteria for Independence of Class 1E Equipment and Circuits." (This standard was revised and issued as ANSI/IEEE 384-1981, "IEEE Standard Criteria for Independence of Class 1E Equipment and circuits.")

I. IEEE 387-1977, "IEEE Standard Criteria for DieselGenerator Units Applied as standby Power supplies for Nuclear Power Generating stations." (This standard was revised and issued as ANSI/IEEE 387-1984, "IEEE standard Criteria for DieselGenerator Units Applied as Standby Power Supplies for Nuclear Power Generating stations.") 
J. IEEE 450-1975, "IEEE Recommended Practices for Maintenance, Testing, and Replacement of Large Lead Storage Batteries for Generating stations and Substations." (This standard was revised and issued as ANSI/IEEE 450-1987, "IEEE Recommended Practices for Maintenance, Testing, and Replacement of Large Lead storage Batteries for Generating stations and Substations.")

K. IEEE 484-1975, "IEEE Recommended Practice for Installation Design and Installation of Large Lead storage Batteries for Generating stations and Substations." (This standard was revised and issued as ANSI/IEEE 484-1987, "IEEE Recommended Practice for Installation Design and Installation of Large Lead storage Batteries for Generating stations and substations.")

L. IEEE 741-1986, "IEEE standard Criteria for the Protection of Class $1 \mathrm{E}$ Power systems and Equipment in Nuclear Power Generating stations."

\subsubsection{Bupplemental Information}

1987 .

A. NUREG-0800, USNRC "Standard Review Plan," June

$$
\begin{aligned}
& \text { 1. SRP 8.3.1, "A-C Power systems (Onsite)." } \\
& \text { 2. SRP 8.3.2, "D-C Power systems (Onsite)." }
\end{aligned}
$$

B. NUREG-0718, "Licensing Requirements for Pending Applications for Construction Permits and Manufacturing License," USNRC, March 1981.

c. NUREG-0737, "Clarifications of TMI Action Plan Requirements," USNRC, November 1980.

D. NUREG-1296, "Thermal Overload Protection for Electric Motors on Safety-Related Motor-Operated Valves-Generic Issue II.E.6.1."

E. NUREG/CR-0660, "Enhancement of Onsite Emergency Diesel Generators Reliability."

F. IE Information Notice 86-70, "Potential Failure of all Emergency Diesel Generators."

G. IE Information Notice 84-83, "Various Battery Problems."

H. IE Information Notice 81-05, "Degraded D-C System at Palisades." 


\section{CHAPTER 9}

\section{AUXILIARY BYSTEMS}

The criteria identified in this chapter are for auxiliary systems that provide support functions, such as fuel storage and handling, cooling, ventilation, effluent release control, and fire protection.

\subsection{FUEL STORAGE AND HANDLING}

Criteria for new fuel storage, spent fuel storage and cooling, refueling, and the fuel handling associated with these activities are identified in this section.

\subsubsection{Code of Federal Regulations}

A. $\quad 10$ CFR 20.1(c), "Purpose."

B. 10 CFR 50.55a, "Codes and Standards."

C. 10 CFR 50, Appendix A, "General Design Criteria for Nuclear Power Plants."

1. GDC 2, "Design Bases for Protection Against Bases."

2. GDC 4, "Environmental and Missile Design components." 3. GDC 5, "Sharing of structures, systems and tems."

4. GDC 44, "Cooling Water."

5. GDC 45, "Inspection of Cooling water sys6. GDC 46, "Testing of Cooling water systems."

7. GDC 61, "Fuel storage and Handling and Radioactivity Control."

8. GDC 62, "Prevention of Criticality in Fuel storage and Handling."

9. GDC 63, "Monitoring Fuel and Waste storage." 
9.1.2 USNRC Regulatory Guides, sRP Branch Technical Positions and Appendices

ity Design Basis."

A. Regulatory Guide 1.13, "Spent Fuel storage Facil-

B. Regulatory Guide 1.26, "Quality Group Classifications and standards for Water-, Steam-, and Radioactive-WasteContaining Components of Nuclear Power Plants."

cation."

C. Regulatory Guide 1.29, "Seismic Design Classifi-

D. Regulatory Guide 1.52, "Design, Testing, and Maintenance Criteria for Post Accident Engineered-Safety-Feature Atmosphere Cleanup System Air Filtration and Adsorption Units of Light-Water-Cooled Nuclear Power Plants."

E. Regulatory Guide 1.115, "Protection Against LowTrajectory Turbine Missiles."

F. Regulatory Guide 1.117, "Tornado Design Classification."

G. Regulatory Guide 8.8, "Information Relevant to Ensuring That Occupational Radiation Exposures at Nuclear Power stations will Be as Low as is Reasonably Achievable."

H. SRP 9.2.5, Branch Technical Position ASB 9-2, "Residual Decay Energy for Light-Water Reactors for Long-Term Cooling."

\subsubsection{Codes and standards}

A. ANSI N510-1975, "Testing of Nuclear Air cleaning systems." (This standard was revised and issued as ANSI/ASME N510-1980, "Testing of Nuclear Air Cleaning systems.")

B. ANSI/ANS 57.1-1980, "Design Requirements for Light Water Reactor Fuel Handling systems."

C. ANSI/ANS 57.2-1983, "Design Requirements for Light Water Reactor spent Fuel storage Facilities at Nuclear Power stations"

D. ANSI/ANS 57.3-1983, "Design Requirements for New Fuel storage Facilities at Light water Reactor Plants."

E. ANSI/ASME B31.1, "Power Piping." 
F. ANSI/ASME N509-1976, "Nuclear Power Plant Air cleaning Units and Components." (This standard was revised and issued as ANSI/ASME N509-1980, "Nuclear Power Plant Air Cleaning Units and Components.")

G. ASME Boiler and Pressure Vessel Code.

1. Section III, "Rules for construction of Nuclear Power Plant Components," Division 1 .

2. Section VIII, "Rules for construction of Pressure Vessels," Division 1 .

3. Section XI, "Rules for Inservice Inspection of Nuclear Power Plant Components."

\subsection{4 supplemental Information}

1987.

A. NUREG-0800, USNRC "Standard Review Plan," June

1. SRP 9.1.1, "New Fuel storage."

2. SRP 9.1.2, "Spent Fuel storage."

Cleanup system." SRP 9.1.3, "Spent Fuel Pool cooling and

4. SRP 9.1.4, "Light Load Handling system (Related to Refueling)."

Systems."

5. SRP 9.1.5, "Overhead Heavy Load Handling

B. NUREG-0612, "Control of Heavy Loads at Nuclear Power Plants," USNRC, July 1980.

C. NUREG-0554, "Single-Failure-Proof cranes for Nuclear Power Plants," USNRC, May 1979.

D. IE Bulletin 79-24, "Frozen Lines."

E. IE Information Notice 85-12, "Recent Fuel Handling Events." Events."

F. IE Information Notice 80-01, "Fuel Handling 
This section identifies criteria for the following systems: service water, reactor auxiliary cooling water, demineralized water, potable and sanitary water, ultimate heat sink, and condensate storage.

\subsubsection{Code of Federal Regulations}

A. 10 CFR 50.55a, "Codes and standards."

B. 10 CFR 50, Appendix A, "General Design Criteria for Nuclear Power Plants."

Natural Phenomena."

1. GDC 2, "Design Bases for Protection Against

Bases."

2. GDC 4, "Environmental and Missile Design components."

3. GDC 5, "Sharing of structures, Systems and

4. GDC 44, "Cooling Water."

tems."

5. GDC 45, "Inspection of cooling water sys-

6. GDC 46, "Testing of Cooling Water systems."

Materials to the Environment."

\subsubsection{USNRC Regulatory Guides, BRP Branch Technical Positions and Appendices}

A. Regulatory Guide 1.26, "Quality Group Classifications and standards for Water-steam-, and Radioactive wasteContaining Components of Nuclear Power Plants."

B. Regulatory Guide 1.27, "Ultimate Heat sink for Nuclear Power Plants."

cation."

C. Regulatory Guide 1.29, "Seismic Design Classifi-

D. Regulatory Guide 1.72, "Spray Pond Piping Made From Fiberglass Reinforced Thermosetting Resin."

E. SRP 9.2.5, Branch Technical Position ASB 9-2, "Residual Decay Energy for Light water Reactors for Long-Term cooling." 
F. SRP 3.6.1, Branch Technical Position ASB 3-1, "Protection Against Postulated Failures in Fluid Systems Outside Containment."

\subsubsection{Codes and standards}

A. ANSI/ASME B31.1, "Power Piping."

B. ANSI/IEEE 603-1980, "IEEE Standard Criteria for Safety systems for Nuclear Power Generating stations."

C. ASME Boiler and Pressure Vessel Code.

1. Section III, "Rules for construction of Nuclear Power Plant Components," Division 1.

2. Section VIII, "Rules for construction of Pressure Vessels," Division 1.

3. Section XI, "Rules for Inservice Inspection of Nuclear Power Plant Components."

D. IEEE 279-1971, "Criteria for Protection systems for Nuclear Power Generating stations." (This standard was withdrawn on June 14, 1984 and incorporated into ANSI/IEEE 603-1980, "IEEE standard Criteria for Safety systems for Nuclear Power Generating stations.")

\subsubsection{Supplemental Information}

1987 .

A. NUREG-0800, USNRC "standard Review Plan," June

systems."

1. SRP 9.2.1, "Station Service Water System."

2. SRP 9.2.2, "Reactor Auxiliary Cooling water

tem."

3. SRP 9.2.3, "Demineralized Water Makeup Systems."

4. SRP 9.2.4, "Potable and Sanitary Water Sys-

5. SRP 9.2.5, "Ultimate Heat sink."

6. SRP 9.2.6, "Condensate storage Facilities."

B. NUREG-0718, "Licensing Requirements for Pending Applications for Construction Permits and Manufacturing License," USNRC, March 1981. 
C. NUREG-0737, "Clarification of TMI Action Plan Requirements," USNRC, November 1980.

D. NUREG-0694, "TMI-Related Requirements for New Operation Licenses," USNRC, June 1980.

E. IE Bulletin 81-03, "Flow Blockage of Cooling water to Safety system Components by Corbicula. (Asiatic Clam) and Mytilus. (Mussel)."

F. IE Circular 80-14, "Radioactive Contamination of Plant Demineralized Water system and Resultant Internal contamination of Personnel."

G. IE Information Notice 86-96, "Heat Exchanger Fouling Can Cause Inadequate Operability of Service water Systems."

H. IE Information Notice 85-30, "Microbiologically Induced Corrosion of containment Service water system."

I. IE Information Notice 85-24, "Failures of Protective Coatings in Pipes and Heat Exchangers."

J. IE Information Notice 81-21, "Potential Loss of Direct Access to Ultimate Heat Sink."

\subsection{PROCESS AUXILIARIES}

The criteria identified in this section are for the following auxiliary systems: compressed air, process and postaccident sampling, equipment and floor drainage, and poison (neutron absorber) fluid systems.

9.3.1 Code of Federal Regulations

A. 10 CFR 20.1(c), "Purpose."

B. 10 CFR 50.55a, "Codes and Standards."

C. 10 CFR 50, Appendix A, "General Design Criteria for Nuclear Power Plants."

1. GDC 1, "Quality standards and Records."

2. GDC 2, "Design Bases for Protection Against

Natural Phenomena."

Bases."

3. GDC 4, "Environmental and Missile Design $9-6$ 
Components." 4. GDC 5, "Sharing of structures, systems and

5. GDC 13, "Instrumentation and Control."

6. GDC 14, "Reactor Coolant Pressure Boundary."

7. GDC 26, "Reactivity control system Redundancy and Capability."

8. GDC 27, "Combined Reactivity Control systems

9. GDC 29, "Protection Against Anticipated operational occurrences."

10. GDC 33, "Reactor Coolant Makeup."

11. GDC 35, "Emergency Core cooling."

12. GDC 41, "Containment Atmosphere Cleanup."

13. GDC 60, "Control of Releases of Radioactive Materials to the Environment."

14. GDC 61, "Fuel storage and Handing and Radioactivity Control."

15. GDC 63, "Monitoring Fuel and Waste storage."

16. GDC 64, "Monitoring Radioactivity Releases."

9.3.2 USNRC Regulatory Guides, SRP Branch Technical Positions and Appendices

A. Regulatory Guide 1.21, "Measuring, Evaluating, and Reporting Radioactivity in Solid wastes and Releases of Radioactive Materials in Liquid and Gaseous Effluents from LightWater-Cooled Nuclear Power Plants."

B. Regulatory Guide 1.26, "Quality Group Classifications and standards for Water-, steam-, and Radioactive-WasteContaining Components of Nuclear Power Plants."

cation."

C. Regulatory : Guide' 1.29," "Seismic Design Classifi-

D. Regulatory Guide 1.56, "Maintenance of Water Purity in Boiling water Reactors." 
E. Regulatory Guide 1.68.3, "Preoperational Testing of Instrument and Control Air systems."

F. Regulatory Guide 1.97, "Instrumentation for Light-Water-Cooled Nuclear Power Plants to Assess Plant and Environs Conditions During and Following an Accident."

G. Regulatory Guide 8.8, "Information Relevant to Ensuring That Occupational Radiation Exposures at Nuclear Power Stations will Be as Low as is Reasonably Achievable."

\subsection{3 codes and standards}

A. ANSI N13.1-1969(R1982), "Guide to Sampling Airborne Radioactive Materials in Nuclear Facilities." ment Air."

B. ANSI/ISA-S7.3-1981, "Quality standard for Instru-

c. ANSI/ASME B31.1, "Power Piping."

D. ASME Boiler and Pressure Vessel Code

1. Section III, "Rules for construction of Nuclear Power Plant Components," Division 1.

sure Vessels," Division 1.

2. Section VIII, "Rules for Construction of Pres-

3. Section XI, "Rules for Inservice Inspection of Nuclear Power Plant Components."

9.3.4 supplemental Information

198.7.

A. NUREG-0800, USNRC "Standard Review Plan," June

1. SRP 9.3.1, "Compressed Air."

2. SRP 9.3.2, "Process and Post Accident Samp-

ling systems."

System."

3. SRP 9.3.3, "Equipment and Floor Drainage

4. SRP 9.3.4, "Chemical and Volume Control system (PWR) (Including Boron Recovery system)."

(BWR) . "

5. SRP 9.3.5, "Standby Liquid Control system 
B. NUREG-0718, "Licensing Requirements for Pending Applications for Construction Permits and Manufacturing License," USNRC, March 1981.

C. NUREG-0737, "Clarifications of TMI Action Plan Requirements," USNRC, November 1980.

D. IE Bulletin 80-05, "Vacuum Condition Resulting in Damage to Chemical Volume Control System (CVCS) Holdup Tanks."

E. IE Information Notice 81-38, "Potential significant Equipment Failures Resulting from Contamination of Airoperated systems."

F. IE Information Notice 79-08, "Interconnection of Contaminated Systems with Service Air Systems Used as the Source of Breathing Air."

\subsection{AIR CONDITIONING, HEATING, COOLING, AND VENTILATION SYSTEMS}

The criteria identified in this section are for the following ventilation systems: control room, spent fuel storage pool area, auxiliary and radwaste areas, turbine building, and engineered safety feature ventilation.

\subsubsection{Code of Federal Regulations}

A. 10 CFR 50.34a, "Design Objectives for Equipment to Control Releases of Radioactive Material in Effluents - Nuclear Power Reactors."

B. 10 CFR 50.36a, "Technical specifications on Effluents from Nuclear Power Reactors."

C. 10 CFR 50, Appendix A, "General Design Criteria for Nuclear Power Plants."

Natural Phenomena." GDC 2, "Design Bases for Protection Against Bases."

2. GDC 4, "Environmental and Missile Desiyn 3. GDC 5, "Sharing of structures, Systems and Components."

4. GDC 17,.. "Electric Power Systems."

5. GDC 19, "Control Room." 
6. GDC 60, "Control of Releases of Radioactive Materials to the Environment."

7. GDC 61, "Fuel storage and Handling and Radioactivity Control."

9.4.2 UsMrC Regulatory Guides, BRP Branch Technical positions and Appendices A.
ity Degulatory Guide 1.13, "Spent Fuel Storage FacilA. Regulatory Guide 1.13, "Spent Fuel storage Facil-
ity Design Basis." cation."

B. Regulatory Guide 1.29, "Seismic Design Classifi-

c. Regulatory Guide 1.52, "Design, Testing, and Maintenance Criteria for Post Accident Engineered-Safety-Feature Atmosphere cleanup System Air. Filtration and Adsorption Units of Light-Water-Cooled Nuclear Power Plants."

D. Regulatory Guide 1.78, "Assumptions for Evaluating the Habitability of a Nuclear Power Plant Control Room During a Postulated Hazardous Chemical Release."

E. Regulatory Guide 1.95, "Protection of Nuclear Power Plant Control Room operators Against an Accidental Chlorine Release."

F. Regulatory Guide 1.140, "Design, Testing and Maintenance Criteria for Normal Ventilation Exhaust system Air Filtration and Adsorption Units of Light-Water-Cooled Nuclear Power Plants."

\subsubsection{Codes and standards}

A. ANSI N510-1975, "Testing of Nuclear Air Cleaning systems." (This standard was revised and issued as ANSI/ASME N510-1980, "Testing of Nuclear Air Cleaning systems.")

B. ANSI/ASME N509-1976, "Nuclear Power Plant Air cleaning Units and Components." (This standard was revised and issued as ANSI/ASME N509-1980, "Nuclear Power Plant Air Cleaning Units and Components.")

C. ASTM D2854-83, "Test for Apparent Density of Activated Carbon."

D. ASTM D2862-82, "Test Method for Particle Size Distribution of Granulated Activated Carbon." 
E. MIL-F-51068, "Filter, Particulate, High-Efficiency, Fire-Resistant," Military Specification.

F. MIL-STD-282, "Filter Units, Protective clothing, Gas-Mask Components and Related Products: Performance Test Methods."

G. RDT Standard M 16-1T, "Gas-Phase Adsorbents for Trapping Radioactive Iodine and Iodine Compounds," USAEC Division of Reactor Research and Development, October 1973. (This standard was revised and issued as NE M 16-1T, "Gas-Phase Adsorbents for Trapping Radioactive Iodine and Iodine Compounds," December 1977$.

\subsubsection{Supplemental Information}

1987.

A. NUREG-0800, USNRC "Standard Review Plan," June

system."

1. SRP 9.4.1, "Control Room Area Ventilation

system."

2. SRP 9.4.2, "Spent Fuel Pool Area Ventilation Ventilation system."

3. SRP 9.4.3, "Auxiliary and Radwaste Area

4. SRP 9.4.4, "Turbine Area Ventilation sys-

tem."

5. SRP 9.4.5, "Engineered Safety Feature

Ventilation system."

B. NUREG/CR-0660, "Enhancement of Onsite Emergency Diesel Generators Reliability."

c. "Industrial Ventilation," American Conference of Governmental Industrial Hygienists, 14th Edition, 1976.

D. ERDA :76-21, "Nuclear Air Cleaning Handbook," Oak Ridge National Laboratory, C.A. Burchsted, J.E. Kahn, and A.B. Fuller, March 31, 1976.

E. IE Information Notice 86-76, "Problems Noted in Control Room Emergency Ventilation Systems."

F. IE Information Notice 82-43, "Deficiencies in LWR Air Filtration/ Ventilation Systems." 


\subsection{OTHER AUXILIARY BYSTEMS}

This section identifies criteria pertinent to fire protection, communications, lighting, and auxiliary systems of the emergency diesel generators. Seismic and environmental qualification requirements for other auxiliary systems are identified in sections 3.10 and 3.11 .

9.5.1 Code of Federal Regulations

A. $\quad 10$ CFR 50.48, "Fire Protection."

B. 10 CFR 50.55a, "Codes and Standards."

C. 10 CFR 50, Appendix A, "General Design Criteria for Nuclear Power Plants."

Natural Phenomena."

1. GDC 2, "Design Bases for Protection Against

2. GDC 3, "Fire Protection."

Bases."

3. GDC 4, "Environmental and Missile Design Components."

4. GDC 5, "Sharing of structures, systems and

5. GDC 17, "Electric Power Systems."

6. GDC 44, "Cooling Water."

tems."

7. GDC 45, "Inspection of cooling water sys-

8. GDC 46, "Testing of Cooling Water systems."

D. 10 CFR 50, Appendix R, "Fire Protection Program for Nuclear Power Facilities operating Prior to January 1, 1979."

9.5.2 USNRC Regulatory Guides, SRP Branch Technical Positions and Appendices

A. Regulatory Guide 1.9, "Selection, Design, and Qualification of Diesel Generator Units Used as Standby (Onsite) Electric Power Systems at Nuclear Power Plants."

B. Regulatory Guide 1.26, "Quality Group Classifications and standards for Water-, steam-, and Radioactive-WasteContaining Components of Nuclear Power Plants." 
cation."

c. Regulatory Guide 1.29, "Seismic Design Classifi-

D. Regulatory Guide 1.68, "Initial Test Programs for Water-Cooled Nuclear Power Plants."

E. Regulatory Guide 1.101, "Emergency Planning and Preparedness for Nuclear Power Reactors."

F. Regulatory Guide 1.115, "Protection Against Low Trajectory Turbine Missiles."

cation."

G. Regulatory Guide 1.117, "Tornado Design Classifi-

H. Regulatory Guide 1.120, "Fire Protection Guidelines for Nuclear Power Plants."

I. Regulatory Guide 1.137, "Fuel Oil systems for Standby Diesel Generators."

J. SRP 3.6.1, Branch Technical Position ASB 3-1, "Protection Against Postulated Piping Failures in Fluid systems outside Containment."

K. SRP 3.6.2, Branch Technical Position MEB 3-1, "Postulated Break and Leakage Locations in Fluid system Piping outside Containment."

L. SRP Appendix 8A, Branch Technical Position ICSB-17 (PSB), "Diesel-Generator Protective Trip Circuit Bypasses."

M. SRP 9.5.1, Branch Technical Position CMEB 9.5-1, "Guidelines for Fire Protection for Nuclear Power Plants."

9.5.3 Codes and standards

A. ANSI/ASME B31.1, "Power Piping."

B. API 620-1978, "Recommended Rules for Design and Construction of Large, Welded, Low Pressure storage Tanks." (This standard was revised and issued as ANSI/API 620-1986, "Recommended Rules for: Design and Construction of Large, Welded, Low Pressure storage Tanks." )

C. API 650-1980, "Welded Steel Tanks for Oil storage."

D. ASME Boiler and Pressure Vessel Code.

1. Section III, "Rules for construction of Nuclear Power Plant Components," Division 1. 
2. Section VIII, "Rules for Construction of Pressure Vessels," Division 1.

3. Section XI, "Rules for Inservice Inspection of Nuclear Power Plant Components."

standard.

E. Diesel Engine Manufacturers Association (DEMA)

F. IEEE 279-1971, "Criteria for protection systems for Nuclear Power Generating stations." (This standard was withdrawn on June 14, 1984 and incorporated into ANSI/IEEE 603-1980, "IEEE Standard Criteria for Safety systems for Nuclear Power Generating stations.")

G. IEEE 308-1980, "IEEE Standard Criteria for Class $1 \mathrm{E}$ Power Systems for Nuclear Power Generating Stations."

H. IEEE 383-1974(R1982), "IEEE Standard for Type Test of Class 1E Electric Cables, Field splices and Connections for Nuclear Power Generating stations."

I. IEEE 387-1977, "IEEE Standard Criteria for DieselGenerator Units Applied as Standby Power Supplies for Nuclear Power, Generating stations." (This standard was revised and issued as ANSI/IEEE 387-1984, "IEEE Standard Criteria for DieselGenerator Units Applied as Standby Power Supplies for Nuclear Power Generating stations.")

J. ANSI/IEEE 603-1980, "IEEE standard Criteria for Safety systems for Nuclear Power Generating stations."

9.5.4 Supplemental Information

1987.

A. NUREG-0800, USNRC "Standard Review Plan," June

1. SRP 9.5.1, "Fire Protection Program."

2. SRP 9.5.2, "Communications Systems."

3. SRP 9.5.3, "Lighting Systems."

4. SRP 9.5.4, "Emergency Diesel Engine Fuel Oil storage and Transfer System."

Water system."

5. SRP 9.5.5, "Emergency Diesel Engine cooling system."

6. SRP 9.5.6, "Emergency Diesel Engine Starting 
tion system." 7. SRP 9.5.7, "Emergency Diesel Engine Lubrica-

8. SRP 9.5.8, "Emergency Diesel Engine Combustion Air Intake and Exhaust System."

B. NUREG-0654/FEMA-REP-1, "Criteria for Preparation and Evaluation of Radiological Emergency Response Plans and Preparedness in support of Nuclear Power Plants," USNRC, November 1980.

C. NUREG/CR-0660, "Enhancement of Onsite Emergency Diesel Generator Reliability."

D. IE Bulletin 80-15, "Possible Loss of Emergency Notification System (ENS) with Loss of off-Site Power."

E. IE Circular 80-09, "Problems With Plant Internal Communications systems."

F. IE Information Notice 87-04, "Diesel Generator Fails Test Because of Degraded Fuel." (IE Circular 77-15 discusses the same subject). tions system."

G. IE Information Notice 86-97, "Emergency Communica-

H. IE Information Notice 85-77, "Possible Loss of Emergency Notification System Due to Loss of AC Power."

I. IE Information Notice 85-44, "Emergency Communication System Monthly Test."

J. IE Information Notice 84-09, "Lessons Learned From NRC Inspections of Fire Protection Safe Shutdown Systems, (10 CFR 50, Appendix R)."

K. IE Information Notice 83-83, "Use of Portable Radio Transmitters Inside Nuclear Power Plants."

L. IE Information Notice 83-41, "Actuation of Fire Suppression system Causing Inoperability of Safety-Related Equipment."

M. Illuminating Engineering society Lighting Handbook. MAERP-NELP.IA.

N. "Specifications for Fire Protection of New Plants,"

o. NFPA Fire Protection Handbook. 


\begin{abstract}
P. Underwriters Laboratories Rating List.
Q. "Building Materials Directory," Underwriters Laboratories,
\end{abstract}


This chapter identifies criteria for experimental facilities and steam and power conversion systems. Regulatory Guide 1.70 does not address experimental facilities.

\subsection{EXPERIMENTAL FACILITIES}

One of the principal missions of many DOE reactors is to conduct research and perform experiments. This section identifies criteria for research facilities and conducting experiments.

\subsubsection{Code of Federal Regulations}

A. $\quad 10$ CFR 50.55a, "Codes and Standards."

B. 10 CFR 50.59, "Changes, Tests, and Experiments."

C. 10 CFR 50, Appendix A, "General Design Criteria for Nuclear Power Plants," (Appropriate GDC should be applied depending on the importance to safety of an experimental facility).

D. 10 CFR 50, Appendix B, "Quality Assurance Criteria for Nuclear Power Plants and Fuel Reprocessing Plants," (Appropriate criteria should be applied depending on the importance to safety of an experimental facility).

\subsubsection{USNRC Regulatory Guides, SRP Branch Technical Positions and Appendices}

A. Regulatory Guide 1.26, "Quality Group Classifications and standards for Water-, steam-, and Radioactive-WasteContaining Components of Nuclear Power Plants."

cation."

B. Regulatory Guide 1.29, "Seismic Design Classifi-

C. Regulatory Guide 2.1,; "Shield Test Program for Evaluation of Installed Biological Shielding in Research and Training Reactors."

D. Regulatory Guide 2.4, "Review of Experiments for Research Reactors."

E. Regulatory Guide 2.2, "Development of Technical specifications for Experiments in Research Reactors." 
F. Regulatory Guide 2.5, "Quality Assurance Program Requirements for Research Reactors."

\subsubsection{Codes and standards}

Pulse Reactors."

A. ANSI/ANS 14.1-1975 (R1989), "Operation of Fast

B. ANSI/ANS 15.1-1982, "The Development of Technical Specifications for Research Reactors."

C. ANSI/ANS 15.6-1974, "Review of Experiments for Research Reactors." (This standard was withdrawn in 1983 and its criteria incorporated into ANSI/ANS 15.1-1982, "The Development of Technical specifications for Research Reactors.")

D. ANSI/ANS 15.8-1976(R1986), "Quality Assurance Program Requirements for Research Reactors."

E. ANSI/IEEE 308-1980, "IEEE Standard criteria for Class 1E Power systems for Nuclear Power Generating stations."

F. ANSI/IEEE 603-1980, "IEEE Standard Criteria for Safety systems for Nuclear Power Generating stations."

G. ANSI/ASME B31.1-1986, "Power Piping."

H. ANSI API 620-1978, "Recommended Rules for Design and Construction of Large, Welded, Low Pressure Storage Tanks." (This standard was revised and issued as ANSI/API 620-1986, "Recommended Rules for Design and Construction of Large, Welded, Low-Pressure storage Tanks.")

I. ASME Boiler and Pressure Vessel Code.

1. Section II, "Material Specifications."

2. Section III, "Rules for construction of Nuclear Power Plant Components," Division 1.

3. Section V, "Nondestructive Examination."

4. Section VIII, "Rules for construction of Pressure Vessels," Division 1.

5. Section XI, "Rules for Inservice Inspection of Nuclear Power Plant Components." 
J. IEEE 279-1971, "Criteria for Protection systems for Nuclear Power Generating stations." (This standard was withdrawn on June 14, 1984 and incorporated into ANSI/IEEE 603-1980, "IEEE Standard Criteria for safety systems for Nuclear Power Generating stations.")

\subsection{4 supplemental Information}

None.

10.2 TURBINE GENERATOR

\subsubsection{Code of Federal Regulations}

A. 10 CFR 50.55a, "Codes and Standards."

B. 10 CFR 50, Appendix A, "General Design Criteria for Nuclear Power Plants."

Bases."

1. GDC 4, "Environmental and Missile Design

\subsubsection{USNRC Regulatory Guides, SRP Branch Technical Positions and Appendices}

A. Regulatory Guide 1.68, "Initial Test Programs for Water-Cooled Reactor Power Plants."

B. SRP 3.6.1, Branch Technical Position ASB 3-1, "Protection Against Postulated Piping Failures in Fluid systems outside Containment."

C. SRP 3.6.2, Branch Technical Position MEB 3-1, "Postulated Break and Leakage Locations in Fluid system Piping outside containment."

\subsubsection{Codes and standards}

A. ASME Boiler and Pressure Vessel Code.

1. Section II, "Matêrial Specifications."

2. Section III," "Rules for construction of Nuclear Power Plant Components," Division 1 .

3. Section V," "Nondestructive Examination."

sure Vessels," Division 1. 
5. Section $\mathrm{XI}$, ."Rules for Inservice Inspection of Nuclear Power Plant Components."

B. ASTM E-208-85, "Method for Conducting Drop-Weight Test to Determine Nil-Ductility Transition Temperature of Ferritic Steels."

\subsection{4 supplementary Information}

1987.

A. NUREG-0800, USNRC "Standard Review Plan," June

1. SRP 10.2, "Turbine Generator."

2. SRP 10.2.3, "Turbine Disc Integrity."

B. Scientific Paper 71-1E7-MSLRF-P1, Westinghouse Electric Corp., J.A. Begley and W.A. Logsdon, July 26, 1971.

\subsection{MAIN STEAY SUPPLY SYSTEM}

10.3.1 Code of Federal Regulations

A. 10 CFR 50.55a, "Codes and Standards."

B. 10 CFR 50, Appendix A, "General Design Criteria for Nuclear Power Plants."

1. GDC 1, "Quality Standards and Records."

2. GDC 2, "Design Bases for Protection Against Natural Phenomena."

Bases."

3. GDC 4, "Environmental and Missile Design components."

4. GDC 5, "Sharing of structures, Systems and

5. GDC 34, "Residual Heat Removal."

6. GDC 35, "Emergency Core Cooling."

c. 10 CFR 50, Appendix B, "Quality Assurance Criteria for Nuclear Power Plants and Fuel Reprocessing Plants." 
10.3.2 UsNRC Regulatory Guides, SRP Branch Technical Positions and Appendices

A. Regulatory Guide 1.26, "Quality Group Classifications and standards for Water-, steam-, and Radioactive-WasteContaining Components of Nuclear Power Plants."

cation."

B. Regulatory Guide 1.29, "Seismic Design Classifi-

c. Regulatory Guide 1.31, "Control of Ferrite content in stainless steel Weld Metal."

D. Regulatory Guide 1.36, "Nonmetallic Thermal Insulation for Austenitic stainless steel."

E. Regulatory Guide 1.37, "Quality Assurance Requirements for cleaning of Fluid Systems and Associated Components of Water-Cooled Nuclear Power Plants."

F. Regulatory Guide 1.44, "Control of the Use of Sensitized Stainless steel."

G. Regulatory Guide 1.50, "Control of Preheat Temperature for Welding of Low-Alloy Steel."

H. Regulatory Guide 1.71, "Welder Qualification for Areas of Limited Accessibility."

I. Regulatory Guide 1.85, "Materials code Case Acceptability-ASME Section III, Division 1."

J. Regulatory Guide 1.115, "Protection Against LowTrajectory Turbine Missiles."

cation." K. Regulatory Guide 1.117, "Tornado Design Classifi-

L. SRP 3.6.1, Branch Technical Position ASB 3-1, "Protection Against Postulated Piping Failures in Fluid systems outside Containment."

M. SRP 3.6.2, Branch Technical Position MEB 3-1, "Postulated Rupture Locations in Fluid system Piping Inside and outside Containment."

N. SRP 5.4.7, Branch Technical Position RSB 5-1, "Design Requirements of the Residual Heat Removal System." 


\subsubsection{Codes and standards}

A. ANSI N45.2.1-1980, "Cleaning of Fluid Systems and Associated Components During Construction Phase of Nuclear Power Plants." (This standard was withdrawn on November 21, 1985 and incorporated into ANSI/ASME NQA-2-1986, "Quality Assurance Requirements for Nuclear Power Plants."

$$
\begin{aligned}
& \text { B. ANSI/ASME B31.1-1986, "Power Piping." } \\
& \text { C. ASME Boiler and Pressure Vessel Code. }
\end{aligned}
$$

1. Section II, "Material Specifications."

2. Section III, "Rules for construction of Nuclear Power Plant Components," Division 1.

3. Section VIII, "Rules for Construction of Pressure Vessels," Division 1.

4. Section IX, "Qualification standard for Welding and Brazing Procedures, Welders, Brazers, and Welding and Brazing Operators."

5. Section III, "Code Cases, Nuclear Components."

D. ASTM A-262-86, "Practices for Detecting Susceptability to Intergranular Attack in Austenitic Stainless Steel," Practice E.

E. AWS A4.2-1974, "Standard Procedures for Calibrating Magnetic Instruments to Measure the Delta Ferrite content of Austenitic stainless steel Weld Metal." (This standard was revised and issued as ANSI/AWS A4.2-1986, "Procedures for Calibrating Magnetic Instruments to Measure the Delta Ferrite Content of Austenitic stainless Steel Weld Metals.")

F. AWS A5.4-1978, "specification for corrosionResisting Chromium and Chromium Nickel steel covered Welding Electrodes." (This standard was revised and issued as ANSI/AWS A5.4-1981, "Specification for Corrosion-Resisting Chromium and Chromium Nickel. Steel Welding Electrodes.")

10.3.4 supplemental Information

1987 .

A. NUREG-0800, USNRC "Standard Review Plan," June

Materials.

1. SRP 10.3, "Main steam Supply System."

2. SRP 10.3.6," "steam and Feedwater system 
B. NUREG-0138, "Staff Discussion of Fifteen Technical Issues Listed in Attachment to November 3, 1976, Memorandum from Director NRR to NRR Staff," USNRC, November 1976.

\subsection{OTHER FEATURES OF STEAM AND PONER CONVERSION}

\subsubsection{Code of Federal Regulations}

A. $\quad 10$ CFR 50.55a, "Codes and Standards."

B. 10 CFR 50, Appendix A, "General Design Criteria for Nuclear Power Plants."

1. GDC 1, "Quality Standards and Records."

2. GDC 2, "Design Bases for Protection Against Natural Phenomena."

Bases."

3. GDC 4, "Environmental and Missile Design Components."

4. GDC 5, "Sharing of structures, Systems and tems."

5. GDC 14, "Reactor Coolant Pressure Boundary."

6. GDC 19, "Control Room."

7. GDC 34, "Residual Heat Removal:"

8. GDC 44, "Cooling Water."

9. GDC 45, "Inspection of cooling water sys10. GDC 46, "Testing of Cooling Water Systems."

11. GDC 60, "Control of Releases of Radioactive Materials to the Environment.".:

12. GDC 64, "Monitoring Radioactivity Releases."

10.4.2 UBNRC Regulatory Guides, SRP Branch Technical Positions and Appendices

A. Regulatory Guide 1.26, "Quality Group Classifications and standards for Water-, steam-, and Radioactive-Wastecontaining components of Nuclear Power Plants." 
cation."

B. Regulatory Guide 1.29, "Seismic Design Classifi-

C. Regulatory Guide 1.33, "Quality Assurance Program Requirements (Operation)."

D. Regulatory Guide 1.56, "Maintenance of Water Purity in Boiling water Reactors."

E. Regulatory Guide 1.123, "Quality Assurance Requirements for Control of Procurement of Items and Services for Nuclear Power Plants."

F. Regulatory Guide 1.143, "Design Guidance for Radioactive Waste Management systems, structures, and components Installed in Light-Water-Cooled Nuclear Power Plants."

G. SRP 5.4.2.1, Branch Technical Position MTEB 5-3, "Monitoring of Secondary side Water Chemistry in PWR steam Generators."

H. SRP 5.4.7, Branch Technical Position RSB 5-1, "Design Requirements of the Residual Heat Removal System."

I. SRP 10.4.9, Branch Technical Position ASB 10-1, "Design Guidelines for Auxiliary Feedwater System Pump Drive and Power Supply Diversity for Pressurized Water Reactor Plants."

J. SRP 10.4.7, Branch Technical Position ASB 10-2, "Design Guidelines for Avoiding Water Hammer in steam Generators."

\subsubsection{Codes and standards}

A. ANSI/ACI 349-1980, "Code Requirements for Nuclear Safety-Related Concrete structures" and ACI 349R-1980," "Commentary."

B. ANSI/ASME B31.1, "Power Piping."

C. ANSI/ASME N45.2.13-1976, "Quality Assurance Requirements for Control of Procurement of Items and Services for Nuclear Power Plants:" (This standard was withdrawn April 15, 1983 and incorporated into ANSI/ASME NQA-1-1986, "Quality Assurance Program Requirements for Nuclear Facilities.")

D. ANS 3.2-1976, "Administrative Controls and Quality Assurance for the Operational Phase of Nuclear Power Plants." (This standard was revised and issued as ANSI/ANS 3.2-1988, "Administrative Controls and Quality Assurance for the Operational Phase of Nuclear Power Plants.") 
E. ASME Boiler and Pressure Vessel Code.

1. Section II, "Material Specifications."

2. Section III, "Rules for construction of Nuclear Power Plant Components," Division 1.

3. Section VIII, "Rules for Construction of Reactor Vessels," Division 1.

4. Section IX, "Qualification standard for Welding and Brazing procedures, Welders, Brazers, and Welding and Brazing Operators."

5. Section XI, "Rules for Inservice Inspection of Nuclear Power Plant Components."

10.4.4 Supplemental Information

1987.

A. NUREG-0800, USNRC, "Standard Review Plan," June

tem."

1. SRP 10.4.1, "Main Condenșers."

2. SRP 10.4.2, "Main Condenser Evacuation Sys-

3. SRP 10.4.3, "Turbine Gland Sealing system."

4. SRP 10.4.4, "Turbine Bypass System."

5. SRP 10.4.5, "Circulating water System."

6. SRP 10.4.6, "Conde"nsate cleanup System."

tem."

7. SRP 10.4.7, "Condensate and Feedwater sys-

"

(PWR) . "

8. SRP 10.4.8, "Steam Generpator Blowdown system

(PWR)."

9. SRP 10.4.9,

"Auxiliary "Fe"edwatepsystem

(PWR) ."

B. NUREG-0737, "Clarification of TMI Action Plan Requirements," USNRC, November 1980.

C. "Standards for Steam Surface Condensers," 6th Ed., Heat Exchanger Institute, 1970. 


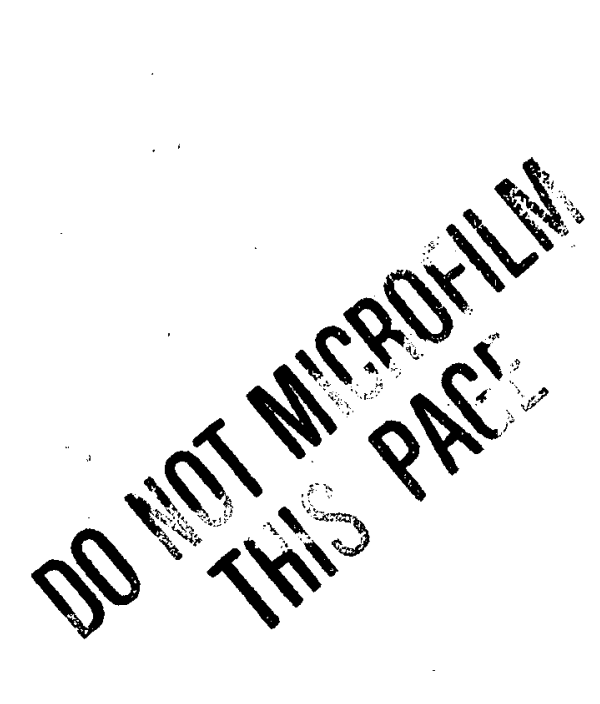

2

$$
10-10
$$

$10-10$

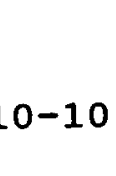

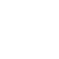

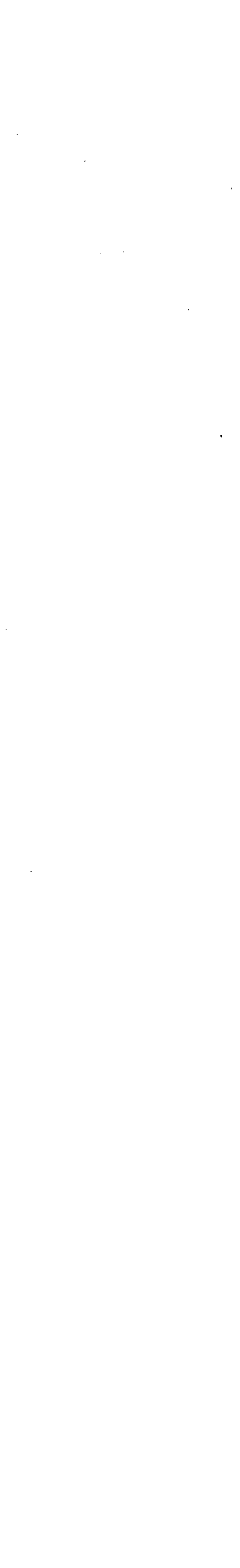


CHAPTER 11

RADIOACTIVE WASTE MANAGEMENT

\subsection{SOURCE TERMS}

\subsubsection{Code of Federal Regulations}

A. 10 CFR 20.1, "Purpose." Information."

B. 10 CFR 50.34, "Contents of Applications; Technical

C. 10 CFR 50.34a, "Design Objectives for Equipment to Control Releases of Radioactive Material in Effluents - Nuclear Power Reactors."

D. 10 CFR 50, Appendix A, "General Design Criteria for Nuclear Power Plants."

1. GDC 60, "Control of Releases of Radioactive Materials to the Environment."

2. GDC 64, "Monitoring Radioactivity Releases."

E. 10 CFR 50, Appendix I, "Numerical Guides for Design objectives and Limiting Conditions for operation to Meet the Criterion 'As Low As is Reasonably Achievable' for Radioactive Material in Light-Water-Cooled Nuclear Power Reactor Effluents."

11.1.2 U8NRC Regulatöry Guides, SRP Branch Technical Positions and Appendices

A. Regulatory Guide 1.110," Cost-Benefit Analysis for Radwaste Systems for Light-Water-Cooled Nuclear Power Reactors."

B. Regulatory Guide 1.112," "Calculation of Releases of Radioactive Materials in Gaseous and Liquid Effluents from Light-Water-Cooled Power Reactors."

C. Regulatory Guide 1.140, "Design, Testing, and Maintenance Criteria for Normal Ventilation Exhaust system Air Filtration and Adsorption Units of Light-Water-Cooled Nuclear Power Plants." 


\subsubsection{Codes and standards}

A. ANSI N237-1976, "Source Term Specification." (This standard was revised and issued as ANSI/ANS 18.1-1984, "Radioactive Source Term for Normal Operation of Light Water Reactors.")

B. ANSI N510-1975, "Testing of Nuclear Air cleaning systems." (This standard was revised and issued as ANSI/ASME N510-1980, "Testing of Nuclear Air Cleaning Systems.")

C. ANSI/ANS 18.1-1984, "Radioactive Source Term for Normal Operation of Light Water Reactors."

D. ANSI/ASME N509-1976, "Nuclear Power Plant Air Cleaning Units and Components." (This standard was revised and issued as ANSI/ASME N509-1989, "Nuclear Power Plant Air Cleaning Units and Components.")

of Activated Carbon."

E. ASTM D2854-83, "Test Method for Apparent Density

F. ASTM D2862-82, "Test Method for Particle Size Distribution of Granulated Activated Carbon."

G. MIL-STD-282, "Filter Units, Protective clothing, Gas-Mask Components and Related Products: Performance-Test Methods."

Fire-Resistant."

H. MIL-F-51068, "Filter, Particulate, High-Efficiency,

I. RDT M 16-1T, "Gas-Phase Adsorbents for Trapping Radioactive Iodine and Iodine Compounds," October 1973. (This standard was revised and issued as NE M 16-1T, "Gas phase Adsorbents for Trapping Radioactive Iodine and Iodine compounds," December 1977.$)$

\subsubsection{Supplemental Information}

1987.

A. NUREG-0800, USNRC "Standard Review Plan," June

\section{SRP 11.1, "Source Terms."}

B. NUREG-0017, "Calculation of Releases of Radioactive Materials in Gaseous and Liquid Effluents from Pressurized Water Reactors (PWRs)," USNRC, April 1985.

C. NUREG-0016, Rev. 1, "Calculation of Releases of Radioactive Materials in Gaseous and Liquid Effluents from Boiling Water Reactors (BWRs)," USNRC, December 1978. 
D. "Industrial Ventilation," 14th Edition, American Conference of Governmental Industrial Hygienists, 1976.

E. ERDA 76-21, "Nuclear Air Cleaning Handbook," Oak Ridge National Laboratory, C.A. Burchsted, J.E. Kahn, and A.B. Fuller, March 31, 1976.

\subsection{LIQUID WASTE MANAGEMENT SY8TEMS}

\subsubsection{Code of Federal Regulations}

A. Commission Policy statement, "Low-Level Waste Volume Reduction," 46 FR 51100, October 16, 1981.

B. 10 CFR 20.106, "Radioactivity in Effluents to Unrestricted Areas."

tion."

C. 10 CFR 20.305, "Treatment or Disposal by Incinera-

D. 10 CFR 20.306, "Disposal of Specific Wastes."

E. 10 CFR 20, Appendix B, "Concentrations in Air and Water Above Natural Background."

F. 10 CFR 50.34a, "Design Objectives for Equipment to Control Releases of Radioactive Material in Effluents - Nuclear Power Reactors."

G. 10 CFR 50.36a, "Technical specifications on Effluents from Nuclear Power Reactors."

H. $\quad 10$ CFR 50.55a, "Codes and Standards."

I. 10 CFR 50, Appendix A, "General Design Criteria for Nuclear Power Plants."

1. GDC 60, "Control of Releases of Radioactive Materials to the Environment."

Radioactivity Control."

2. GDC 61, "Fuel storage and Handing and

3. GDC 64, "Monitoring Radioactivity Releases."

J. 10 CFR 50, Appendix I, "Numerical Guides for Design objectives and Limiting conditions for operation to Meet the Criterion 'As Low. As is Reasonably Achievable' for Radioactive Material in Light-Water-Cooled Nuclear Power Reactor Effluents." 
11.2.2 USNRC Regulatory Guides, SRP Branch Technical Positions. and Appendices

A. Regulatory Guide 1.26, "Quality Group Classifications and standards for Water-, Steam-, and Radioactive- WasteContaining Components of Nuclear Power Plants."

cation."

B. Regulatory Guide 1.29, "Seismic Design Classifi-

C. Regulatory Guide 1.110, "Cost Benefit Analysis for Radwaste Systems for Light-Water-Cooled Nuclear Power Reactors."

D. Regulatory Guide 1.143, "Design Guidance for Radioactive Waste Management Systems, structures and Components Instalied in Light-Water-Cooled Nuclear Power Plants."

\subsubsection{Codes and standards}

A. ANSI/ANS 55.6-1979, "Liquid Radioactive Waste Processing system for Light Water Reactor Plants."

B. ANSI/API 620-1978, "Rules for Design and Construction of Large, Welded, Low Pressure storage Tanks." (This standard was revised and issued as ANSI/API 620-1986," "Recommended Rules for Design and Construction of Large, Welded, Low-Pressure storage Tanks.")

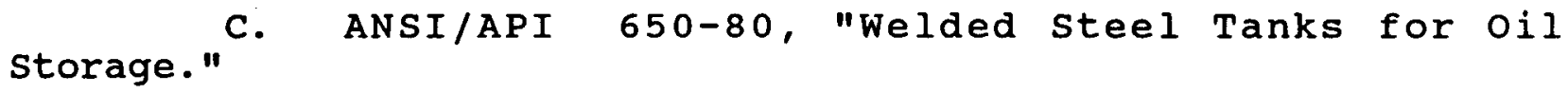

D. ANSI/ASME B31.1, "Power Piping."

E. ANSI/AWWA D100-84, "Welded steel Tanks for Water
storage."

F. ASME Boiler and Pressure Vessel Code.

1. Section II, "Material Specifications."

2. Section III, "Rules for construction of Nuclear Power Plant Components," Division 1.

3. Section VIII, "Rules for Construction of Pressure Vessels," Division 1.

4. Section IX, "Qualification Standard for Welding and Brazing Procedures, Welders, Brazers, and Welding and Brazing Operators." 


\subsection{4 supplemental Information}

June 1987 .

A. NUREG-0800, USNRC "standard Review Plan,"

B. SRP 11.2, "Liquid Waste Management Systems."

C. NUREG-0017, "Calculation of Releases of Radioactive Materials in Gaseous and Liquid Effluents from Pressurized Water Reactors (PWRs)," USNRC, April 1985.

D. NUREG-0016, Rev. 1, "Calculation of Releases of Radioactive Materials in Gaseous and Liquid Effluents from Boiling Water Reactors (BWRs)," USNRC, December 1978.

\subsection{GA8EOUS WASTE MANAGEMENT BY8TEMS}

\subsubsection{Code of Federal Regulations}

A. 10 CFR 20.106, "Radioactivity in Effluents in Unrestricted Areas."

B. 10 CFR 20, Appendix B, "Concentrations in Air and Water Above Natural Background."

C. 10 CFR 50.34a, "Design Objective for Equipment to Control Releases of Radioactive Materials in Effluents - Nuclear Power Reactors."

D. 10 CFR $50.36 \mathrm{a}$, "Technical specifications on Effluents from Nuclear Power Reactors."

E. $\quad 10$ CFR 50.55a, "Codes and Standards."

F. 10 CFR 50, Appendix A, "General Design Criteria for Nuclear Power Plants."

1. GDC 3, "Fire Protection."

2. GDC 60, "Control of Releases of Radioactive Material to the Environment."

3. GDC 61, "Fuel storage and Handling and Radioactivity Control."

G. 10 CFR 50, Appendix I, "Numerical Guides for Design objectives and Limiting conditions for operation to Meet the Criterion 'As Low As is Reasonably Achievable' for Radioactive Material in Light-Water-Cooled Nuclear Power Reactor Effluents." 
11.3.2 U8NRC Regulatory Guides, BRP Branch Technical Positions and Appendices

A. Regulatory Guide 1.140, "Design, Testing, and Maintenance Criteria for Normal Ventilation Exhaust system Air Filtration and Adsorption Units of Light-Water-Cooled Nuclear Power Plants."

B. Regulatory Guide 1.143, "Design, Guidance for Radioactive waste Management systems, Structures and Components Installed in Light-Water-Cooled Nuclear Power Plants."

C. SRP 11.3, Branch Technical Position ETSB 11-5, "Postulated Radioactive Releases Due to a Waste Gas system Leak or Failure."

\section{$11.3 .3^{\circ}$ Codes and standards}

A. ANSI N510-1975, "Testing of Nuclear Air Cleaning systems." (This standard was revised and issued as ANSI/ASME N510-1980, "Testing of Nuclear Air Cleaning systems.")

B. ANSI/ANS 55.4-1979, "Gaseous Radioactive Waste Processing systems for Light water Reactor Plants."

c. ANSI/ASME N509-1976, "Nuclear Power Plant Air cleaning Units and Components." (This standard was revised and issued as ANSI/ASME N509-1980, "Nuclear Power Plant Air Cleaning Units and Components.")

D. API 620-1978, "Rules for Design and Construction of Large, Welded, Low-Pressure storage Tanks." (This standard was revised and issued as ANSI/API 620-1986, "Recommended Rules for Design and Construction of Large, Welded, Low-Pressure storage Tanks.")

Storage."

E. ANSI/API 650-1980, "Welded steel Tanks for oil

F. ANSI/ASME B31.1, "Power Piping."

storage."

G. ANSI/AWWA D100-84, "Welded Steel Tanks for Water

H. ASME Boiler and Pressure Vessel Code.

1. Section II, "Material Specifications."

2. Section III, "Rules for construction of Nuclear Power Plant Components," Division 1. 
3. Section IX, "Qualification standard for Welding and Brazing Procedures, Welders, Brazers, and Welding and Brazing operators."

I. ASTM D2854-83, "Test Method for Apparent Density of Activated Carbon.".

J. ASTM D2862-82, "Test Method for Particle size Distribution of Granulated Activated Carbon."

K. MIL-STD-282, "Filter Units,, Protective clothing, Gas-Mask Components and Related Products: Performance-Test Methods."

Fire-Resistant."

L. MIL-F-51068, "Filter, Particulate, High-Efficiency,

M. RDT M 16-1T, "Gas-Phase Adsorbents for Trapping Radioactive Iodine and Iodine Compounds," October 1973. (This standard was revised and issued as NE M 16-1T, "Gas-Phase Adsorbents for Trapping Radioactive Iodine and Iodine compounds," December 1977.)

\subsubsection{Bupplemental Information}

1987.

A. NUREG-0800, "USNRC "Standard Review Plan," June

$$
\text { 1. SRP 11.3, "Gaseous Waste Management Systems." }
$$

B. NUREG-0017, "Calculation of Releases of Radioactive Materials in Gaseous and Liquid Effluents from Pressurized Water Reactors (PWRs)," USNRC, April 1985.

C. NUREG-0016, "Calculation of Releases of Radioactive Materials in Gaseous and Liquid Effluents from Boiling Water Reactors (BWRs)," USNRC, December 1978.

D. ERDA 76-21, "Nuclear Air cleaning Handbook," Oak Ridge National Laboratory, C.A. Burchsted, J.E. Kahn, and A.B. Fuller, March 31, 1976.

\subsection{SOLID WASTE MANAGEMENT SYSTEMS}

\subsubsection{Code of Federal Regulations}

A. Commission Policy statement, "Low-Level Waste Volume Reduction," 46 FR 51100, October 16, 1981. 
B. 10 CFR 20.106, "Radioactivity in Effluents to Unrestricted Areas."

tion."

C. 10 CFR 20.305, "Treatment or Disposal by Incinera-

D. 10 CFR 20.306, "Disposal of specific Wastes."

E. 10 CFR 20, Appendix B, "Concentrations in Air and Water Above Natural Background."

F. 10 CFR 50.34a, "Design Objectives for Equipment to Control Releases of Radioactive Material in Effluents - Nuclear Power Reactors."

G. 10 CFR 50.36a, "Technical specifications on Effluents from Nuclear Power Reactors."

H. 10 CFR 50.55a, "Codes and Standards."

I. 10 CFR 50, Appendix A, "General Design Criteria for Nuclear Power Plants."

1. GDC 60, "Control of Releases of Radioactive Materials to the Environment."

2. GDC 63, "Monitoring Fuel and Waste Storage."

3. GDC 64, "Monitoring Radioactivity Releases."

J. 10 CFR 71, "Packaging and Transportation of Radioactive Material."

11.4.2 USNRC Regulatory Guides, SRP Branch Technical Positions and Appendices

A. Regulatory Guide 1.26, "Quality Group Classifications and Standards for Water-, Steam-, and Radioactive-WasteContaining Components of Nuclear Power Plants."

cation."

B. Regulatory Guide 1.29, "Seismic Design Classifi-

C. Regulatory Guide 1.143, "Design Guidance for Radioactive Waste Management Systems, Structures and Components Installed in Light-Water-Cooled Nuclear Power Plants."

D. SRP 11.4, Branch Technical Position ETSB 11-3, "Design Guidance for Solid Radioactive Waste Management Systems Installed in Light-Water-Cooled Nuclear Power Reactor Plants.". 
E. SRP 11.4, Appendix A, "Design Guidance for Temporary on-site storage of Low-Level Radioactive Waste."

\subsubsection{Codes and standards}

A. ANSI/ANS 55.1-1979," "Solid Radioactive waste Processing System for Light Water Reactor Plants."

B. ANSI/API. 620-1978, "Rules for Design and Construction of Large, Welded, Low-Pressure storage Tanks." (This standard was revised and issued as ANSI/API 620-1986," Recommended Rules for Design and Construction of Large, Welded, Low-Pressure Storage Tanks.")

storage."

C. ANSI/API 650-1980, "Welded steel Tanks for Oil

D. ANSI/ASME B31.1, "Power Piping."

storage."

E. ANSI/AWWA D100-84, "Welded steel Tanks for Water

F. ASME Boiler and Pressure Vessel Code.

1. Section II, "Material specifications."

2. section III, "Rules for construction of Nuclear Power Plant Components," Division 1.

3. Section IX, "Qualification Standard for Welding and Brazing Procedures, Welders, Brazers, and Welding and Brazing Operators."

\subsection{4 supplemental Information}

1987.

A. NUREG-0800, USNRC "Standard Review Plan," June

1. 11.4, "Solid Waste Management Systems."

B. IE Information Notice 85-92," "Surveys of Waste Before Disposal from Nuclear, Reactor Facilities."

C. IE Information Notice 85-46, "Clarification of Several Aspects of Removable Radioactive surface contamination Limits for Transport. Packages."

D. IE Information Notice 84-14, "Highlights of Recent Transport Regulatory Revisions by DOT and NRC." 
E. IE Information Notice 83-10, "Clarification of Several Aspects Related to Use of NRC Certified Transport Packages."

F. IE Information Notice 80-32, "Clarification of Certain Requirements for Exclusive-Use Shipments of Radioactive Materials."

G. IE Information Notice 80-24, "Low-Level Radioactive Waste Burial Criteria."

11.5 PROCESS AND EFFLUENT RADIOLOGICAL MONITORING AND SAMPLING BY8TEMS

11.5.1 Code of Federal Regulations

A. 10 CFR 20.106, "Radioactivity in Effluents to Unrestricted Areas."

B. $\quad 10$ CFR 50.36b, "Environmental Conditions."

C. 10 CFR 50, Appendix A, "General Design Criteria for Nuclear Power Plants."

1. GDC 60, "Control of Releases of Radioactive Materials to the Environment."

2. GDC 63, "Monitoring Fuel and Waste Storage."

3. GDC 64, "Monitoring Radioactivity Releases."

11.5.2 USNRC Regulatory Guides, 8RP Branch Technical Positions and Appendices

A. Regulatory Guide 1.21, "Measuring, Evaluating, and Reporting Radioactivity in solid Wastes and Releases of Radioactive Materials in Liquid and Gaseous Effluents from LightWater-Cooled Nuclear Power Plants."

B. Regulatory Guide 1.97, "Instrumentation for Light-water-Cooled Nuclear Power Plants to Assess Plant and Environs Conditions During and Following an Accident."

c. Regulatory Guide 4.15, "Quality Assurance for Radiological Monitoring Programs (Normal Operations) - Effluent Streams and the Environment." 
D. SRP 11.5, Appendix A, "Design Guidance for Radiological Effluent Monitors Providing signals for Initiating Termination of Flow or Other Modification of Effluent stream Properties."

\subsubsection{Codes and standards}

A. ANSI N13.1-1969(R1982), "Guide to Sampling Airborne Radioactive Materials in Nuclear Facilities."

B. ANSI N13.10-1974, "Specification and Performance of on-site Instrumentation for Continuously Monitoring Radioactivity in effluents." (This standard was reissued as ANSI. N42.18-1980(R1985), "Specification and Performance of On-Site Instrumentation for continuously Monitoring Radioactivity in Effluents.")

C. ANSI N42.14-1978(R1985), "Calibration and Usage of Germanium Detectors for Measurement of Gamma-Ray Emission of Radionuclides."

\subsubsection{Bupplemental Information}

1987.

A. NUREG-0800, USNRC "Standard Review Plan," June

1. SRP 11.5, "Process and Effluent Radiological Monitoring Instrumentation and Sampling Systems."

B. NUREG-0017, "Calculation of Releases of Radioactive Materials in Gaseous and Liquid Effluents From Pressurized Water Reactors, (PWRs)," USNRC, April 1985.

C. NUREG-0718, "Licensing Requirements for Pending Applications for Construction Permits and Manufacturing License," USNRC, March 1981.

D. NUREG-0737, "Clarification of TMI Action Plan Requirements," USNRC, November 1980.

E. NUREG-0016, "Calculation of Releases of Radioactive Materials in Gaseous and Liquid Effluents from Boiling Water Reactors (BWRs)," USNRC, December 1978.

F. WASH 1258, Vol. 1, "Final Environmental statement Numerical Guides for Design objectives and Limiting Conditions for Operation to Meet the Criterion 'As Low As Practicable' for Radioactive Material in Light-Water-Cooled Nuclear Power Reactor Effluents," July 1973.

G. IE Information Notice 82-49, "Correction of Sample Conditions for Air and Gas Monitoring." 
H. NCRP Report No. 58, "A Handbook of Radioactivity Measurements Procedures," National Council of Radiation Protection, 1978. 


\section{RADIATION PROTECTION}

The criteria identified in this chapter are for radiation protection. of operating, construction, and maintenance personnel during normal and anticipated operational occurrences. The compilation includes criteria for facility equipment design, planning and procedures programs, and the techniques and practices used to meet the standards for protection against radiation of 10 CFR 20 .

\subsection{ASSURING THAT OCCUPATIONAL EXPOSURES ARE AS LOW AS REA- SONABLY ACHIEVABLE}

\subsubsection{Code of Federal Regulations}

A. Commission Policy statement, "Enforcement Policy Regarding Occupational Doses From 'Hot Particles'," 55 FR 31113, July 31, 1990.

B. 10 CFR 19.12, "Instructions to Workers."

C. $\quad 10$ CFR 20.1(c), "Purpose."

Information."

D. 10 CFR 50.34, "Contents of Applications; Technical

E. 10 CFR 50, Appendix I, "Numerical Guides for Design objectives and Limiting conditions for operation to Meet the Criterion 'As Low as is Reasonably Achievable' for Radioactive Material in Light-Water-Cooled Nuclear Power Reactor Effluents."

\subsubsection{USNRC Regulatory Guides, SRP Branch Technical Positions and Appendices}

A. Regulatory Guide 1.8, "Qualification and Training of Personnel for Nuclear Power Plants."

B. Regulatory Guide 8.8, "Information Relevant to Ensuring that Occupational Radiation Exposures at Nuclear Power stations will Be as Low as is Reasonably Achievable."

C. Regulatory Guide 8.10, "Operating Philosophy for Maintaining Occupational Radiation Exposures as Low as is Reasonably Achievable." 


\subsubsection{Codes and standards}

A. ANSI/ANS 3.1-1981, "Selection, Qualification, and Training of Personnel for Nuclear Power Plants." (This standard was revised and issued as ANSI/ANS 3.1-1987," "selection, Qualification, and Training of Personnel for Nuclear Power Plants.")

B. ANSI/ANS 15.11-1987, "Radiation Protection at Research Reactor Facilities."

c. ANSI/ANS 55.1-1979, "Solid Radioactive Waste Processing System for Light-Water-Cooled Reactor Plants."

D. ANSI/ANS 55.4-1979, "Gaseous Radioactive Waste Processing Systems for Light water Reactor Plants."

E. ANSI/ANS 55.6-1979, "Liquid Radioactive Waste Processing system for Light water Reactor Plants."

\subsection{4 supplemental Information}

1987.

A. NUREG-0800, USNRC "Standard Review Plan," June

1. SRP 12.1, "Assuring That Occupational Radiation Exposures Are as Low as is Reasonably Achievable."

B. NUREG-0761, "Contents of Radiation Protection Plans for Nuclear Power Reactor Licensees," USNRC, March 1981.

C. NUREG-0041, "Manual of Respiratory Protection Against Airborne Radioactive Materials," USNRC, October 1976.

D. NUREG/CR-2963, "Planning Guidance for Nuclear Power Plant Decontamination," Pacific Northwest Laboratory, June 1983.

\subsection{RADIATION SOURCES}

\subsubsection{Code of Federal Regulations}

A. 10 CFR 20.101, "Radiation Dose Standards for Individuals in Restricted Areas."

B. 10 CFR 20.103, "Exposure of Individuals to Concentrations of Radioactive Materials in Air in Restricted Areas."

C. 10 CFR 20.104, "Exposure of Minors." Unrestricted Areas."

D. 10 CFR 20.106, "Radioactivity in Effluents to 
E. 10 CFR 20.207, "Storage and Control of Licensed Materials in Unrestricted Areas."

Information."

F. 10 CFR 50.34, "Contents of Applications; Technical

G. 10 CFR 50, Appendix A, "General Design Criteria for Nuclear Power Plants."

1. GDC 61, "Fuel storage and Handing and Radioactivity Control."

12.2.2 U8NRC Regulatory Guides and BRP Branch Technical Positions and Appendices

The method of calculating $x / Q$ values in Regulatory Guides 1.3 and 1.4 is superseded by the method presented in Regulatory Guide 1.145, "Atmospheric Dispersion Models for Potential Accident Consequence Assessments at Nuclear Power Plants."

A. Regulatory Guide 1.3, "Assumptions Used for Evaluating the Potential Radiological Consequences of a Loss-ofCoolant Accident for Boiling Water Reactors."

B. Regulatory" Guide 1.4, "Assumptions Used for Evaluating the Potential Radiological Consequences of a Loss-ofCoolant Accident for Pressurized Water Reactors."

C. Regulatory Guide 1.7, "Control of Combustible Gas Concentrations in Containment Following a Loss-of-Coolant Accident."

D. Regulatory Guide 1.112, "Calculation of Releases of Radioactive Materials in Gaseous and Liquid Effluents from Light-Water-Cooled Power Reactors." "...

E. Regulatory Guide 1.145, "Atmospheric Dispersion Models for Potential Accident Consequence Assessments at Nuclear Power Plants."

\subsubsection{Codes and standards}

A. ANSI N237-1976, "Source Term Specification." (This standard was revised and issued as ANSI/ANS 18.1-1984, "Radioactive Source Term for Normal Operation of Light Water Reactors.")

B. ANSI/ANS 18.1-1984, "Radioactive Source Term for Normal Operation of Light-Water Reactors." 


\subsubsection{Bupplemental Information}

1987.

A. NUREG-0800, USNRC "Standard Review Plan," June

1. SRP 12.2, "Radiation Sources."

B. NUREG-0017, "Calculation of Releases of Radioactive Materials in Gaseous and Liquid Effluents from Pressurized Water Reactors (PWRs)," USNRC, April 1985.

C. NUREG-0718, "Licensing Requirements for Pending Applications for Construction Permits and Manufacturing License," USNRC, March 1981.

D. NUREG-0737, "Clarification of TMI Action Plan Requirements," Item II.B.2, USNRC, November 1980 .

E. NUREG-0016, "Calculation of Releases of Radioactive Materials in Gaseous and Liquid Effluents from Boiling Water Reactors (BWRs)," USNRC, December 1978.

F. IE Information Notice 78-08, "Radiation Levels from Fuel Element Transfer Tubes."

12.3 RADIATION PROTECTION DESIGN FEATÚRES

12.3.1 Code of Federal Regulations

A. 10 CFR 20.1(c), "Purpose."

B. 10 CFR 20.101, "Radiation Dose Standards for Individuals in Restricted Areas."

C. 10 CFR 20.103, "Exposure of Individuals to Concentrations of Radioactive Materials in Air in Restricted Areas."

D. 10 CFR 20.104," Exposure of Minors."

E. 10 CFR 20.203, "Caution, signs, Labels, Signals, and Controls."

F. 10 CFR 20.207," "Storage and control of Licensed Materials in Unrestricted Areas."

G. 10 CFR 50.34a, "Design Objectives for Equipment to Control Releases of Radioactive Material in Effluents - Nuclear Power Reactors."

H. 10 CFR 50, Appendix A, "General Design Criteria for Nuclear Power Plants." 
Radioactivity Control."

$$
\text { 1. GDC 19, "Control Room." }
$$

3. GDC 63, "Monitoring Fuel and Waste Storage." I. 10 CFR 70.24, "Criticality Accident Requirements."

12.3.2 UsNRC Regulatory Guides and BRP Branch Technical Positions and Appendices

A. Regulatory Guide 1.21, "Measuring, Evaluating, and Reporting Radioactivity in solid wastes and Releases of Radioactive Materials in Liquid and Gaseous Effluents from LightWater-Cooled Nuclear Power Plants."

B. Regulatory Guide 1.52, "Design, Testing, and Maintenance Criteria for Post Accident Engineer-Safety-Feature Atmosphere cleanup System Air Filtration and Adsorption Units of Light-Water-Cooled Nuclear Power Plants."

C. Regulatory Guide 1.69, "Concrete Radiation Shields for Nuclear Power Plants."

D. Regulatory Guide 1.97, "Instrumentation for Light-Water-Cooled Nuclear Power Plants to Assess Plant and Environs Conditions During and Following an Accident."

E. Regulatory Guide 2.1, "Shield Test Program for Evaluation of Installed Biological Shielding in Research and Training Reactors."

F. Regulatory Guide 8.2, "Guide for Administrative Practices in Radiation Monitoring."

G. Regulatory Guide 8.8, "Information Relevant to Ensuring That Occupational Radiation Exposures at Nuclear Power stations will Be as .Low as is Reasonably. Achievable."

H. Regulatory Guide 8.10, "Operating Philosophy for Maintaining occupational Radiation Exposures as Low as is Reasonably Achievable." ". Alarm systems."

I. Regulatory Guide 8.12 , "Criticality Accident

J. Regulatory Guide 8.19, "occupational Radiation Dose Assessment in Light-Water Reactor Power Plants Design Stage Man-Rem Estimates." 


\subsubsection{Codes and standards}

A. ANSI N13.1-1969 (R1982), "Guide to Sampling Airborne Radioactive Materials in Nuclear Facilities."

B. ANSI N13.2-1969 (R1988), "Guide for Administrative Practices in Radiation Monitoring."

C. ANSI N16.2-1969, "Criticality Accident Alarm System." (This standard was revised and issued as ANSI/ANS 8.31979, "Criticality Accident Alarm System;" subsequent revisions to the 1979 standard produced two standards, ANSI/ANS 8.3-1986, "Criticality Accident Alarm System" and ANSI/ANS 8.19-1984, "Administrative Practices for Nuclear Criticality Safety," that include the relevant features of N16.2-1969.)

D. ANSI N18.9-1972, "Program for Testing Biological Shielding in Nuclear Reactor Plants." (This standard was revised and issued as ANSI/ANS 6.3.1-1987, "Program for Testing Radiation Shields in Light water Reactors (LWR).")

E. ANSI N101.2-1972, "Protective Coatings (Paints) for Light water Nuclear Reactor Containment Facilities." (This standard was withdrawn in 1983 and replaced by the "Manual of Coating work for Light-Water Nuclear Power Plant Primary Containment and other Safety-Related Facilities," ASTM, 1979.)

F. ANSI N101.6-1972, "Concrete Radiation Shields." (This standard was withdrawn in 1981; it was replaced by ANSI/ACI 349-80 and 349R-80, "Code Requirements for Nuclear Safety Related Concrete Structures" and ANSI/ANS 6.4-1985, "Guidelines on the Nuclear Analysis and Design of Concrete Radiation Shielding for Nuclear Power Plants.")

G. ANSI N510-1975, "Testing of Nuclear Air cleaning systems." (This standard was revised and issued as ANSI/ASME N510-1980, "Testing of Nuclear Air cleaning Systems.")

H. ANSI/ACI 349-80, "Code Requirements for Nuclear Safety-Related Concrete structures," and ACI 349R-80, "Commentary."

I. ANSI/ANS 4.5-1980(R1986), "Criteria for Accident Monitoring Functions in Light-Water-Cooled Reactors."

J.. ANSI/ANS 6.3.1-1987, "Program for Testing Radiation Shields in Light-Water Reactors (LWR)."

K. ANSI/ANS 6.4-1985, "Guidelines on the Nuclear Analysis and Design of Concrete Radiation Shielding for Nuclear Power Plants." 
L. ANSI/ANS-HPSSC 6.8.1-1981, "Location and Design Criteria for Area Radiation Monitoring Systems for Light Water Nuclear Reactors."

system."

M. ANSI/ANS 8.3-1986, "Criticality Accident Alarm

N. ANSI/ANS 8.19-1984, "Administrative Practices for Nuclear Criticality Safety."

O. ANSI/ANS 15.11-1987, "Radiation Protection at Research Reactor Facilities."

P. ANSI/ANS 55.1-1979, "Solid Radioactive waste Processing System for Light-Water-Cooled Reactor Plants."

Q. ANSI/ANS 55.4-1979, "Gaseous Radioactive Waste Processing Systems for Light water Reactor Plants."

R. ANSI/ANS 55.6-1979, "Liquid Radioactive Waste Processing System for Light Water Reactor Plants."

S. ANSI/ASME N509-1976, "Nuclear Power Plant Air cleaning Units and Components." (This standard was revised and issued as ANSI/ASME N509-1980, "Nuclear Power Plant Air Cleaning Units and Components.")

\subsection{4 supplemental Information}

1987.

A. NUREG-0800, USNRC "Standard Review Plan," June

Features."

1. SRP 12.3-12.4, "Radiation Protection Design

B. NUREG-0718, "Licensing Requirements for Pending Applications for Construction Permits and Manufacturing License (Item II.B.2.)," USNRC, March 1981.

C. NUREG-0737, "Clarification of TMI Action Plan Requirements," Item II.F.1.3, USNRC, November 1980.

D. IE Information Notice 78-08, "Radiation Levels from Fuel Element Transfer Tubes."

E. "Manual of Coating Work for Light-Water Nuclear Power plant primary Containment and other Safety-Related Facilities," ASTM, 1979. 
F. ERDA 76-21, "Nuclear Air cleaning Handbook," C.A. Burchsted, J.E. Kahn, and A.B. Fuller, Oak Ridge National Laboratory, March 31, 1976.

12.4 DOSE A88ES8MENT

12.4.1 Code of Federal Regulations

A. Commission Policy statement, "Enforcement Policy Regarding Occupational Doses From 'Hot Particles'," 55 FR 31113, July 31, 1990. Information."

B. 10 CFR 50.34, "Contents of Applications; Technical

12.4.2 USNRC Regulatory Guides, SRP Branch Technical Positions and Appendices

A. Regulatory Guide 8.19, "Occupational Radiation Dose Assessment in Light-Water Reactor Power Plants Design Stage Man-Rem Estimates."

12.4.3 Codes and standards

None.

12.4.4 supplementary Information

1987.

A. NUREG-0800, USNRC "Standard Review Plan," June

Features."

1. SRP 12.3-12.4, "Radiation Protection Design

B. IE Information Notice 83-59, "Dose Assignment for Workers in Non-Uniform Radiation Fields."

12.5 HEALTH PHYBICS (OPERATIONAL RADIATION PROTECTION) PROGRAM

12.5.1 Code of Federal Regulations

A. 10 CFR 19.12, "Instructions to Workers."

B. 10 CFR 20.1 (c), "Purpose."

C. 10 CFR 20.101, "Radiation Dose Standards for Individuals in Restricted Areas." 
D. 10 CFR 20.103, "Exposure of Individuals to concentrations of Radioactive Materials in Air in Restricted Areas."

E. 10 CFR 20.105, "Permissible Levels of Radiation in Unrestricted Areas."

F. $\quad 10$ CFR 20.201, "Surveys."

G. 10 CFR 20.202, "Personnel Monitoring."

H. 10 CFR 20.203 and 20.204, "Caution, Signs, Labels, Signals, and Controls."

I. 10 CFR 20.205, "Procedures for Picking Up, Receiving, and Opening Packages."

J. 10 CFR 20.207," "Storage and Control of Licensed Materials in Unrestricted Areas."

K. 10 CFR 20.401, "Records of surveys, Radiation Monitoring, and Disposal."

Licensed Material."

L. 10 CFR 20.402, "Reports of Theft or Loss of

M. 10 CFR 20.405, "Reports of Overexposures and Excessive Levels and Concentrations."

N. 10 CFR 20.408, "Reports of Personnel Monitoring on Termination of Employment or Work."

O. 10 CFR 50, Appendix A, "General Design Criteria for Nuclear Power Plants."

1. GDC 64, "Monitoring Radioactivity Releases."

\subsubsection{USNRC Regulatory Guides, SRP Branch Technical Positions and Appendices}

A. Regulatory Guide 1.8, "Qualification and Training of Personnel for Nuclear Power Plants."

B. Regulatory Guide 1.16, "Reporting of operating Information --Appendix A, Technical Specifications."

C. Regulatory Guide 1.33, "Quality Assurance Program Requirements (Operation)."

D. Regulatory Guide 1.39, "Housekeeping Requirements for Water-Cooled Nuclear Power Plants." 
E. Regulatory Guide 1.97, "Instrumentation for Light-Water-Cooled Nuclear Power Plants to Assess Plant and Environs Conditions During and Following an Accident."

F. Regulatory Guide 8.2, "Guide for Administrative Practices in Radiation Monitoring."

Criteria."

G. Regulatory Guide 8.3, "Film Badge Performance

H. Regulatory Guide 8.4," "Direct-Reading and Indirect-Reading Pocket Dosimeters."

I. Regulatory Guide 8.6, "Standard Test Procedure for Geiger-Muller Counters."

J. Regulatory Guide 8.7, "Occupational Radiation Exposure Records Systems."

K. Regulatory Guide 8.8, "Information Relevant to Ensuring That Occupational Radiation Exposures at Nuclear Power stations Will Be as Low as is Reasonably Achievable."

L. Regulatory Guide 8.9, "Acceptable Concepts, Models, Equations, and Assumptions for a Bioassay Program."

M. Regulatory Guide 8.10, "Operating Philosophy for Maintaining Occupational Radiation Exposures as Low as is Reasonably Achievable."

Alarm systems."

N. Regulatory Guide 8.12, "Criticality Accident

0. Regulatory Guide 8.13, "Instruction Concerning Prenatal Radiation Exposure."

P. Regulatory Guide 8.14, "Personnel Neutron Dosimeters."

Q. Regulatory Guide 8.15, "Acceptable Programs for Respiratory Protection."

R. Regulatory Guide 8.20, "Applications of Bioassay for I-125 and I-131."

S. Regulatory Guide 8.26, "Applications of Bioassay for Fission and Activation Products."

T. Regulatory Guide 8.27, "Radiation Protection Training for Personnel at Light-Water-Cooled Nuclear Power Plants." 
Dosimeters."

U. Regulatory Guide 8.28, "Audible Alarm

V. Regulatory Guide 8.29, "Instruction Concerning Risks from Occupational Radiation Exposure."

Tritium Bioassay Program."

W. Regulatory Guide 8.32, "Criteria for Establishing a 12.5.3 Codes and standards

A. ANSI N13.2-1969 (R1988), "Guide for Administrative Practices in Radiation Monitoring."

B. ANSI N13.5-1972 (R1989), "Performance specifications for Direct-Reading and Indirect-Reading Pocket Dosimeters for $\mathrm{X}$ - and Gamma Radiation."

C. ANSI N13.6-1972 (R1989), "Practice for Occupational Radiation Exposure Records Systems."

D. ANSI N13.7-1983 (R1989), "Criteria for Photographic Film Badge Dosimeter Performance."

E. ANSI N13.27-1981, "Performance Requirements for Pocket-sized Alarm Dosimeters and Alarm Ratemeters."

F. ANSI N18.7-1976, "Quality. Assurance Program Requirements (Operational)." (This standard was revised and issued as ANSI/ANS 3.2-1982, "Administrative Controls and Quality Assurance for the Operational Phase of Nuclear Power Plants.")

G. ANSI N42.3-1969, "Test Procedure for Geiger-Muller counters." (This standard was redesignated ANSI/IEEE 309-1984, "IEEE Standard Test Procedure for Geiger-Muller Counters.")

H. ANSI N45.2.3-1973, "Housekeeping During the Construction Phase of Nuclear Power Plants." (This standard was withdrawn March 21, 1984 and incorporated into NQA-2-1986, "Quality Assurance Requirements for Nuclear Power Plants.")

I. ANSI N101.2-1972, "Protective Coatings (Paints) for Light-Water Nuclear Reactor Containment Facilities." (This standard was withdrawn in 1983 and replaced by the "Manual of Coating work for Light-Water Nuclear Power Plant Primary Containment and other Safety-Related Facilities," ASTM., 1979.)

J. ANSI N237-1976, "Source Term specification." (This standard was revised and issued as ANSI/ANS 18.1-1984, "Radioactive Source Term for Normal operation of Light Water Reactors.") 
K. ANSI N319-1976(R1984), "Personnel Neutron Dosimeters (Neutron Energies Less Than $20 \mathrm{MeV}$ )."

L. ANSI N343-1978(R1984), "Internal Dosimetry for Mixed Fission and Activation Products."

M. ANSI/ANS 3.1-1981, "Selection, Qualification, and Training of Personnel for Nuclear Power Plants." (This standard was revised and issued as ANSI/ANS 3.1-1987," "selection, Qualification, and Training of Personnel for Nuclear Power Plants.")

N. ANSI/ANS 4.5-1980(R1986), "Criteria for Accident Monitoring Functions in Light-Water-Cooled Reactors."

0. ANSI/ANS 8.3-i979, "Criticality Accident Alarm system." (This standard was revised and its relevant features issued in two standards, ANSI/ANS 8.3-1986, "Criticality Accident Alarm System" and ANSI/ANS 8.19-1984, "Administrative Practices for Nuclear Criticality Safety.")

P. ANSI/ANS 8.19-1984, "Administrative Practices for Nuclear Criticality Safety."

Q. ANSI/ANS 15.11-1987," "Radiation Protection at Research Reactor Facilities."

R. ANSI/ANS 18.1-1984, "Radioactive Source Term for Normal Operation of Light Water Reactors."

S. ANSI/ANS 55.1-1979," "Solid Radioactive Waste Processing System for Light-Water-cooled Reactor Plants."

T. ANSI/ANS 55.4-1979, "Gaseous Radioactive waste Processing Systems for Light Water Reactor Plants."

U. ANSI/ANS 55.6-1979, "Liquid Radioactive waste Processing system for Light Water Reactor Plants."

V. ANSI/IEEE 309-1970(R1984), "IEEE standard Test Procedure for Geiger-Muller Counters."

W. ANS 3.2-1976, "Administrative Controls and Quality Assurance for the Operational Phase of Nuclear Power Plants." (This standard was revised and issued as ANSI/ANS 3.2-1988, "Administrative Controls and Quality Assurance for the operational Phase of Nuclear Power Plants.") 


\subsection{4 supplemental Information}

1987.

A. NUREG-0800, USNRC "Standard Review Plan," June

Program."

1. SRP 12.5, "Operational Radiation Protection

B. NUREG-0041, "Manual of Respiratory Protection Against Airborne Radioactive Materials," USNRC, October 1976.

C. NUREG-0718, "Licensing Requirements for Pending Applications for Construction Permits and Manufacturing License," Item III. D.3.3, USNRC, March 1981.

D. NUREG-0737, "Clarification of TMI Action Plan Requirements," Item III. D.3.3, USNRC, November 1980.

E. NUREG-0731, "Guidelines for Utility Management Structure and Technical Resources," USNRC.

F. NUREG-0938, "Information for Establishing Bioassay Measurements and Evaluations of Tritium Exposure."

G. IE Informationf Notice 85-46, "Clarification of Several Aspects of Removable Radioactive Surface contamination Limits for Transport Packages. "f/

Radiation Areas."

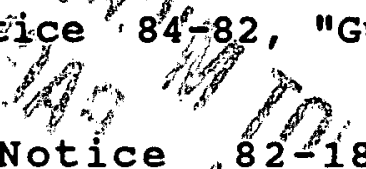

I. IE Information Notice, $82-18$, Assessment of Intakes of Radioactive Material by Workers"

J. IE Information Notice 81-26, "Use of Recirculating Mode Self-Contained Breathing Apparatus (Rebreathers)."

K. "Manual of Coating work for Light-water Nuclear Power plant Primary containment and other safety-Related Facilities." ASTM, 1979. 


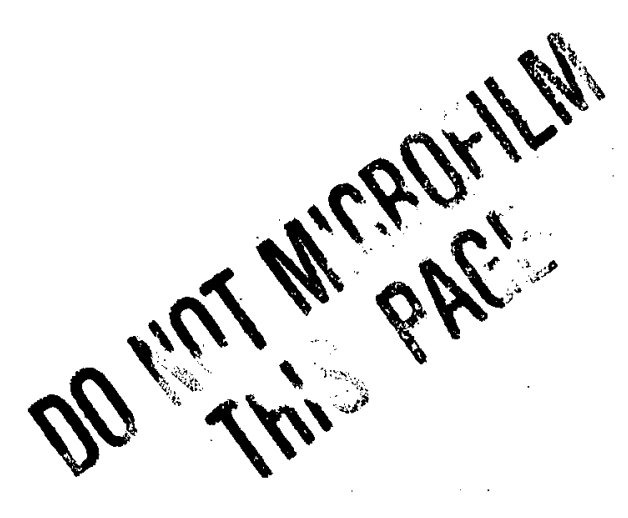

$12-14$

\author{
$12-14$
}




\section{CONDUCT OF OPERATIONS}

The criteria identified in this chapter address the organizational structure, training, emergency planning, review and audit functions, and plant procedures. The NRC industrial security criteria identified are not considered part of the nuclear safety criteria and are provided as information. For DOE reactors, the criteria for industrial security are provided by other DOE organizations.

\subsection{ORGANIZATIONAL STRUCTURE}

The criteria identified in this section are for the following: management and technical support organizations, the operating organization, and the qualifications of personnel.

\subsubsection{Code of Federal Regulations}

A. Commission Policy statement, "Policy Regarding Nuclear Power Plant Staff Working Hours," 47 FR 7352, February 18,1982 .

B. Commission Policytatement, "Engineering Expertise On Shift," 50 FR 43621, October 28, 1985.

C. Commission Policy statement, "Conduct of Nuclear Power Plant Operations," 54 FR 3424, January 24, 1989.

D. Commission Policy statement, "Education for senior Reactor Operators and Shift Supervisors at Nuclear Power Plants," 54 FR 33639, August 15, 1989. Information."

E. 10 CFR 50.34, "Contents of Applications; Technical

F. 10 CFR 50.54, "Conditions of Licenses."

G. 10 CFR 55, "Operators' Licenses."

13.1.2 USNRC Regulatory Guides; SRP Branch Technical Positions and Appendices

A. Regulatory Guide 1.8, "Qualification and Training of Personnel for Nuclear Power Plants." Requirements (Operation)."

B. Regulatory Guide 1.33, "Quality Assurance Program 
C. Regulatory Guide 1.68, "Initial Test Programs for Water-Cooled Nuclear Power Plants."

D. Regulatory Guide 1.114, "Guidance to operators at the controls and to senior operators in the control Room of a Nuclear Power Unit."

E. Regulatory Guide 1.134, "Medical Evaluation of Licensed Personnel for Nuclear Power Plants."

F. SRP 9.5.1, Branch Technical Position CMEB 9.5-1, "Guidelines for Fire Protection for Nuclear Power Plants."

\subsubsection{Codes and standards}

A. ANSI/ANS 3.1-1981, "Selection, Qualification, and Training of Personnel for Nuclear Power Plants." (This standard was revised and issued as ANSI/ANS 3.1-1987," "Selection, Qualification, and Training of Personnel for Nuclear Power Plants.")

B. ANSI/ANS 3.4-1983, "Medical certification and Monitoring of Personnel Requiring operator Licenses for Nuclear Power Plants."

c. ANSI/ISA S67.14-1983, "Qualifications and Certification of Instrumentation and Control Technicians in Nuclear Power Plants."

D. ANS 3.2-1976, "Administrative Controls and Quality Assurance for the Operational Phase of Nuclear Power Plants." (This standard was revised and issued as ANSI/ANS 3.2-1988, "Administrative Controls and Quality Assurance for the Operational Phase of Nuclear Power Plants.")

\subsection{4 supplemental Information}

1987.

A. NUREG-0800, USNRC "Standard Review Plan," June Organization." $1 . \quad$ SRP 13.1.1, "Management and Technical Support 2. SRP 13.1.2-13.1.3, "Operating Organization."

B. NUREG-0718, "Licensing Requirements for Pending Applications for Construction Permits and Manufacturing License," USNRC, March 1981. 
C. NUREG-0737, "Clarification of TMI Action Plan Requirements," USNRC, November 1980.

D. NUREG-0694, "TMI-Related Requirements for New Operation Licenses," USNRC, June 1980.

E. IE Bulletin 74-11, "Improper Wiring of Safety Injection Logic at Zion 1 and $2 . "$

F. IE Circular 81-02, "Performance of NRC Licensed Individuals while on Duty."

G. IE Circular 80-22, "Confirmation of Employee Qualifications."

crews."

H. IE Circular 80-21, "Regulation of Refueling

I. IE Information Notice 87-65, "Plant Operation Beyond Analyzed Conditions."

J. IE Information Notice 87-21, "Shutdown order Issued Because Licensed Operators Asleep While on Duty."

K. IE Information Notice 86-77, "Computer Program Error Report Handling."

L. IE Information Notice 85-66, "Discrepancies Between As-Built Construction Drawings and Equipment Installations."

M. IE Information Notice 85-11, "Licensee Programs for Inspection of Electrical Raceway and Cable Installations." tection."

N. IE Information Notice 84-08, "Employee Pro-

0. IE Information Notice 80-28, "Prompt Reporting of Information in Accordance with 10 CFR 50.55(e)."

P. IE Information Notice 80-26, "Evaluation of Contractor QA Programs."

Q. IE Information Notice 79-30, "Reporting of Defects and Noncompliances, 10 CFR Part 21." 


\subsection{TRAINING}

\subsubsection{Code of Federal Regulations}

A. Commission Policy statement, "Training and Qualification of Nuclear Power Plant Personnel," 50 FR 11147, March 20, 1985 .

B. Amended Commission Policy statement, "Training and Qualifications of Nuclear Power Plant Personnel," 53 FR 46603, November 18,1988 .

C. Commission Policy statement, "Education for senior Reactor operators and Shift Supervisors at Nuclear Power Plants," 54 FR 33639, August 15, 1989.

D. 10 CFR 19.12, "Instructions to Workers."

E. 10 CFR 50.34, "Content of Applications; Technical Information."
F. 10 CFR 50.54, "Conditions of Licenses."
G. $\quad 10$ CFR 55, "Operators' Licenses."

\subsubsection{USNRC Regulatory Guides, SRP Branch Technical Positions and Appendices}

A. Regulatory Guide 1.8, "Qualification and Training of Personnel for Nuclear Power Plants."

B. Regulatory Guide 1.149, "Nuclear Power Plant Simulation Facilities for Use in Operator License Examinations."

C. SRP 9.5.1, Branch Technical Position CMEB 9.5-1, "Guidelines for Fire Protection for Nuclear Power Plants."

\subsubsection{Codes and standards}

A. ANSI/ANS 3.1-1981, "Selection, Qualification, and Training of Personnel for Nuclear Power Plants." (This standard was revised and issued as ANSI/ANS 3.1-1987," "selection, Qualification, and Training of Personnel for Nuclear Power Plants.")

B. ANSI/ANS 3.5-1985, "Nuclear Power Plant Simulators for Use in Operator Training."

C. ANSI/ANS 15.4-1988, "Selection and Training of Personnel for Research Reactors." 
D. ANSI/ISA S67.14-1983, "Qualifications and Certification of Instrumentation and Control Technicians in Nuclear Power Plants."

\subsection{4 supplemental Information}

1987.

A. NUREG-0800, USNRC "Standard Review Plan," June

staff."

1. SRP 13.2.1, "Reactor Operator Training."

2. SRP 13.2.2, "Training for Non-Licensed Plant

B. NUREG-0718, "Licensing Requirements for Pending Applications for Construction Permits and Manufacturing License," Items I.A.4.2 and II.B.4, USNRC, March 1981.

C. NUREG-0737, "Clarification of TMI Action Plan Requirements," Items I.A.1.1 and I.A.2.1, USNRC, November 1980.

D. NUREG-0660, "NRC Action Plan Developed as a Result of the TMI-2 Accident," Item I.A.2.2, USNRC, Vol. 1, MaY 1980 and Vol. 1, Rev. 1, August 1980.

E. NUREG-0094, "A Guide for the Licensing of Facility operators, Including Senior Operators," USNRC, July 1976.

F. WASH-1130, "Utility staffing and Training for Nuclear Power," USAEC, Revised June 1973.

G. IE Information Notice 87-22, "Operator Licensing Requalification Examinations at Non-Power Reactors."

Deficiencies."

H. IE Information Notice 84-11, "Training Program

\subsection{EMERGENCY PLANNING}

13.3.1 Code of Federal Regulations

A. Commission Policy statement, "Planning Basis for Emergency Responses to Nuclear Power Reactor Accidents," 45 FR 2893, January 15, 1980.

B. Commission Policy statement, "Emergency Planning Medical Services," 51 FR 32904, September 17, 1986.

Information."

C. 10 CFR 50.34, "Contents of Applications -Technical 
D. 10 CFR 50.47, "Emergency Plans."

E. 10 CFR 50.54, "Conditions of Licenses."

F. 10 CFR 50.72, "Immediate Notification Requirements for Operating Nuclear Power Reactors."

G. 10 CFR 50, Appendix E, "Emergency Planning and Preparedness for Production and Utilization Facilities."

H. 10 CFR 50, Appendix I, "Numerical Guides for Design objectives and Limiting Conditions for Operation to Meet the Criterion 'As Low As is Reasonably Achievable' for Radioactive Material in Light-Water-Cooled Nuclear Power Reactor Effluents."

I. 10 CFR 100.3, "Definitions."

J. 10 CFR 100.11, "Determination of Exclusion Area, Low Population Zone, and Population Center Distance."

\subsubsection{USNRC Regulatory Guides, SRP Branch Technical Positions and Appendices}

A. Regulatory Guide 1.97, "Instrumentation for Light-Water-Cooled Nuclear Power Plants to Assess Plant and Environs Conditions During and Following an Accident."

B. Regulatory Guide 1.101, "Emergency Planning and Preparedness for Nuclear Power Reactors."

C. Regulatory Guide 1.109, "Calculation of Annual Doses to Man From Routine Releases of Reactor Effluents for the Purpose of Evaluating Compliance with 10 CFR 50, Appendix I."

Research and Test Reactors."

D. Regulatory Guide 2.6, "Emergency Planning for

\subsubsection{Codes and standards}

A. ANSI/ANS 3.7.1-1979, "Facilities and Medical Care for Onsite Nuclear Power Plant Radiological Emergencies." (This standard was withdrawn on August 10, 1987 and replaced by ANSI/ANS 3.8.1-1987, "Criteria for Emergency Response Functions and Organizations.")

B. ANSI/ANS 3.7.2-1979, "Emergency Control Centers for Nuclear Power Plants." (This standard was withdrawn on August 7, 1987 and replaced by ANSI/ANS 3.8.2-1987, "Criteria for Functional and Physical Characteristics of Emergency Response Facilities.") 
C. ANSI/ANS 3.7.3-1979, "Radiological Emergency Preparedness Exercises for Nuclear Power Plants." (This standard was revised and redesignated ANSI/ANS 3.8.3-1987, "Criteria for Emergency Response Plans and Implementing Procedures.")

D. ANSI/ANS 3.8.1-1987, "Criteria for Emergency Response Functions and Organizations."

E. ANSI/ANS 3.8.2-1987, "Criteria for Functional and Physical Characteristics of Emergency Response Facilities."

F. ANSI/ANS 3.8.3-1987, "Criteria for Emergency Response Plans and Implementing Procedures."

G. ANSI/ANS 4.5-1980(R1986), "Criteria for Accident Monitoring Functions in Light-Water-Cooled Reactors."

Research Reactors."

H. ANSI/ANS 15.16-1982, "Emergency Planning for

13.3.4 Supplemental Information

1987.

A. NUREG-0800, USNRC "Standard Review Plan," June

\section{SRP 13.3, "Emergency Planning."}

B. NUREG-0849, "Standard Review Plan for the Review and Evaluation of Emergency Plans for Research and Test Reactors," USNRC, October 1983.

C. NUREG-0718, "Licensing Requirements for Pending Applications for Construction Permits and Manufacturing License," Appendix B, Sections I.D.2, III.A.1.2, and III.A.2, USNRC, March 1981 .

D. NUREG-0696, "Functional Criteria for Emergency Response Facilities," USNRC, February 1981.

E. NUREG-0654/FEMA-REP-1, Revision 1, "Criteria for Preparation and Evaluation of Radiological Emergency Response Plans and Preparedness in support of Nuclear Power Plants," USNRC, November 1980.

F. NUREG-0396 (EPA 520/1-78-016), "Planning Basis for the Development of State and Local Government Radiological Emergency Response Plans in support of Light-Water Nuclear Power Plants," USNRC, December 1978.

G. IE Information Notice 87-58, "Continuous Communications Following Emergency Notifications." 
H. IE Information Notice 87-54, "Emergency Response Exercises."

I. IE Information Notice 86-98, "Offsite Medical Services."

J. IE Information Notice 86-64, "Deficiencies in Upgrade Programs for Plant Emergency Operating Procedures."

K. IE Information Notice 85-80, "Timely Declaration of an Emergency Class, Implementation of an Emergency Plan, and Emergency Notifications."

L. IE Information Notice 85-78 (Supersedes IN 8334), "Event Notification."

M. IE Information Notice 85-77, "Possible Loss of Emergency Notification System Due to Loss of AC Power."

N. IE Information Notice 85-55, "Revised Emergency Exercise Frequency Rule."

O. IE Information Notice 85-41, "Scheduling of Prelicensing Emergency Preparedness Exercises."

P. IE Information Notice 85-27, "Notifications to the NRC Operation Center and Reporting Events in Licensee Event Reports."

Q. IE Information Notice 84-40, "Emergency Worker Doses."

quency."

R. IE Information Notice 84-05, "Exercise Fre-

S. IE Information Notice 83-28, "Criteria for Protective Action Recommendations for General Emergencies."

T. IE Information Notice 82-44, "Clarification of Emergency Plan Exercise Requirements."

U. IE Information Notice 81-03, "Checklist for Licensees Making Notifications of significant Events in Accordance with 10 CFR 50.72." significant Events."

V. IE Information Notice 80-06, "Notification of 


\subsection{REVIEW AND AUDIT}

13.4.1 Code of Federal Regulations
A. 10 CFR 50.55, "Conditions of Construction Permits."
B. 10 CFR 50.59, "Changes, Tests, and Experiments."

\subsubsection{USNRC Regulatory Guides, SRP Branch Technical Positions and Appendices}

A. Regulatory Guide 1.8, "Qualification and Training of Personnel for Nuclear Power Plants."

B. Regulatory Guide 1.33, "Quality Assurance Program Requirements (Operation)."

\subsubsection{Codes and standards}

A. ANSI/ANS 3.1-1981, "Selection, Qualification, and Training of Personnel for Nuclear Power Plants." (This standard was revised and issued as ANSI/ANS 3.1-1987," "selection, Qualification, and Training of Personnel for Nuclear Power Plants.")

B. ANSI/ANS 3.2-1976, "Administrative controls and Quality Assurance for the operational Phase of Nuclear Power Plants." (This standard was revised and issued as ANSI/ANS 3.21988, "Administrative Controls and Quality Assurance for the Operational Phase of Nuclear Power Plants.")

\subsubsection{Supplemental Information}

1987.

A. NUREG-0800, USNRC "Standard Review Plan," June

$$
\text { 1. SRP 13.4, "Operational Review." }
$$

B. NUREG-0737, "Clarification of TMI Action Plan Requirements," Item I.B.1.2, USNRC, November 1980.

Verification."

C. IE Information Notice 84-51, "Independent

\subsection{PLANT PROCEDURES}

13.5.1 Code of Federal Regulations

Information."

A. 10 CFR 50.34, "Contents of Applications; Technical 


\section{B. 10 CFR 50.54, "Conditions of Licenses."}

13.5.2 USNRC Regulatory Guides, SRP Branch Technical Positions and Appendices

A. Regulatory Guide 1.33, "Quality Assurance Program Requirements (Operation)."

B. SRP 13.5.2, Appendix A, "Review Procedures for the Evaluation of Procedures Generation Packages."

\subsubsection{Codes and standards}

A. ANSI/ANS 3.1-1981, "Selection, Qualification, and Training of Personnel for Nuclear Power Plants." (This standard was revised and issued as ANSI/ANS 3.1-1987, "selection, Qualification, and Training of Personnel for Nuclear Power Plants.")

Cranes."

B. ANSI/ASME

B30.2-1983, "Overhead and Gantry

C. ANS 3.2-1976, "Administrative Controls and Quality Assurance for the Operational Phase of Nuclear Power Plants." (This standard was revised and issued as ANSI/ANS 3.2-1988, "Administrative Controls and Quality Assurance for the Operational Phase of Nuclear Power Plants.")

13.5.4 supplemental Information

1987.

A. NUREG-0800, USNRC "Standard Review Plan," June

1. SRP 13.5.1, "Administration Procedures."

2. SRP 13.5.2, "Operating and Maintenance Proce-

dures."

B. NUREG-0899, "Guidelines for Preparation of Emergency Operating Procedures," USNRC, August 1982.

c. NUREG-0737, "Clarification of TMI Action Plan Requirements," USNRC, November 1980 and supplement 1, January 1983 .

D. NUREG-0694, "TMI-Related Requirements for New Operation Licenses," USNRC, June 1980.

E. NUREG-0660, "NRC Action Plan Developed As a Result of the TMI-2 Accident," USNRC, Vol. 1, May 1980 and Vol. 1, Rev. 1 , August 1980 . 
F. NUREG-0578, "TMI-2 Lessons Learned Task Force Status Report and Short-Term Recommendations," USNRC, July 1979.

G. IE Bulletin 75-04, "Cable Fire at Brown's Ferry Nuclear Power station."

Work Hours."

H. IE Circular 80-02, "Nuclear Power Plant staff

I. IE Information Notice 86-55, "Delayed Access to Safety-Related Areas and Equipment During Plant Emergencies."

Problems."

J. IE Information Notice 85-74, "Station Battery

K. IE Information Notice 85-56, "Inadequate Environment control for Components and systems in Extended storage or Layup."

L. IE Information Notice 85-53, "Performance of NRC-Licensed Individuals While on Duty."

M. IE Information Notice 79-09, "Spill of Radioactively Contaminated Resin."

\subsection{INDUSTRIAL SECURITY}

Physical protection plans and detailed security measures for DOE reactor facilities are provided by others. These features for NRC reactor facilities are described in a separate section which is withheld from public disclosure pursuant to 10 CFR $2.790(d)$, "Rules of Practice." The referenced material in this section is provided for information only.

\subsubsection{Code of Federal Regulations}

A. Commission Policy statement, "Nuclear Power Plant Access Authorization Program," 53|FR 7534, March 9, 1988.

sonnel."

B. 10 CFR 25, "Access Authorization for Licensee Per-

C. 10 CFR 50.34, "Contents of Applications, Technical Information."

D. 10 CFR 50.54, "Conditions of Licenses."

E. $\quad 10$ CFR 50.70, "Inspections." 
F. 10 CFR 73.55, "Requirements for Physical Protection of Licensed Activities in Nuclear Power Reactors Against Radiological Sabotage."

G. 10 CFR 73, Appendix B, "General Criteria for Security Personnel." tingency Plans."

H. 10 CFR 73, Appendix C, "Licensee Safeguards Con-

I. 10 CFR 95, "Security Facility Approval and Safeguarding of National security Information and Restricted Data."

\subsubsection{USNRC Regulatory Guides, SRP Branch Technical Positions and Appendices}

A. Regulatory Guide 1.17, "Protection of Nuclear Power Plants Against Industrial Sabotage."

B. Regulatory Guide 5.7, "Entry/Exit Control for Protected Areas, Vital Areas, and Material Areas."

C. Regulatory Guide 5.12, "General Use of Locks in the Protection and control of Facilities and special Nuclear Material."

D. Regulatory Guide 5.20, "Training, Equipping, and Qualifying of Guards and watchmen."

Duties."

E. Regulatory Guide 5.43, "Plant security Force Systems." F. Regulatory Guide 5.44, "Perimeter Intrusion Alarm

G. Regulatory Guide 5.54, "Standard Format and content of Safeguards Contingency Plans for Nuclear Power Plants."

H. Regulatory Guide 5.65, "Vital Areas Access Controls, Protection of Physical security Equipment, and Key and Lock Controls."

\subsubsection{Codes and standards}

Plants."

A. ANSI/ANS 3.3-1982, "Security for Nuclear Power 
13.6.4 Supplemental Information

A. NUREG-0800, USNRC "Standard Review Plan," June 1987. 1. SRP 13.6, "Physical Security."

B. NUREG-0674, "security Personnel Training and Qualification Criteria," USNRC.

USNRC.

c. NUREG-0416, "Security Plan Evaluation Report,"

D. NUREG-0220, "Interim Acceptance criteria for a Physical security Plan for Nuclear Power Plants," USNRC.

E. NUREG-0219, "Nuclear Security Personnel for Power Plants," USNRC.

F. NUREG-0207, "Interim Format and content for a Physical security Plan for Nuclear Power Plants," USNRC, February 1977.

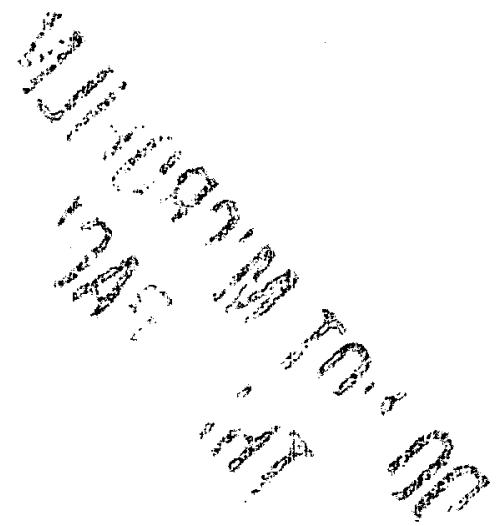




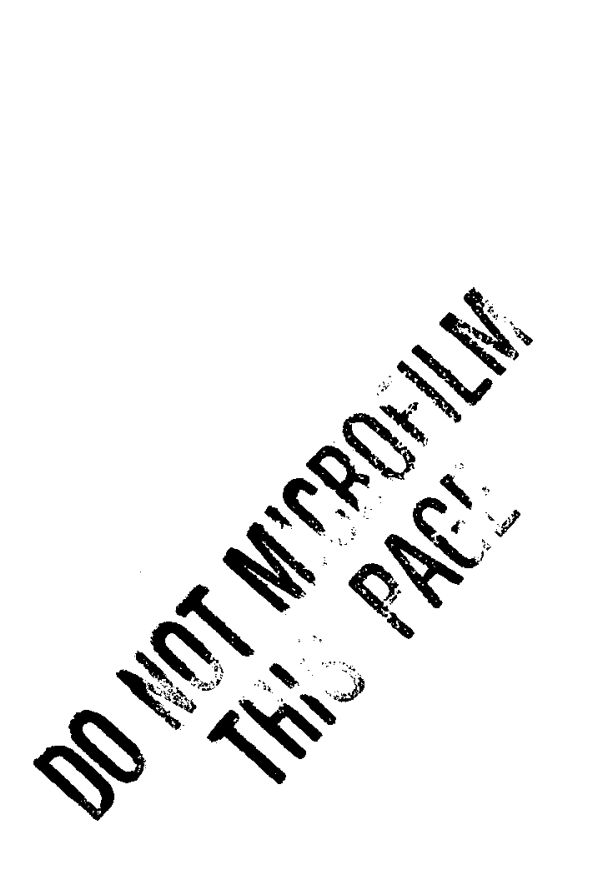

\author{
$13-14$ \\ $13-14$
}
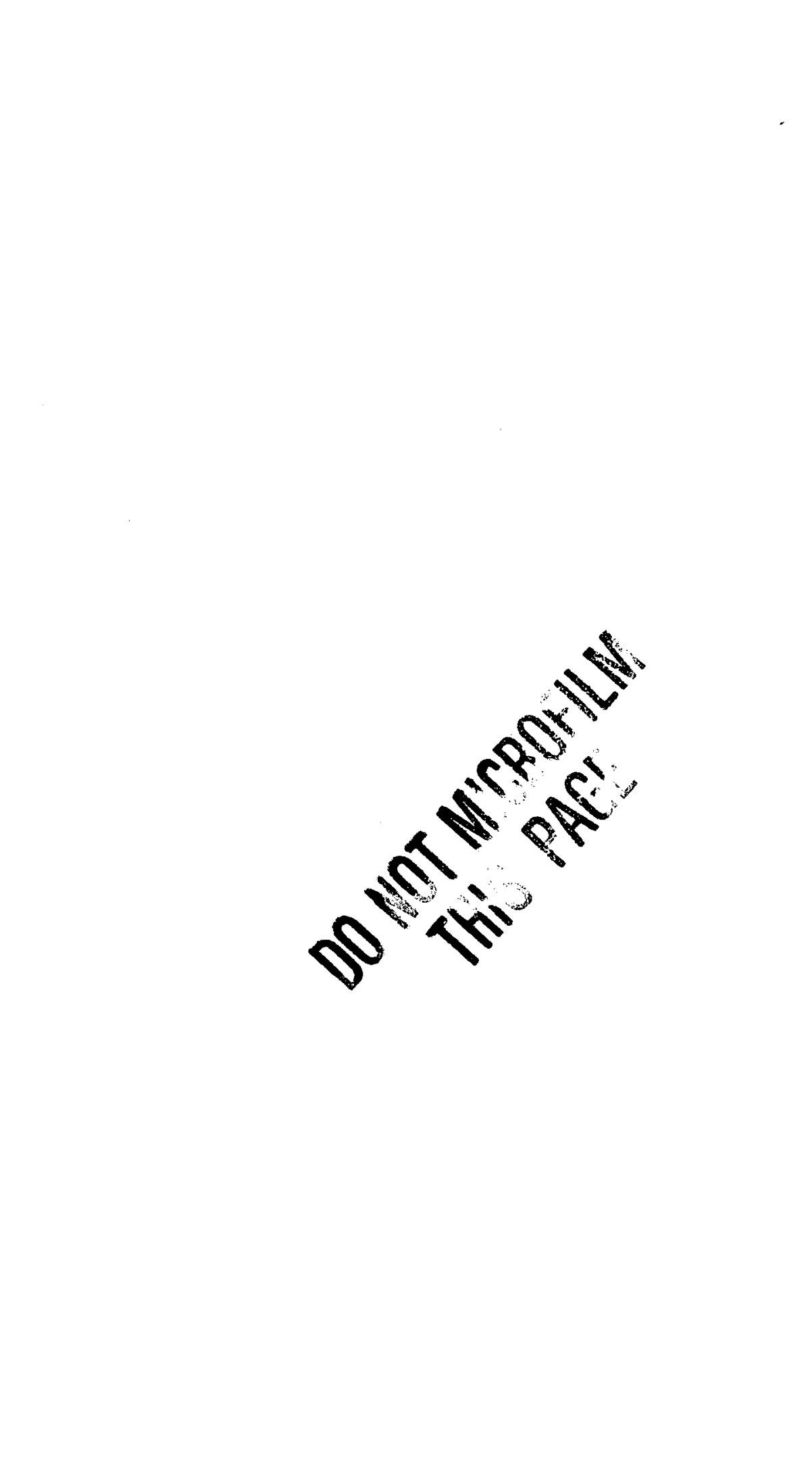
CHAPTER 14

INITIAL TEST PROGRAMS

The criteria identified in this chapter address the initial and preoperational testing of systems, structures, and components important to safety at nuclear reactor plant facilities.

\section{1 specific Information to be Included in Preliminary safety Analysis Reports}

This section in an SAR should describe the major phases of the initial test program and the overall test objectives and general prerequisites for each major phase. In addition, it should describe how the initial test program will be applied and the organizations that will participate in the development and execution of the test program. No specific NRC criteria are identified for this section.

14.2 INITIAL PLANT TEST PROGRAM - FINAL SAFETY ANALYSIS REPORT

14.2.1 Code of Federal Regulations

A. 10 CFR 30.53, "Tests."

B. 10 CFR 50.34, "Contents of Applications: Technical Information," paragraph (b) (6)(iii),. "Plans for Preoperational Testing and Initial operations."

C. 10 CFR 50, Appendix B, "Quality Assurance Criteria for Nuclear Power Plants and Fuel Processing Plants," section XI, "Test Control."

D. 10 CFR 50, Appendix J, "Primary Reactor Containment Leakage Testing for Water-cooled Power Reactors," Section III.A.4, "Preoperational Leakage Rate Tests (Type A Test)."

14.2.2 USNRC Regulatory Guides, SRP Branch Technical Positions and Appendices

A. Regulatory Guide 1.18, "Structural Acceptance Test for concrete Primary "Reactor containments." (This regulatory guide was withdrawn and 'superseded by Regulatory Guide 1.136, "Materials, Construction, and Testing of Concrete Containments.") 
B. Regulatory Guide 1.20, "Comprehensive Vibration Assessment Program for Reactor Internals During Preoperational and Initial startup Testing."

C. Regulatory Guide 1.30, "Quality Assurance Requirements for the Installation, Inspection, and Testing of Instrumentation and Electric Equipment."

D. Regulatory Guide 1.37, "Quality Assurance Requirements for cleaning of Fluid systems and Associated Components of Water-Cooled Nuclear Power Plants."

E. Regulatory Guide 1.41, "Preoperational Testing of Redundant onsite Electric Power systems to Verify Proper Load Group Assignments."

F. Regulatory Guide 1.52 "Design, Testing, and Maintenance Criteria for Post-Accident Engineered-Safety-Feature Atmosphere cleanup system Air Filtration and Adsorption Units of Light-Water-Cooled Nuclear Power Plants."

G. Regulatory Guide. 1.56, "Maintenance of Water Purity in Boiling Water Reactors."

H. Regulatory Guide 1.68, "Initial Test Programs for Water-Cooled Nuclear Power Plants."

I. Regulatory Guide 1.68.1, "Preoperational and Initial startup Testing of Feedwater and condensate systems for Boiling water Reactor Power Plants."

J. Regulatory Guide 1.68.2, "Initial startup Test Program to Demonstrate Remote Shutdown Capability for WaterCooled Nuclear Power Plants."

K. Regulatory Guide 1.68 .3 , "Preoperational Testing of Instrument and Control Air Systems." (Supersedes Regulatory Guide 1.80, "Preoperational Testing of Instrument Air systems.")

L. Regulatory Guide 1.72, "Spray Pond Piping Made From Fiberglass-Reinforced Thermosetting Resin."

M. Regulatory Guide 1.79, "Preoperational Testing of Emergency Core Cooling Systems for Pressurized Water Reactors."

N. Regulatory Guide 1.95, "Protection of Nuclear Power Plant Control Room operators Against an Accidental Chlorine Release."

0. Regulatory Guide 1.108, "Periodic Testing of Diesel Generator Units Used as Onsite Electric Power Systems at Nuclear Power Plants." 
P. Regulatory Guide 1.116, "Quality Assurance Requirements for Installation, Inspection, and Testing of Mechanical Equipment and Systems."

Q. Regulatory Guide 1.128, "Installation Design and Installation of Large Lead storage Batteries for Nuclear Power Plants."

R. Regulatory Guide 1.136, "Materials, Construction, and Testing of concrete containments."

Heat Removal."

S. Regulatory Guide 1.139, "Guidance for Residual

T. Regulatory Guide 1.140, "Design, Testing, and Maintenance Criteria for Normal Ventilation Exhaust System Air Filtration and Adsorption Units of Light-Water-Cooled Nuclear Power Plants."

\subsubsection{Codes and standards}

A. ANSI N45.2.1-1973, "Cleaning of Fluid Systems and Associated Components for Nuclear Power Plants." (This standard was withdrawn November 21, 1985 and incorporated into ANSI/ASME NQA-2-1986, "Quality Assurance Requirements for Nuclear Power Plants.")

B. ANSI N45.2.8-1975, "supplementary Quality Assurance Requirements for Installation, Inspection, and Testing of Mechanical Equipment and systems for the construction Phase of Nuclear Power Plants." (This standard was withdrawn April 7, 1986 and incorporated into ANSI/ASME NQA-2-1986, "Quality Assurance Requirements for Nuclear Power Plants.")

C. ANSI N510-1975, "Testing of Nuclear Air cleaning Systems." (This standard was revised and issued as ANSI/ASME N510-1980, "Testing of Nuclear Air Cleaning Systems.")

D. ANSI/ACI 349-1976, "Code Requirements for Nuclear Safety-Related Concrete structures." (This standard was revised and issued as ANSI/ACI 349-1980, "Code Requirements for Nuclear Safety-Related concrete structures," and ACI 349R-80, Commentary.")

E. ANSI/ASME N45.2.5-1978, "Supplementary Quality Assurance Requirements for Installation, Inspection, and Testing of Structural Concrete, Structural steel, soils, and Foundations During the Construction Phase of Nuclear Power Plants." (This standard was withdrawn April 7, 1986 and incorporated into 
ANSI/ASME NQA-2-1986, "Quality Assurance Requirements for Nuclear Power Plants.")

F. ANSI/ASME N509-1976, "Nuclear Power Plant Air Cleaning Units and Components." (This standard was revised and issued as ANSI/ASME N509-1989, "Nuclear Power Plant Air Cleaning Units and Components.")

G. ASME Boiler and Pressure Vessel Code.

1. Section III, Division 1, "Code Cases Nuclear Components," Code Case N-155-1 (1792-1), "Fiberglass Reinforced Thermosetting Resin Pipe." (This code case was revised and redesignated $\mathrm{N}-155-2$.)

2. Section III, Division 2 (ACI 359-1980), "Code for Concrete Reactor Vessels and Containments."

3. Section XI, "Rules for Inservice Inspection of Nuclear Power Plant Components." of Activated Carbon."

H. ASTM D2854-83, "Test Method for Apparent Density

I. ASTM D2862-82, "Test Method for Particle Size Distribution of Granulated Activated Carbon."

J. IEEE 336-1971, "IEEE standard Installation, Inspection, and Testing Requirements for Instrumentation and Electric Equipment During the Construction of Nuclear Power Generating stations." (This standard was revised and issued as ANSI/IEEE 336-1985, "IEEE Standard Installation, Inspection, and Testing Requirements for Power, Instrumentation, and Control Equipment at Nuclear Facilities.")

K. IEEE 338-1977(R1984), "IEEE standard Criteria for the Periodic Testing of Nuclear Power Generating station safety systems."

L. IEEE 484-1975, "IEEE Recommended Practice for Installation Design and Installation of Large Lead storage Batteries for Generating stations and substations." (This standard was revised and issued as ANSI/IEEE 484-1987, "IEEE Recommended Practice for Installation Design and Installation of Large Lead Storage Batteries for Generating stations and Substations.")

M. MIL-F-51068, "Filter, Particulate, High-Efficiency, Fire-Resistant.

N. MIL-STD-282, "Filter Units, Protective clothing, Gas-Mask Components and Related Products: Performance-Test Methods." 
o. RDT M 16-1T, "Gas-Phase Adsorbents for Trapping Radioactive Iodine and Iodine Compounds," October 1973. (This standard was revised and issued as NE M 16-1T, "Gas-Phase Adsorbents for Trapping Radioactive Iodine and Iodine compounds," December 1977.)

\subsubsection{Supplemental Information}

1987.

A. NUREG-0800, USNRC "Standard Review Plan," June

1. SRP 14.2, "Initial Plant Test Program - Final Safety Analysis Report."

B. NUREG-0737, "clarification of TMI Action Plan Requirements," USNRC, November 1980.

C. NUREG-0694, "TMI-Related Requirements for New Operation Licensees," USNRC, June 1980.

D. NUREG-0660, "NRC Action Plan Developed as a Result of the TMI-2 Accident," USNRC, Vol, 1, May 1980 and Vol. 1, Rev. 1 , August 1980.

E. NUREG/CR-3424, "Equipment Qualification Research Test Program and Failure Analysis of elass 1E Solenoid Valves," USNRC, November 1983.

F. ERDA 76-21, "Nuclear" Air "Cleaning Handbook," ORNL, C.A. Burchsted, J.E. Kahn, and A.B. FullermMarch 31, 1986.

G. ORNL-NSIC-26, "Testing Ofy Containment systems Used With Light-Water-Cooled Power Reactors, "oak Ridge National Laboratory, Frank C. Zapp, August 1968. 


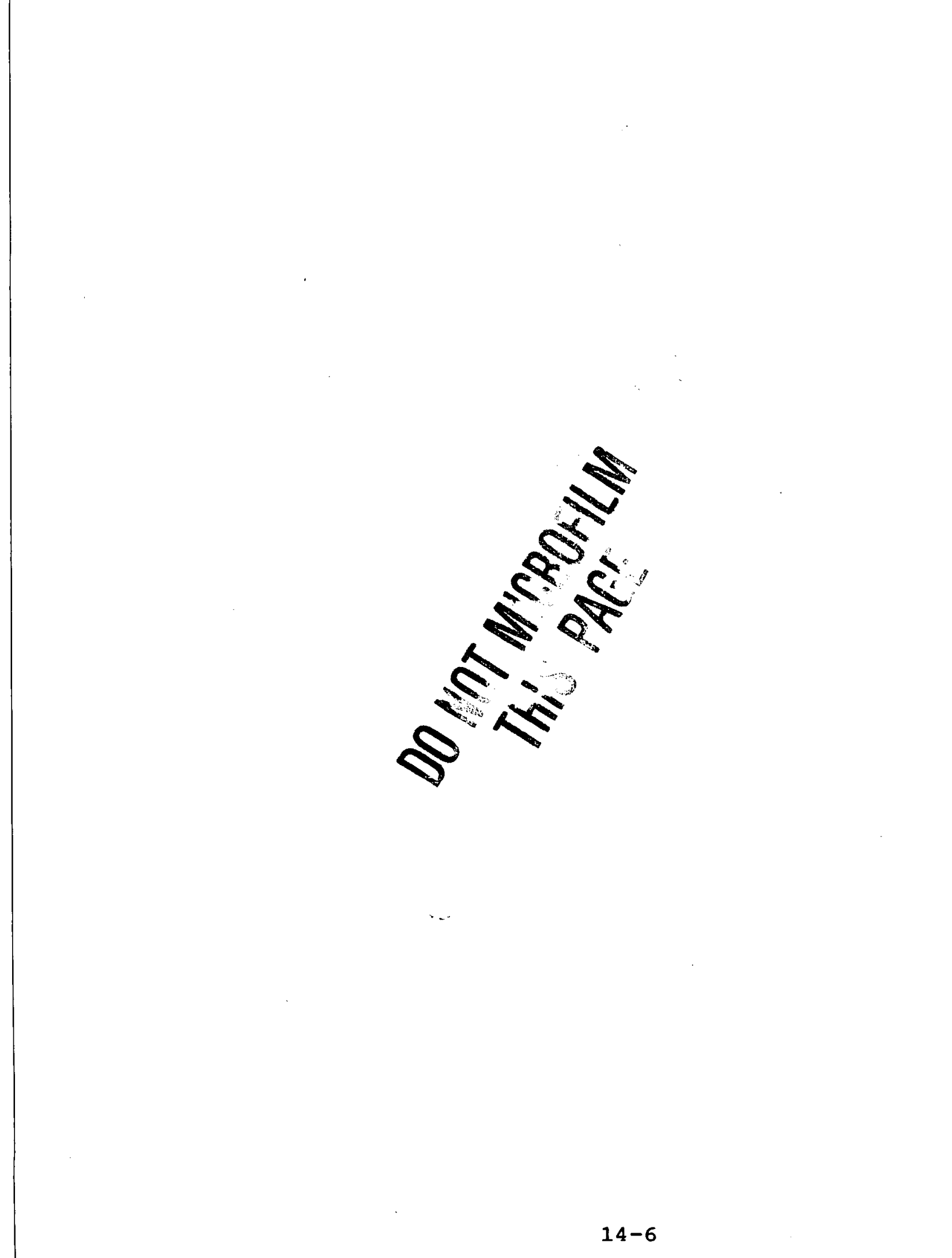

$14-6$

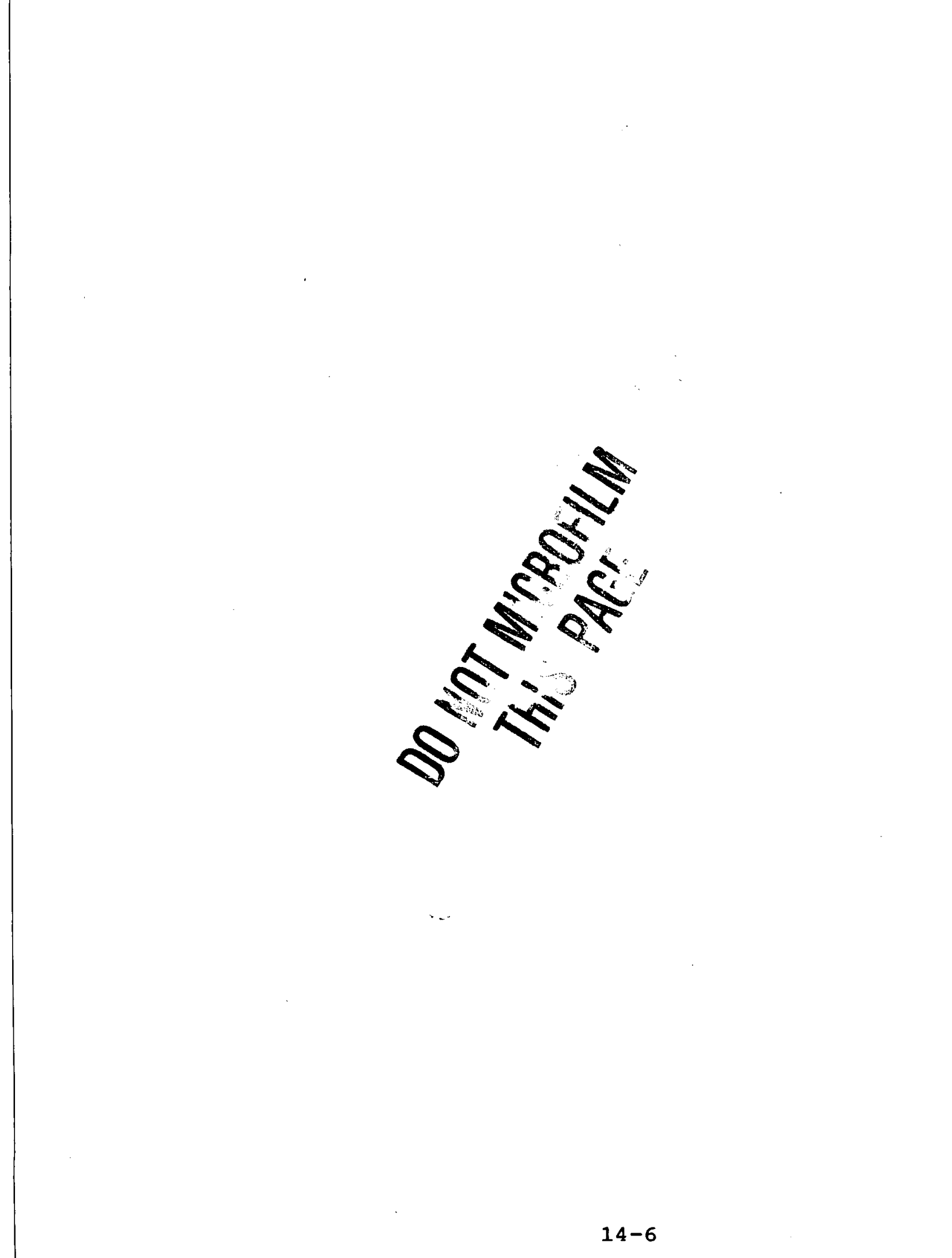

(

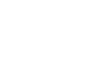
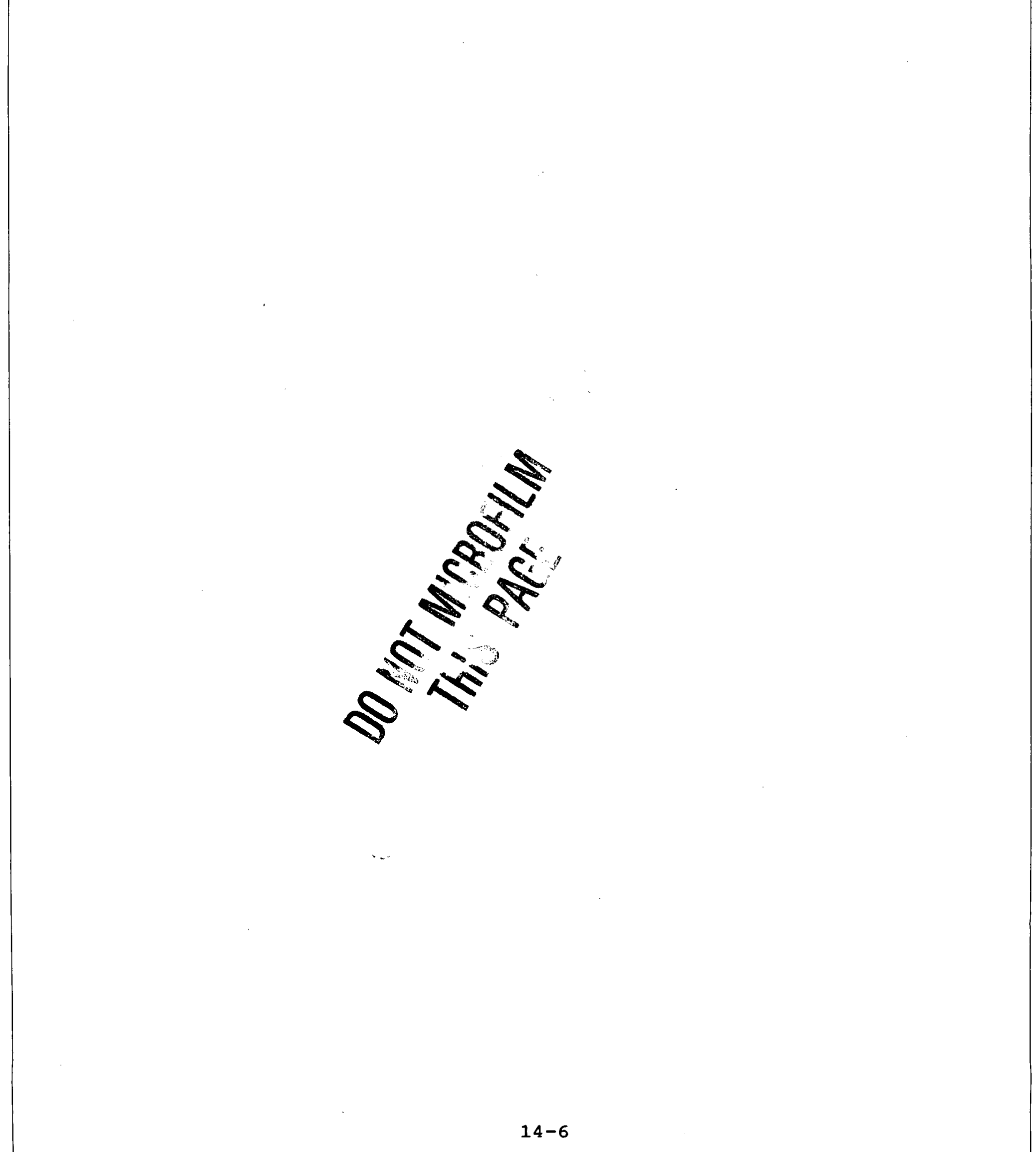

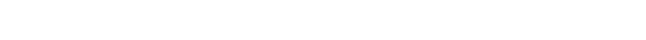




\section{ACCIDENT ANALYSES}

The criteria identified in this chapter are for representative initiating events that result in the unplanned transients that are tabulated in Chapter 15 of Regulatory Guide 1.70 and whose analysis should be included in an SAR.

\subsection{INCREASE IN HEAT REMOVAL BY THE SECONDARY SYSTEM}

This section identifies criteria for initiating events that involve decrease in feedwater temperature, increase in feedwater flow, increase in steam flow, inadvertent opening of steam generator relief or safety valve, and steam system piping failures.

\subsubsection{Code of Federal Regulations} Information."

A. 10 CFR 50.34, "Contents of Applications; Technical

B. 10 CFR 50, Appendix A, "General Design Criteria for Nuclear Power Plants."

1. GDC 10, "Reactor Design."

2. GDC 15, "Reactor Coolant System Design."

3. GDC 26, "Reactivity Control system Redundancy

and Capability."

Capability."

4. GDC 27, "Combined Reactivity Control systems

5. GDC 28, "Reactivity Limits."

6. GDC 31, "Fracture Prevention of Reactor Coolant Pressure Boundary."

7. GDC 35, "Emergency core cooling."

C. 10 CFR 100.11, "Determination of Exclusion Area, Low Population Zone, and Population Center Distance." 
15.1.2 USNRC Regulatory Guides, SRP Branch Technical Positions and Appendices

A. Regulatory Guide 1.4, "Assumptions Used for Evaluating the Potential Radiological Consequences of a Loss-ofCoolant Accident for Pressurized Water Reactors." (The method of calculating $X / Q$ values in this guide is superseded by the method presented in Regulatory Guide 1.145, "Atmospheric Dispersion Models for Potential Accident Consequence Assessments at Nuclear Power Plants.")

B. Regulatory Guide 1.53, "Application of the single-Failure Criterion to Nuclear Power Plant Protection systems."

C. Regulatory Guide 1.145, "Atmosphere Dispersion Models for Potential Accident Consequence Assessments at Nuclear Power Plants."

D. SRP 3.6.1, Branch Technical Position ASB 3-1, "Protection Against Postulated Piping Failures in Fluid systems outside Containment."

E. SRP 3.6.2, Branch Technical Position MEB 3-1, "Postulated Rupture Locations in Fluid System Piping Inside and outside Containment."

F. SRP 15.1.5, Appendix A, "Radiological Consequences of Main steam Line Failures Outside Containment of a PWR."

\subsection{3 codes and standards}

A. ASME Boiler and Pressure Vessel Code, "Rules for Construction of Nuclear Power Plant Components," Section III, Division 1, Article NB-7000, "Protection Against Overpressure."

B. IEEE 379-1972, "IEEE Trial-Use Guide for the Application of the single-Failure Criterion to Nuclear Power Generating station Class 1E systems." (This standard was revised and issued as IEEE 379-1988, "IEEE standard Application of the Single-Failure Criterion to Nuclear Power Generating station class 1E systems.")

\subsubsection{Supplemental Information}

1987.

A. NUREG-0800, USNRC "Standard Review Plan," June

ture."

1. SRP 15.1.1, "Decrease in Feedwater Tempera- 
2. SRP 15.1.2, "Increase in Feedwater Flow."

3. SRP 15.1.3, "Increase in steam Flow.".

4. SRP 15.1.4, "Inadvertent Opening of a steam Generator Relief or Safety Valve."

5. SRP 15.1.5, "Steam System Piping Failures Inside and Outside of containment (PWR)."

B. NUREG-0718, "Licensing Requirements for Pending Applications for Construction Permits and Manufacturing License," USNRC, March 1981.

c. NUREG-0737, "Clarification of TMI Action Plan Requirements," USNRC, November 1980.

D. NUREG-0694, "TMI-Related Requirements for New operation Licenses," USNRC, June 1980 .

E. NUREG-0224, "Final Report on Reactor Vessel Pressure Transient Protection for Pressurized Water Reactors," USNRC, September 1978 .

F. NUREG/CR-2260, "Technical Basis for Regulatory Guide 1.145, Atmosphere Dispersion Models for Potential Accident Consequence Assessments at Nuclear Power Plants," W.G. Snell and R.W. Jubach, NUS Corp., October 1981 .

\subsection{DECREASE IN HEAT REMOVAL BY THE SECONDARY SYSTEM}

This section identifies criteria for initiating events that involve loss of external load, turbine trip, loss of condenser vacuum, closure of BWR main steam isolation valve, steam pressure regulator failure, loss of nonemergency ac power to the station auxiliaries, loss of normal feedwater flow, and feedwater system pipe breaks.

\subsubsection{Code of Federal Regulations}

Information."

A. 10 CFR 50.34, "Contents of Applications; Technical

B. 10 CFR 50, Appendix A, "General Design Criteria for Nuclear Power Plants."

1. GDC 10, "Reactor Design."

2. GDC 15, "Reactor Coolant System Design." 
and Capability." GDC 26, "Reactivity Control System Redundancy Capability."

4. GDC 27, "Combined Reactivity Control Systems 5. GDC 28, "Reactivity Limits."

6. GDC 31, "Fracture Prevention of Reactor Coolant Pressure Boundary."

7. GDC 35, "Emergency Core Cooling."

C. 10 CFR 100.11, "Determination of Exclusion Area, Low Population Zone, and Population Center Distance."

\subsubsection{USNRC Regulatory Guides, SRP Branch Technical Positions and Appendices}

A. Regulatory Guide 1.53, "Application of the Single-Failure Criterion to Nuclear Power Plant Protection Systems."

B. Regulatory Guide 1.105, "Instrument setpoints for Safety-Related Systems."

c. Regulatory Guide 1.145, "Atmospheric Dispersion Models for Potential Accident Consequence Assessments at Nuclear Power Plants."

D. SRP 3.6.1, Branch Technical Position ASB 3-1, "Protection Against Postulated Piping Failures in Fluid Systems outside Containment."

E. SRP 3.6.2, Branch Technical Position MEB 3-1, "Postulated Rupture Locations in Fluid System Piping Inside and outside Containment."

\subsubsection{Codes and standards}

A. ASME Boiler and Pressure Vessel Code, "Rules for Construction of Nuclear Power Plant components," Section III, Division 1, Article NB-7000, "Protection Against Overpressure."

B. ANSI/ISA-S67.04-1982, "Setpoints for Nuclear Safety-Related Instrumentation Used in Nuclear Power Plants." 
C. IEEE 379-1972, "IEEE Trial-Use Guide for the Application of the Single-Failure Criterion to Nuclear Power Generating station class 1E systems." (This standard was revised and issued as IEEE 379-1988, "IEEE Standard Application of the Single-Failure criterion to Nuclear Power Generating station class 1E systems.")

\subsubsection{Supplemental Information}

1987.

A. NUREG-0800, USNRC "Standard Review Plan," June

1. SRP 15.2.1, "Loss of External Load."

2. SRP 15.2.2, "Turbine Trip."

3. SRP 15.2.3, "Loss of Condenser Vacuum."

Valve (BWR)." 4. SRP 15.2.4, "Closure of Main steam Isolation (closed)."

5. SRP 15.2.5, "Steam Pressure Regulator Failure the station Auxiliaries."

6. SRP 15.2.6, "Loss of Nonemergency AC Power to 7. SRP 15.2.7, "Loss of Normal Feedwater Flow."

8. SRP 15.2.8, "Feedwater System Pipe Breaks Inside and outside Containment (PWR)."

B. NUREG-0718, "Licensing Requirements for Pending Applications for Construction Permits and Manufacturing License," USNRC, March 1981.

D. NUREG/CR-2260, "Technical Basis for Regulatory Guide 1.145, Atmosphere Dispersion Models for Potential Accident Consequence Assessments at Nuclear Power Plants, W.G. Snell and R.W. Jubach, NUS Corp., October 1981.

E. IE Bulletin 79-13, Rev. 2, "Cracking in Feedwater system Piping."

Power."

F. IE Information Notice 84-76, "Loss of All AC 
This section identifies criteria for initiating events that involve loss of forced reactor coolant flow, trip of pump motor and flow controller malfunctions, and reactor coolant pump rotor seizure and pump shaft break.

\subsubsection{Code of Federal Regulations}

Information."

A. 10 CFR 50.34, "Contents of Applications; Technical

B. 10 CFR 50, Appendix A, "General Design Criteria for Nuclear Power Plants."

1. GDC 10, "Reactor Design."

2. GDC 15, "Reactor Coolant System Design."

and capability."

3. GDC 26, "Reactivity Control System Redundancy Capability."

4. GDC 27, "Combined Reactivity Control Systems

5. GDC 28, "Reactivity Limits."

6. GDC 31, "Fracture Prevention of Reactor Coolant Pressure Boundary."

C. 10 CFR 100.11, "Determination of Exclusion Area, Low Population Zone, and Population Center Distance."

15.3.2 USNRC Regulatory Guides, SRP Branch Technical Positions and Appendices

A. Regulatory Guide 1.145, "Atmospheric Dispersion Models for Potential Accident Consequence Assessments at Nuclear Power Plants."

\subsection{3 codes and standards}

A. ASME Boiler and Pressure Vessel Code, "Rules for Construction of Nuclear Power Plant Components," Section III, Division 1, Article NB-7000, "Protection Against Overpressure." 
15.3.4 supplemental Information

1987.

A. NUREG-0800, USNRC "Standard Review Plan," June

1. SRP 15.3.1, "Loss of Forced Reactor coolant Flow Including Trip of Pump Motor."

zure."

2. SRP 15.3.2, "Flow Controller Malfunctions."

3. SRP 15.3.3, "Reactor Coolant Pump Rotor Sei-

Break."

SRP 15.3.4, "Reactor Coolant Pump shaft

B. NUREG-0718, "Licensing Requirements for Pending Applications for Construction Permits and Manufacturing License," USNRC, March 1981.

C. NUREG-0737, "Clarification of TMI Action Plan Requirements," USNRC, November 1980.

D. NUREG-0158, "Staff Discussion of Twelve Additional Technical Issues Raised by Responses to November 3, 1976 Memorandum from the Director, NRR to NRR Staff," USNRC, December 1976.

E. NUREG-0138, "Staff Discussion of Fifteen Technical Issues Listed in Attachment to November 3, 1976, Memorandum from Director NRR to NRR Staff," USNRC, November 1976.

F. NUREG/CR-2260, "Technical Basis for Regulatory Guide 1.145, Atmosphere Dispersion Models for Potential Accident Consequence Assessments at Nuclear Power Plants," W.G. Snell and R.W. Jubach, NUS Corp., October 1981 .

G. IE Information Notice 85-03, "Separation of Primary Reactor Coolant Pump Shaft and Impeller."

\subsection{REACTIVITY AND POWER DISTRIBUTION ANOMALIES}

This section identifies criteria for initiating events that involve uncontrolled control rod withdrawal from a subcritical or low power startup condition, uncontrolled control rod withdrawal at power, control rod misoperation, startup of an inactive primary or recirculation loop at an incorrect temperature, flow controller malfunction, decrease in chemical poisons dissolved in the moderator, inadvertent loading and operation of a fuel assembly in an improper position, and control rod ejection 
and drop accidents.

15.4.1 Code of Federal Regulations Information."

A. 10 CFR 50.34, "Control of Applications; Technical

B. 10 CFR 50, Appendix A, "General Design Criteria for Nuclear Power Plants."

1. GDC 10, "Reactor Design."

2. GDC 13, "Instrumentation and control."

3. GDC 15, "Reactor Coolant System Design."

4. GDC 20, "Protection System Functions."

5. GDC 25, "Protection System Requirements for Reactivity Control Malfunctions."

and Capability."

6. GDC 26, "Reactivity Control System Redundancy

7. GDC 28, "Reactivity Limits."

c. 10 CFR 100.11, "Determination of Exclusion Area, Low Population Zone, and Population Center Distance."

15.4.2 UsNRC Regulatory Guides; SRP Branch Technical Positions and Appendices

A. Regulatory Guide 1.53, "Application of the single-Failure Criterion to Nuclear Power Plant Protection systems."

B. Regulatory Guide 1.77, "Assumptions Used for Evaluating a Control Rod Ejection Accident for Pressurized Water Reactors." (The method of calculating $X / Q$ values in this guide is superseded by the method presented in Regulatory Guide 1.145, "Atmospheric Dispersion Models for Potential Accident Consequences Assessments at Nuclear Power Plants.")

safety-Related systems."

C. Regulatory Guide 1.105, "Instrument setpoints for

D. Regulatory Guide. 1.145, "Atmospheric Dispersion Models for Potential Accident Consequence Assessments at Nuclear Power Plants."

E. SRP 15.4.8, Appendix A, "Radiological Consequences of a Control Rod Ejection Accident (PWR)." 
F. SRP 15.4.9, Appendix A, "Radiological Consequences of a Control Rod Drop Accident (BWR)."

15.4.3 codes and standards

A. ANSI/ISA-S67.04-1982, "setpoints for Nuclear Safety-Related Instrumentation Used in Nuclear Power Plants."

B. ASME Boiler and Pressure Vessel Code, "Rules for Construction of Nuclear Power Plant Components," section III, Division 1, Article NB-7000, "Protection Against Overpressure."

C. IEEE 379-1972, "IEEE Trial-Use Guide for the Application of the single-Failure Criterion to Nuclear Power Generating station Class 1E systems." (This standard was revised and issued as IEEE 379-1988, "IEEE standard Application of the Single-Failure criterion to Nuclear Power Generating station class 1E systems.")

\subsubsection{Supplemental Information}

1987.

A. NUREG-0800, USNRC "Standard Review Plan," June

1. SRP 15.4.1, "Uncontrolled Control Rod Assembly withdrawal from a subcritical or Low Power startup Condition."

2. SRP 15.4.2, "Uncontrolled control Rod Assembly withdrawal at Power.".

3. SRP 15.4.3, "Control Rod Misoperation (System Malfunction or operator Error)."

4. SRP 15.4.4, "Startup of an Inactive Loop or Recirculation Loop at an Incorrect Temperature."

5. SRP 15.4.5, Flow Controller Malfunction Causing an Increase in BWR Core Flow Rate."

6. SRP 15.4.6, "Chemical and Volume Control System Malfunction That Results in a Decrease in Boron Concentration in the Reactor coolant (PWR)."

7. SRP 15.4.7, "Inadvertent Loading and Operation of a Fuel Assembly in an Improper Position."!

dents (PWR)." 8. SRP 15.4.8, "spectrum of Rod Ejection Acci- 
(BWR) . "

9. SRP 15.4.9," "Spectrum of Rod Drop Accidents

B. NUREG-0696, "Functional Criteria for Emergency Response Facilities," USNRC, February 1981.

c. NUREG-0737, "Clarification of TMI Action Plan Requirements," USNRC, November 1980.

D. NUREG-0660, "NRC Action Plan Developed as a Result of the TMI-2 Accident," USNRC, Vol. 1, May 1980 and Vol. 1, Rev. 1 , August 1980 .

E. NUREG-0224, "Final Report on Reactor Vessel Pressure Transient Protection for Pressurized Water Reactors," USNRC, September 1978 .

\subsection{INCREASE IN REACTOR COOLANT INVENTORY}

This section identifies criteria for initiating events that involve inadvertent operation of emergency core cooling systems and malfunction of the chemical and volume control system that increases reactor coolant inventory.

\subsubsection{Code of Federal Regulations}

Information."

A. 10 CFR 50.34, "Contents of Applications; Technical

B. 10 CFR 50.61 "Fracture Toughness Requirements for Protection Against Pressurized Thermal Shock Events."

C. 10 CFR 50, Appendix A, "General Design Criteria for Nuclear Power Plants."

1. GDC 10, "Reactor Design."

2. GDC 15, "Reactor Coolant System Design."

3. GDC 26, "Reactivity Control System Redundancy

and Capability."

\subsubsection{USNRC Regulatory Guides, SRP Branch Technical Positions and Appendices}

A. Regulatory Guide 1.53, "Application of the Single-Failure Criterion to Nuclear Power Plant Protection systems."

B. Regulatory Guide 1.105, "Instrument Setpoints for Safety-Related systems." 
c. Regulatory Guide 1.154 , "Format and Content of Plant-Specific Pressurized Thermal Shock Safety Analysis Reports for Pressurized Water Reactors."

\subsubsection{Codes and standards}

A. ANSI/ISA-S67.04-1982, "setpoints for Nuclear Safety-Related Instrumentation Used in Nuclear Power Plants."

B. ASME Boiler and Pressure Vessel Code, "Rules for Construction of Nuclear Power plant Components," section III, Division 1, Article NB-7000, "Protection Against Overpressure."

C. IEEE 379-1972, "IEEE Trial-Use Guide for the Application of the Single-Failure Criterion to Nuclear Power Generating station class 1E Systems." (This standard was revised and issued as IEEE 379-1988, "IEEE standard Application of the Single-Failure Criterion to Nuclear Power Generating station Class 1E systems.")

\subsection{4 supplemental Information}

1987.

A. NUREG-0800, USNRC "Standard Review Plan," June

1. SRP 15.5.1, "Inadvertent Operation of ECCS That Increases Reactor Coolant Inventory."

2. SRP 15.5.2, "Chemical and Volume control System Malfunction That Increases Reactor Coolant Inventory."

B. NUREG-0744, Rev. 1, "Resolution of Task A-11 Reactor Vessel Materials Toughness Safety Issue," Vols. 1 and 2 , USNRC, October 1982 .

C. NUREG-0660, "NRC Action Plan Developed as a Result of the TMI-2 Accident," USNRC, Vol. 1, May 1980 and Vol. 1, Rev. 1 , August 1980 .

D. NUREG-0224, "Final Report on Reactor Vessel Pressure Transient Protection for Pressurized Water Reactors," USNRC, September 1978 .

\subsection{DECREASE IN REACTOR COOLANT INVENTORY}

This section identifies criteria for initiating events that involve inadvertent opening of pressure relief valves, failure of small lines carrying primary coolant outside containment, 
steam generator tube failure, main steam line failure outside containment, and loss of coolant accidents resulting from a spectrum of postulated piping breaks within the reactor coolant pressure boundary.

\subsubsection{Code of Federal Regulations}

Information."

A. 10 CFR 50.34, "Contents of Applications; Technical

B. 10 CFR 50.44, "Standards for Combustible Gas Control System in Light-Water-Cooled Power Reactors."

c. 10 CFR 50.46, "Acceptance Criteria for Emergency Core Cooling systems for Light-Water Nuclear Power Reactors."

D. 10 CFR 50.61, "Fracture Toughness Requirements for Protection Against Pressurized Thermal Shock Events."

E. 10 CFR 50, Appendix A, "General Design Criteria for Nuclear Power Plants."

1. GDC 10, "Reactor Design."

2. GDC 15, "Reactor Coolant System Design."

and Capability."

3. GDC 26, "Reactivity Control System Redundancy

4. GDC 35, "Emergency Core Cooling."

5. GDC 41, "Containment Atmosphere Cleanup."

Penetrating containment."

6. GDC 55, "Reactor Coolant Pressure Boundary

F. 10 CFR 50, Appendix K, "ECCS Evaluation Models."

G. 10 CFR 100.11, "Determination of Exclusion Area, Low Population Zone, and Population Center Distance."

\subsubsection{USNRC Regulatory Guides, SRP Branch Technical Positions} and Appendices

The method of calculating $X / Q$ values in Regulatory Guides $1.3,1.4$, and 1.5 is superseded by the method presented in Regulatory Guide 1.145, "Atmospheric Dispersion Models for Potential Accident Consequence Assessments at Nuclear Power Plants."

A. Regulatory Guide 1.3, "Assumptions Used for Evaluating the Potential Radiological Consequences of a Loss-ofcoolant Accident for Boiling water Reactors." 
B. Regulatory Guide 1.4, "Assumptions Used for Evaluating the Potential Radiological Consequences of a Loss-ofCoolant Accident for Pressurized Water Reactors."

c. Regulatory Guide 1.5, "Assumptions Used for Evaluating the Potential Radiological Consequences of a steam Line Break Accident for Boiling Water Reactors."

D. Regulatory Guide 1.7, "Control of Combustible Gas concentrations in Containment Following a Loss-of-Coolant Accident."

E. Regulatory Guide 1.11, "Instrument Lines Penetrating Primary Reactor Containment."

F. Regulatory Guide 1.53, "Application of the single-Failure Criterion to Nuclear Power Plant. Protection systems."

G. Regulatory Guide 1.105, "Instrument setpoints for Safety-Related systems."

H. Regulatory Guide 1.145, "Atmospheric Dispersion Models for Potential Accident Consequence Assessments at Nuclear Power Plants."

I. Regulatory Guide 1.154, "Format and Content of Plant-Specific Pressurized Thermal Shock Safety Analysis Reports for Pressurized water Reactors."

J. SRP 15.6.5, Appendix A, "Radiological Consequences of a Design Basis Loss-of-Coolant Accident Including Containment Leakage Contribution.

K. SRP 15.6.5, Appendix B, "Radiological Consequences of a Design Basis Loss-of-Coolant Accident: Leakage - from Engineered-Safety-Feature Components Outside Containment."

L. SRP 15.6.5, Appendix D, "Radiological Consequences of a Design Basis Loss-of-Coolant Accident: Leakage from Main steam Isolation Valve Leakage Control System (BWR)."

\subsubsection{Codes and standards}

A. ANSI/ISA-S67.04-1982, "setpoints for Nuclear Safety-Related Instrumentation Used in Nuclear Power Plants."

B. ASME Boiler and Pressure Vessel Code, "Rules for Construction of Nuclear Power Plant Components," Section III, Division 1, Article NB-7000, "Protection Against Overpressure." 
C. IEEE 379-1972, "IEEE Trial-Use Guide for the Application of the Single-Failure Criterion to Nuclear Power Generating station class 1E Systems." (This standard was revised and issued as IEEE 379-1988, "IEEE Standard Application of the Single-Failure Criterion to Nuclear Power Generating station class $1 \mathrm{E}$ systems.")

\subsubsection{Supplemental Information}

1987 .

A. NUREG-0800, USNRC "Standard Review Plan," June

1. SRP 15.6.1, "Inadvertent Opening of a PWR Pressurizer Pressure Relief Valve or a BWR Pressure Relief Valve."

2. SRP 15.6.2, "Radiological Consequences of the Failure of Small Lines Carrying Primary Coolant outside Containment."

3. SRP 15.6.3, "Radiological consequences of Steam Generator Tube Failure (PWR)."

4. SRP 15.6.4, "Radiological Consequences of Main steam Line Failure Outside Containmen't (BWR)."

5. SRP 15.6.5, "Loss-of-Coolant Accidents Resulting from spectrum of Postulated Piping Breaks Within the Reactor Coolant Pressure Boundary."

B. NUREG-0737, "Clarification of TMI Action Plan Requirements," USNRC, November 1980.

C. NUREG-0718, "Licensing Requirements for Pending Applications for Construction Permits and Manufacturing License," USNRC, March 1981.

D. NUREG-0409, "Iodine Behavior in a PWR Cooling System Following a Postulated steam Generator Tube Rupture Accident," USNRC, January 1978.

E. NUREG-0224, "Final Report on Reactor Vessel Pressure Transient Protection for Pressurized Water Reactors," USNRC, September 1978 .

F. NUREG/CR-2260, "Technical Basis for Regulatory Guide 1.145, Atmospheric Dispersion Models for Potential Accident Consequence Assessments at Nuclear Power Plants," W.G. Snell and R.W. Jubach, NUS Corp. October 1981. 
This section identifies criteria for initiating events that involve postulated radioactive releases due to liquidcontaining tank failures, radiological consequences of fuelhandling accidents, and spent fuel cask drop accidents.

\subsubsection{Code of Federal Regulations}

A. 10 CFR 20, Appendix B, "Concentrations in Air and Water Above Background."

Information."

B. 10 CFR 50.34, "Control of Applications; Technical

C. 10 CFR $50.36 \mathrm{a}$, "Technical specifications on Effluents from Nuclear Power Reactors."

D. 10 CFR 50, Appendix A, "General Design Criteria for Nuclear Power Plants."

1. GDC 60, "Control of Releases of Radioactive Materials to the Environment."

2. GDC 61, "Fuel storage and Handling and Radioactivity Control."

E. 10 CFR 100.11, "Determination of Exclusion Area, Low Population Zone, and Population Center Distance."

15.7.2 U8NRC Regulatory Guides, SRP Branch Technical Positions and Appendices

A. Regulatory Guide 1.25, "Assumptions Used for Evaluating the Potential Radiological Consequences of a FuelHandling Accident in the Fuel Handling and storage Facility for Boiling and Pressurized water Reactors." (The method of calculating $X / Q$ values in this guide is superseded by the method presented in Regulatory Guide 1.145, "Atmospheric Dispersion Models for Potential Accident Consequence Assessments at Nuclear Power Plants.")

B. Regulatory Guide 1.145, "Atmospheric Dispersion Models for Potential Accident Consequence Assessments at Nuclear Power Plants."

\subsubsection{Codes and standards}

None. 
15.7.4 Bupplemental Information

1987.

A. NUREG-0800, USNRC "Standard Review Plan," June

1. SRP 15.7.3, "Postulated Radioactive Releases Due to Liquid-Containing Tank Failures."

2. SRP 15.7.4, "Radiological Consequences of Fuel Handling Accidents."

3. SRP 15.7.5, "Spent Fuel Cask Drop Accidents."

B. NUREG-0133, "Preparation of Radiological Effluent Technical Specifications for Nuclear Power Plants," USNRC, October 1978 .

15.8 ANTICIPATED TRANSIENTS WITHOUT SCRAM

15.8.1 Code of Federal Regulations

A. 10 CFR 50.62, "Requirements for Reduction of Risk from Anticipated Transients Without Scram (ATWS) Events for Light-Water-Cooled Nuclear Power Plants."

Nuclear Power Plants."

B. 10 CFR 50, Appendix A, "General Design Criteria for

1. GDC 10, "Reactor Design."

2. GDC 15, "Reactor Coolant System Design."

and Capability."

GDC 26, "Reactivity Control system Redundancy

4. GDC 27, "Combined Reactivity Control Systems

Capability."

5. GDC 29, "Protection Against Anticipated Operational Occurrences."

15.8.2 UBNRC Regulatory Guides, BRP Branch Technical Positions and Appendices

None.

15.8.3 Codes and standards

None. 
15.8.4 supplemental Information

1987.

A. NUREG-0800, USNRC "Standard Review Plan," June

scram."

1. SRP 15.8, "Anticipated Transients without

B. NUREG-0460, Volume 4, "Anticipated Transients Without Scram for Light water Reactors," USNRC, March 1980.

c. WASH 1270, "Technical Report on Anticipated Transients Without scram for Water-Cooled Power Reactors," USAEC, September 1973 .
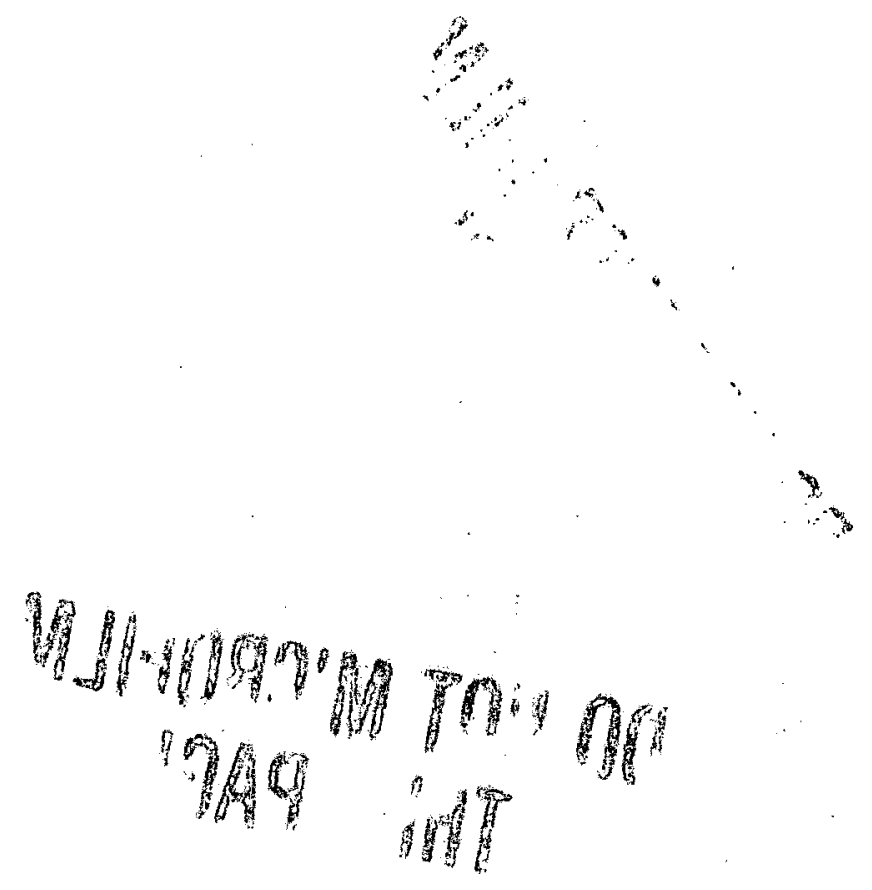

$15-17$ 


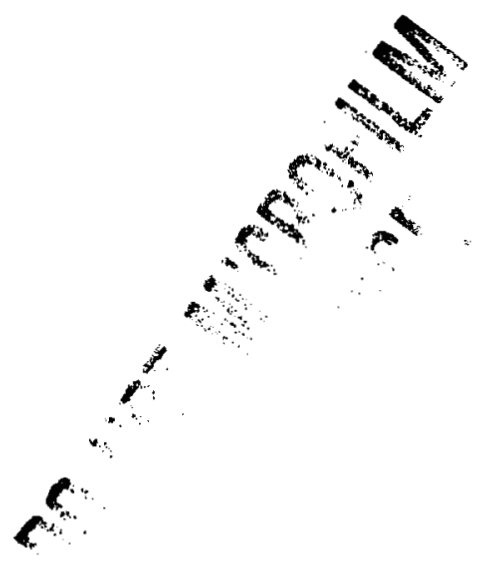

\section{DO MOT M'RROFILM
This PACE}

$15-18$ 
CHAPTER 16

TECHNICAL SPECIFICATIONS

16.1

TECHNICAL BPECIFICATIONS (PRELIMINARY AND FINAL)

Regulatory Guide 1.70 requires the submission of preliminary Technical specifications with the PSAR and proposed final Technical specifications with the FSAR. The criteria identified in this section are for both preliminary and proposed final Technical specifications.

\subsubsection{Code of Federal Regulations}

A. Commission Interim Policy statement, "Technical Specification Improvements for Nuclear Power Reactors," 52 FR 3788 , February 6, 1987.

Information."

B. 10 CFR 50.34, "Contents of Applications, Technical

c. 10 CFR 50.36, "Technical specifications."

D. 10 CFR 50.36a, "Technical specifications on Effluents from Nuclear Power Reactors."

E. 10 CFR 50.54, "Conditions of Licenses."

F. $\quad 10$ CFR 50.73, "Licensee Event Report System."

16.1.2 USNRC Regulatory Guides, SRP Branch Technical Positions and Appendices

A. Regulatory Guide 1.16, "Reporting of operating Information -Appendix A Technical specifications."

B. Regulatory Guide 2.2, "Development of Technical Specifications for Experiments in Research Reactors."

c. Regulatory Guide 4.8, "Environmental Technical Specifications for Nuclear Power Plants."

\subsubsection{CODES AND STANDARDS}

A. ANSI/ANS 15.1-1982, "Development of Technical Specifications for Research Reactors." 
B. ANSI/ANS 58.4-1979, "Criteria for Technical Specifications for Nuclear Power stations."

\subsubsection{SUPPLEMENTAL INFORMATION}

1987.

A. NUREG-0800, USNRC "Standard Review Plan," June

$$
\text { 1. SRP 16.0, "Technical Specifications." }
$$

B. NUREG-0452, Rev. 2, "Standard Technical Specifications for Westinghouse Pressurized Water Reactors," USNRC, June 1978 .

C. NUREG-0212, Rev. 1, "Standard Technical Specifications for Combustion Engineering Pressurized Water Reactors," USNRC, August 1979.

D. NUREG-0123, "standard Technical Specifications for General Electric Boiling Water Reactors," USNRC, August 1979.

E. NUREG-0103, Rev. 3, "Standard Technical Specifications for Babcock and Wilcox Pressurized Water Reactors," USNRC, July 1979. 
CHAPTER 17

QUALITY ABSURANCE

17.1 QUALITY ASSURANCE DURING DESIGN AND CONSTRUCTION

\subsubsection{Code of Federal Regulations}

A. 10 CFR 50.34(a)(7), "Contents of Applications; Technical Information."

B. 10 CFR 50.54, "Conditions of Licenses."

C. 10 CFR 50.55, "Conditions of Construction Permits."

D. $\quad 10$ CFR 50.55a, "Codes and Standards."

E. 10 CFR 50.71, "Maintenance of Records, Making of Reports."

F. 10 CFR 50, Appendix A, "General Design Criteria for Nuclear Power Plants."

G. 10 CFR 50, Appendix B, "Quality Assurance Criteria for Nuclear Power Plants and Fuel Reprocessing Plants."

17.1.2 USNRC Regulatory Guides, SRP Branch Technical Positions and Appendices

A. Regulatory Guide 1.8, "Qualification and Training of Personnel for Nuclear Power Plants."

B. Regulatory Guide 1.26, "Quality Group Classifications, and standards for Water-, steam-, and Radioactive-WasteContaining Components of Nuclear Power. Plants."

C. Regulatory Guide 1.28, "Quality Assurance Program Requirements (Design and Construction)."

cation."

D. Regulatory Guide 1.29, "Seismic Design Classifi-

E. Regulatory Guide 1.30, "Quality Assurance Requirements for the Installation, Inspection, and Testing of Instrumentation and Electric Equipment."

F. Regulatory Guide 1.37, "Quality Assurance Requirements for cleaning of Fluid systems and. Associated Components of Water-Cooled Nuclear Power Plants." 
G. Regulatory Guide 1.38, "Quality Assurance Requirements for Packaging, Shipping, Receiving, Storage, and Handling of Items for Water-Cooled Nuclear Power Plants."

H. Regulatory Guide 1.39, "Housekeeping Requirements for Water-Cooled Nuclear Power Plants."

I. Regulatory Guide 1.54, "Quality Assurance Requirements for Protective Coatings Applied to Water-Cooled Nuclear Power plants."

J. Regulatory Guide 1.58, "Qualification of Nuclear Power Plant Inspection, Examination, and Testing Personnel."

K. Regulatory Guide 1.64, "Quality Assurance Requirements for the Design of Nuclear Power Plants." and Definitions."

L. Regulatory Guide 1.74, "Quality Assurance Terms

M. Regulatory Guide 1.88, "Collection, Storage, and Maintenance of Nuclear Power Plant Quality Assurance Records."

N. Regulatory Guide 1.94, "Quality Assurance Requirements for Installation, Inspection, and Testing of structural Concrete and structural steel During the construction phase of Nuclear Power Plants."

0. Regulatory Guide 1.116, "Quality Assurance Requirements for Installation, Inspection, and Testing of Mechanical Equipment and Systems."

P. Regulatory Guide 1.123, "Quality Assurance Requirements for Control of Procurement of Items and Services for Nuclear Power Plants."

Q. Regulatory Guide 1.143, "Design Guidance for Radioactive. Waste Management systems, structures, and Components Installed in Light-Water-Cooled Nuclear Power Plants."

R. Regulatory Guide 1.144, "Auditing of Quality Assurance Programs for Nuclear Power Plants."

S. Regulatory Guide 1.146, "Qualification of Quality Assurance Program Audit Personnel for Nuclear Power Plants."

T. Regulatory Guide 2.5, "Quality Assurance Program Requirements for Research Reactors."

U. SRP 9.5.1, Branch Technical Position CMEB 9.5-1, "Guidelines for Fire Protection for Nuclear Power Plants." 


\subsection{3 codes and standards}

Standards N45.2, N45.2.6, N45.2.9, N45.2.10, N45.2.13 and N45.2.23 that are specified in NRC criteria and listed below were withdrawn and incorporated into ANSI/ASME NQA-1-1986, "Quality Assurance Program Requirements for Nuclear Facilities." Standards N45.2.1, N45.2.2, N45.2.3, N45.2.5 and N45.2.8 were withdrawn and incorporated into ANSI/ASME NQA-2-1986, "Quality Assurance Requirements for Nuclear Power Plants."

A. ANSI N45.2.2-1972, "Packaging, Shipping, Receiving, storage and Handling of Items for Nuclear Power Plants."

B. ANSI N45.2.3-1973, "Housekeeping During the Construction Phase of Nuclear Power Plants."

C. ANSI N45.2.5-1974, "Supplementary Quality Assurance Requirements for Installation, Inspection, and Testing of structural concrete, structural steel, soils and Foundations During the Construction Phase of Nuclear Power Plants."

D. ANSI N45.2.8-1975, "supplementary Quality Assurance Requirements for Installation, Inspection and Testing of Mechanical Equipment and systems for the construction Phase of Nuclear Power Plants."

E. ANSI N45.2.9-1974, "Requirements for Collection, Storage, and Maintenance of Quality Assurance Records for Nuclear Power Plants."

Definitions."

F. ANSI N45.2.10, "Quality Assurance Terms and

G. ANSI N45.2.11-1974, "Quality Assurance Requirements for the Design of Nuclear Power Plants."

H. ANSI/ANS 3.1-1981, "Selection, Qualification and Training of Personnel for Nuclear Power Plants." (This standard was revised and issued as ANSI/ANS 3.1-1987," "selection, Qualification and Training of Personnel for Nuclear Power Plants.")

I. ANSI/ANS 15.8-1976(R1986), "Quality Assurance Program Requirements for Research Reactors."

J. ANSI/ASME N45.2-1977, "Quality Assurance Program Requirements for Nuclear Facilities."

K. ANSI/ASME" N45.2.1-1973, "Cleaning of Fluid Systems and Associated Components During Construction Phase of Nuclear Power Plants." 
L. ANSI/ASME N45.2.6-1978, "Qualifications of Inspection, Examination and Testing Personnel for Nuclear Power Plants."

M. ANSI/ASME N45.2.12-1977, "Requirements for Auditing of Quality Assurance Programs for Nuclear Power Plants."

N. ANSI/ASME N45.2.13-1976, "Quality Assurance Requirements for Control of Procurement of Items and services for Nuclear Power Plants."

o. ANSI/ASME N45.2.23-1978, "Qualification of Quality Assurance Program. Audit Personnel for Nuclear Power Plants."

P. ANSI/ASME NQA-1-1986, "Quality Assurance Program Requirements for Nuclear Facilities."

Q. ANSI/ASME NQA-2-1986, "Quality Assurance Requirements for Nuclear Power Plants."

R. ANSI N45.2.4-1972/IEEE 336-1971, "Installation, Inspection, and Testing Requirements for Instrumentation and Electric Equipment During the Construction of Nuclear Power Generating stations." (This standard was revised and issued as ANSI/IEEE 336-1985, "IEEE Standard for Installation, Inspection, and Testing Requirements for Power, Instrumentation, and control Equipment at Nuclear Facilities.")

S. ANSI/IEEE 336-1985, "IEEE Standard for Installation, Inspection, and Testing Requirements for power, Instrumentation, and Control Equipment at Nuclear Facilities."

T. ANSI/IEEE 498-1980, "IEEE Standard Requirements for the calibration and Control of Measuring and Test Equipment Used in Nuclear Facilities." (This standard was revised and issued as ANSI/IEEE 498-1985, "IEEE standard Requirements for the Calibration and control of Measuring and Test Equipment Used in Nuclear Facilities.")

U. IEEE 467-1980, "IEEE Standard Quality Assurance Program Requirements for the Design and Manufacture of Class $1 \mathrm{E}$ Instrumentation and Electric Equipment for Nuclear Power Generating stations."

\subsection{4 supplemental Information}

A. NUREG-0800, USNRC Standard Review Plan, June 1987.

1. SRP 17.1, "Quality Assurance During the Design and Construction Phases." 
tion."

2. SRP 17.3, "Quality Assurance Program Descrip-

B. WASH 1309, "Guidance on Quality Assurance Requirements During the Construction Phase of Nuclear Power Plants," USAEC, MaY 1974.

C. WASH 1283; "Guidance on Quality Assurance Requirements During Design and Procurement Phase of Nuclear Power Plants," USAEC, May 1974.

D. IE Bulletin 79-14, Rev. 1, "Seismic Analysis for As-Built Safety-Related Piping Systems."

E. IE Information Notice 84-54, "Deficiencies in Design Base Documentation and Calculations supporting Nuclear Power Plant Design."

17.2 QUALITY ASSURANCE (QA) DURING THE OPERATIONS PHASE

17.2.1 Code of Federal Regulations

A. 10 CFR 50.34(b)(6)(ii), "Contents of Applications; Technical Information."

B. $\quad 10$ CFR 50.54, "Conditions of Licenses."

C. 10 CFR' 50.55, "Conditions of Construction Permits."

D. 10 CFR 50.55a, "Codes and Standards."

Reports."

E. 10 CFR 50.71, "Maintenance of Records, Making of

F. 10 CFR 50, Appendix A," "General Design Criteria for Nuclear Power Plants.".

G. 10 CFR 50, Appendix B; "Quality Assurance Criteria for Nuclear Power Plants and Fuel Reprocessing Plants."

17.2.2 USNRC Regulatory Guides BRP Branch Technical Positious and Appendices

A. Regulatory Guide 1.8 , "Qualification and Training of Personnel for Nuclear Power Plants."

B. Regulatory Guide 1.26 , "Quality Group Classifications, and Standards for Water-, steam-, and Radioactive-WasteContaining Components of Nuclear Power Plants." 
cation." C. Regulatory Guide 1.29, "Seismic Design Classifi-

D. Regulatory Guide 1.30, "Quality Assurance Requirements for the Installation, Inspection, and Testing of Instrumentation and Electric Equipment."

Requirements (Operation)."

E. Regulatory Guide 1.33, "Quality Assurance Program

F. Regulatory Guide 1.37, "Quality Assurance Requirements for Cleaning of Fluid Systems and Associated Components of Water-Cooled Nuclear Power Plants."

G. Regulatory Guide 1.38, "Quality Assurance Requirements for Packaging, Shipping, Receiving, storage, and Handling of Items for Water-Cooled Nuclear Power Plants."

H. Regulatory Guide 1.39, "Housekeeping Requirements for Water-Cooled Nuclear Power Plants."

I. Regulatory Guide 1.54, "Quality Assurance Requirements for Protective Coatings Applied to Water-Cooled Nuclear. Power Plants."

J. Regulatory Guide 1.58, "Qualification of Nuclear Power Plant Inspection, Examination, and Testing Personnel."

K. Regulatory Guide 1.64," "Quality Assurance Requirements for the Design of Nuclear Power Plants." and Definitions."

L. Regulatory Guide 1.74, "Quality Assurance Terms

M. Regulatory Guide 1.88, "Collection, Storage, and Maintenance of Nuclear Power Plant Quality Assurance Records."

N. Regulatory Guide 1.94, "Quality Assurance Requirements for Installation, Inspection, and Testing of Structural Concrete and structural steel During the Construction Phase of Nuclear Power Plants."

0. Regulatory Guide 1.116, "Quality Assurance Requirements for Installation, Inspection, and Testing of Mechanical Equipment and systems."

P. Regulatory Guide 1.123, "Quality Assurance Requirements for Control of Procurement of Items and Services for Nuclear Power Plants." 
Q. Regulatory Guide 1.143, "Design Guidance for Radioactive Waste Management systems, structures, and components Installed in Light-Water-Cooled Nuclear Power Plants."

R. Regulatory Guide 1.144, "Auditing of Quality Assurance Programs for Nuclear Power Plants."

S. Regulatory Guide 1.146, "Qualification of Quality Assurance Program Audit Personnel for Nuclear Power Plants."

T. Regulatory Guide 1.152, "Criteria for Programmable Digital Computer system software in safety-Related systems of Nuclear Power Plants."

U. Regulatory Guide 2.5, "Quality Assurance Program Requirements for Research Reactors."

V. Regulatory Guide 4.15, "Quality Assurance for Radiological Monitoring programs (Normal Operations) - Effluent Streams and the Environment."

W. SRP 9.5.1, Branch Technical Position CMEB 9.5-1, "Guidelines for Fire Protection for Nuclear Power Plants."

\subsubsection{Codes and standards}

Standards N45.2, N45.2.6, N45.2.9, N45.2.10, N45.2.12, N45.2.13 and N45.2.23 that are specified in NRC criteria and listed below were withdrawn and incorporated into ANSI/ASME NQA1-1986, "Quality. Assurance Program Requirements for Nuclear Facilities." Standards N45.2.1, N45.2.2, N45.2.3, N45.2.5 and N45.2.8 were withdrawn and incorporated into ANSI/ASME NQA-21986, "Quality Assurance Requirements for Nuclear Power Plants."

A. ANSI N45.2.2-1972, "Packaging, Shipping, Receiving, storage and Handling of Items for Nuclear Power Plants."

B. ANSI N45.2.3-1973, "Housekeeping During the Construction Phase of Nuclear Power Plants."

C. ANSI N45.2,4-1972/IEEE 336-1971, "Installation, Inspection, and "Testing Requirements for Instrumentation and Electric Equipment During the Construction of Nuclear Power Generating stations." (This standard was revised and issued as ANSI/IEEE 336-1985," "IEEE standard for Installation, Inspection, and Testing Requirements for Power, Instrumentation, and Control Equipment at Nuclear Facilities..")

D. ANSI N45.2.5-1974," "supplementary Quality Assurance Requirements for Installation, Inspection, and Testing of Structural concrete, structural steel, soils and Foundations During the construction Phase of Nuclear Power Plants." 
E. ANSI N45.2.8-1975, "supplementary Quality Assurance Requirements for Installation, Inspection and Testing of Mechanical Equipment and systems for the Construction Phase of Nuclear Power Plants."

F. ANSI N45.2.9-1974, "Requirements for Collection, Storage, and Maintenance of Quality Assurance Records for Nuclear Power Plants."

G. ANSI N45.2.10, "Quality Assurance Terms and
Definitions."

H. ANSI N45.2.11-1974, "Quality Assurance Requirements for the Design of Nuclear Power Plants."

I. ANSI/ANS 3.1-1981, "Selection, Qualification and Training of Personnel for Nuclear Power Plants." (This standard was revised and issued as ANSI/ANS 3.1-1987," "selection, Qualification and Training of Personnel for Nuclear Power Plants.")

J. ANSI/ANS 15.8-1976(R1986), "Quality Assurance Program Requirements for Research Reactors."

K. ANSI/ASME N45.2-1977, "Quality Assurance Program Requirements for Nuclear Facilities."

L. ANSI/ASME N45.2.1-1973," "Cleaning of Fluid systems and Associate Components During Construction Phase of Nuclear Power Plants."

M. ANSI/ASME N45.2.6-1978, "Qualifications of Inspection, Examination and Testing Personnel for Nuclear Power Plants."

N. ANSI/ASME N45.2.12-1977, "Requirements for Auditing of Quality Assurance Programs for Nuclear Power Plants."

O. ANSI/ASME N45.2.13-1976, "Quality Assurance Requirements for Control of Procurement of Items and Services for Nuclear Power, Plants."

P. ANSI/ASME N45.2.23-1978, "Qualification of Quality Assurance Program Audit Personnel for Nuclear Power Plants."

Q. ANSI/ASME NQA-1, 1986, "Quality Assurance Program Requirements for Nuclear Facilities."

R. ANSI/ASME NQA-2, 1986, "Quality Assurance Requirements for Nuclear Power Plants." 
S. ANSI/IEEE 336-1985, "IEEE standard for Installation, Inspection, and Testing Requirements for power, Instrumentation, and Control Equipment at Nuclear Facilities."

T. ANSI/IEEE 498-1980, "IEEE Standard Requirements for the Calibration and Control of Measuring and Test Equipment Used in Nuclear Facilities." (This standard was revised and issued as ANSI/IEEE 498-1985, "IEEE Standard Requirements for the Calibration and Control of Measuring and Test Equipment Used in Nuclear Facilities.")

U. ANS 3.2-1976, "Administrative Controls and Quality Assurance for the Operational Phase of Nuclear Power Plants." (This standard was revised and issued as ANSI/ANS 3.2-1982, "Administrative Controls and Quality Assurance for the Operational Phase of Nuclear Power Plants.")

V. ANSI/IEEE-ANS-7-4.3.2-1982, "Application Criteria for Programmable Digital Computer systems in safety systems of Nuclear Power Generating stations."

W. IEEE 467-1980, "IEEE standard Quality Assurance Program Requirements for the Design and Manufacture of Class $1 \mathrm{E}$ Instrumentation and Electric Equipment for Nuclear Power Generating stations."

\subsection{4 supplemental Information}

A. NUREG-0800, USNRC Standard Review Plan, June 1987. 1. SRP 17.2, "Quality Assurance During the Opertion." 2 SRP 17.3, "Quality Assurance Program Descrip-

B. NUREG/CR-5151, "Performance-Based Inspections."

c. WASH 1309, "Guidance on Quality Assurance Requirements During the construction. Phase of Nuclear Power Plants," USAEC, MaY 1974.

D. WASH 1284, "Guidance on Quality Assurance Requirements During the operations Phase of Nuclear Power Plants," USAEC, October 1973.

E. WASH 1283, "Guidance on Quality Assurance Requirements During Design and Procurement Phase of Nuclear Power Plants," USAEC, May 1974 . 
F. IE Information Notice 84-54, "Deficiencies in Design Base Documentation and Calculations supporting Nuclear Power Plant Design."

G. IE Information Notice 84-50, "Clarification of Scope of Quality Assurance Programs for Transport Packages Pursuant to 10 CFR 50 , Appendix B." 
CHAPTER 18

\section{HUMAN FACTORS ENGINEERING}

As a result of the TMI-2 accident, a chapter on human factors engineering was added to NUREG-0800, "standard Review Plan." Regulatory Guide 1.70 has not yet been revised to address this subject. This chapter identifies criteria for human factors engineering associated with the design of the control room and the safety parameter display system.

$18 \cdot 1$

CONTROL ROOM; DETAILED CONTROL ROOM DESIGN REVIEW (DCRDR)

This section identifies criteria for the design review of the control room and remote shutdown capability to assure the ability of reactor operators to prevent accidents and to cope with accidents if they occur.

\subsubsection{Code of Federal Regulations}

cal Information."

A. 10 CFR 50.34(f), "Contents of Applications; Techni-

B. 10 CFR 50, Appendix A, "General Design Criteria for Nuclear Power Plants."

1. GDC 19, "Control Room."

18.1.2 USNRC Regulatory Guides, SRP Branch Technical Positions and Appendices

A. Regulatory Guide 1.23, "Onsite Meteorological Programs."

B. Regulatory Guide 1.47, "Bypassed and Inoperable Status Indication for Nuclear Power Plant Safety Systems."

c. Regulatory Guide 1.97, "Instrumentation for Light-Water-Cooled Nuclear Power Plants to Assess Plant and Environs Conditions During and Following an Accident."

D. SRP 18.1, Appendix A, "Evaluation criteria for Detailed Control Room Design Reviews (DCRDR)."

\subsubsection{Codes and standards}

A. ANSI/IEEE 603-1980, "IEEE Standard Criteria for Safety systems for Nuclear Power Generating Stations." 
B. IEEE 279-1971, "Criteria for Protection systems for Nuclear Power Generating stations." (This standard was withdrawn on June 14, 1984 and incorporated into ANSI/IEEE 603-1980, "IEEE standard Criteria for Safety systems for Nuclear Power Generating stations.")

\subsection{4 supplementary Information} September 1984 .

A. NUREG-0800, USNRC "Standard Review Plan," Rev. 1,

$$
\text { 1. SRP 18.1, "Control Room." }
$$

B. NUREG-0737, Supplement 1, "Requirements for Emergency Response Capability," USNRC, January 1983.

C. NUREG-0899, "Guidelines for the Preparation of Emergency operating Procedures - Resolution of Comments on NUREG0799," USNRC, August 1982

D. NUREG-0835, "Human Factors Acceptance criteria for Safety Parameter Display System," USNRC, October 1981.

E. NUREG-0700, "Guidelines for Control Room Design Reviews," USNRC, September 1981.

F. NUREG-0799, "Draft Criteria for Preparation of Emergency Operating Procedures," USNRC, June 1981.

G. NUREG-0696, "Functional Criteria for Emergency Response Facilities," USNRC, February 1981.

H. NUREG-0654/FEMA-REP-1 (Rev. 1), "Criteria for Preparation and Evaluation of Radiological Emergency Response Plans and Preparedness in support of Nuclear Power Plants," USNRC, November 1980 .

I. NUREG-0737, "Clarification of TMI Action Plan Requirements," USNRC, November 1980 .

J. NUREG-0660, (Rev. 1), "NRC Action Plan Developed as a Result of the TMI-2 ACCident," Item I.D.1, "Control Room Design Reviews," USNRC, August 1980.

K. NUREG-0585, "TMI-2 Lessons Learned Task Force," USNRC, October 1979 .

L. EPRI Report NP-2411, "Human Engineering Guide for Enhancing Nuclear Control Rooms," Electric Power Research Institute, May 1982. 
Reports:

M. Nuclear Utility Task Action Committee (NUTAC)

1. INPO 83-047 (NUTAC), "Component Verification and system Validation Guideline," Institute of Nuclear Power Operations/CRDR NUTAC, December 1983.

2. INPO 83-046 (NUTAC), "Control Room Design Review Task Analysis Guideline," Institute of Nuclear Power Operations/CRDR NUTAC, December 1983.

3. INPO 83-042 (NUTAC); "Control Room Design Review Survey Development Guideline," Institute of Nuclear Power operations/CRDR NUTAC, November 1983.

5. INPO 83-026 (NUTAC), "Control Room Design Review Implementation Guideline," Institute of Nuclear Power Operations/CRDR NUTAC, July 1983.

4. INPO 83-036 (NUTAC), "Human Engineering Principles for Control Room Design Review, "Institute of Nuclear Power Operations/CRDR NUTAC, September 1983.

\subsection{SAFETY PARAMETER DISPLAY SYBTEM (SPDS)}

This section identifies criteria for the review of human engineering principles applied to the SPDS review of the verification and validation program relating to spDs design, testing, human performance aspects, hardware and software quality, and parameter displays, and review of the adequacy and basis of the parameters selected for display to represent critical plant functions.

\subsubsection{Code of Federal Regulations}

cal Information."

A. 10 CFR $50.34(f)$, "Contents of Application; Techni-

B. 10 CFR 50, Appendix A, "General Design Criteria for Nuclear Power Plants."

$$
\text { 1. GDC'19, "Control room." }
$$

\subsubsection{USNRC Regulatory Guides, sRP Branch Technical Positions and Appendices}

A. Regulatory Güide 1:97, "Instrumentation for Light-water-Cooled Nuclear Power Plants to Assess Plant and Environs Conditions During and Following an Accident." 
B. SRP 18.1, Appendix A, "Evaluation criteria for Detailed Control Room Design Reviews (DCRDR)."

C. SRP 18.2, Appendix A, "Human Factors Review Guidelines for the Safety parameter Display System (SPDS)."

18.2.3 Codes and standards

None.

\subsubsection{Supplemental Information} September 1984 .

A. NUREG-0800, USNRC" "Standard Review Plan," Rev. 1, (SPDS)."

1. SRP 18.1, "Control Room."

2. SRP 18.2, "Safety Parameter Display System

B. NUREG-0737, Supplement 1, "Requirements for Emergency Response Capability," USNRC, January 1983.

C. NUREG-0835, "Human Factors Acceptance Criteria for Safety Parameter Display System," USNRC, October 1981.

D. NUREG-0700, "Guidelines for Control Room Design Reviews," USNRC, September 1981. (This was originally issued as NUREG/CR-1580.)

E. NUREG-0696, "Functional Criteria for Emergency Response Facilities," USNRC, February 1981.

F. NUREG-0737, "Clarification of TMI Action Plan Requirements," USNRC, November 1980:

G. NUREG-0660 (Rev, 1), "NRC Action Plan Developed as a Result of the TMI-2 Accident," Item I.D.2, "Plant Safety Parameter Display Console," USNRC, August 1980.

H. INPO 83-003 (NUTAC), "Guidelines for an Effective Safety Parameter Display system (SPDS) Implementation Program," Institute of Nuclear Power operations/SPDS Nuclear Utility Task Action Committee, January 1983.

I. NSAC 39, "Verification and Validation of safety Variable Display Systems," Nuclear Safety Analysis Center, December 1981 . 
J. EPRI Report NP-1118, Vol. 4, "Human Factors Considerations for Advanced Control Board Design," J.L. Seminara and S.K. Eckert, Electric Power Research Institute, March 1980. 